\title{
PROFESSIONAL RESTRAINTS ON INNOVATION IN HEALTH CARE FINANCING*
}

\author{
Clark C. Havighurst**
}

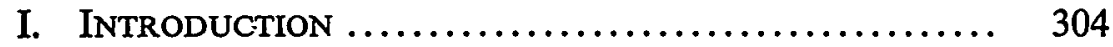

II. AN Overview of the Medical Profession's Methods of Resisting Change ................ 306

A. The Strong Arm and the Heavy Hand: Boycotts and Related Restraints.......................... 307

B. The Strategy of Preemption and Cooptation:

Professionally Sponsored Reforms............... 313

C. Recent Exertions of Professional Power.......... 316

III. Assessing the Public Significance of Professional Restraints on THIRd-PARTy PAYers ............. 319

A. Neglected Private Cost-Containment Strategies..... 321

1. Some Possible Insurer Strategies ........... 321

2. Enlisting Physician Cooperation: Provider

Panels ................................. 326

* Work on this Article was supported by Grant No. HS01539 from the National Center for Health Services Research, U.S. Department of Health, Education and Welfare. Portions are an expansion of an earlier work: Havighurst, The Role of Competition in Cost Containment, in FEDeral Trade Commission, Competition in the Health Care Sector: Past, Present, and FUTURE 359 (1978).

** Professor of Law and Director, Program on Legal Issues in Health Care, Duke University.

THE FOLLOWING CITATIONS WILL BE USED IN THIS ARTICLE:

Council on Wage and Price Stability, Executive Office of the President, The Complex Puzzle of Rising health Care Costs: Can the Private Sector Fit it ToGETHER? (1977) [hereinafter cited as CouncIL on WAGe \& PRICE STABility];

Enthoven, Consumer-Choice Health Plan (pts. 1 \& 2), 298 NEw ENG. J. MED. 650, 709 (1978) [hereinafter cited as Enthoven];

Federal Trade Commission, Competition in the Health Care Sector: Past, PresENT, AND FUTURE (1978) [hereinafter cited as FTC];

Goldberg \& Greenberg, The Effect of Physician-Controlled Health Insurance. U.S. v. Oregon State Medical Society, 2 J. HEALTH PoL., POL'Y \& L. 48 (1977) [hereinafter cited as Goldberg \& Greenberg];

Havighurst, Controlling Health Care Costs: Strengthening the Private Sector's Hand, 1 J. Health Pol., Pol'y \& L. 471 (1977) [hereinafter cited as Controlling Health Care Costs];

Havighurst \& Blumstein, Coping with Quality/Cost Trade-Offs in Medical Care: The Role of PSROS, 70 Nw. U.L. REv. 6 (1975) [hereinafter cited as Havighurst \& Blumstein];

Kallstrom, Health Care Cost Control by Third Party Payors: Fee Schedules and the Sherman $A c t, 1978$ DuKe L.J. 645 [hereinafter cited as Kallstrom]. 


\section{The Attractions of Private Measures to Control} Costs .................................. 334

B. Other Unfavorable Factors in the Climate for Private Cost Containment ............................... $\quad 336$

1. The Third-Party Payers................... 336

2. The Customers: The Weakness of Demand for Cost Containment........................ $\quad 342$

IV. ANTITRUSt Remedies fOR Professional Restraints.. 343

A. Professional Boycotts ........................ 344

1. Proving a Conspiracy to Boycott .............. 344

2. Professionalism as a Defense for Boycotts....... 349

B. Practices Conducive to Boycotts ................. 354

1. Applying the Boycott Label .................. 354

2. Confronting the "Free Speech" Argument: The Noerr-Pennington Doctrine.................. 355

3. The "Seal-of-Approval" Analogy ............. 360

C. Professional Self-Discipline ..................... 362

1. Applying the Rule of Reason ................. 362

2. Antitrust's Impact on Specific Mechanisms of SelfDiscipline................................. 365

D. The Efficacy of Antitrust for Combatting Subtle Restraints ................................... 368

1. Clarifying the Law ..................... 369

2. Assessing the Prospects for Innovation Under an Antitrust Regime ........................ 373

V. The Antitrust Status of the Profession's OwN "REFORMS" .................................... 374

A. Professionally Sponsored Prepayment Plans ......... 375

B. Professionally Sponsored Cost Containment ......... 377

C. The Medical Societies as Collective Bargainers....... 381

VI. Conclusion ................................. 384

\section{INTRODUCTION}

Recent escalation of health care costs in the United States has inspired a rapid expansion of regulatory controls over the health services industry. But governmental efforts to grapple with costs directly through regulation have reflected a concern for a symptom of the health care system's underlying problems rather than a desire to find and address root causes. ${ }^{1}$ The thesis of this Article is that one impor-

1. This Article continues an exploration of the relative value of regulation and market forces in finding the appropriate level of health care spending. On regulatory issues, see Havighurst, 
tant, and probably remediable, cause of the cost crisis has been the medical profession's long-standing resistance to economizing innovations in the organization and administration of private plans for financing health care. It is argued that vigorous enforcement of the antitrust laws against certain concerted actions taken by physicians with respect to health care financing could significantly improve the climate for private cost-containment initiatives. New interest by the antitrust enforcement agencies in the activities of the organized professions and in the health services industry generally ${ }^{2}$ suggests the existence of real prospects for expanding opportunities for privately initiated change.

Organized medicine has always attached great importance to health care financing mechanisms and the behavior of private thirdparty payers for medical care. Despite the obstacles that the profession has placed in the way of financing plans employing cost-containment strategies, health maintenance organizations (HMOs) have become established in some communities as an alternative to traditional financing mechanisms. However, professional opposition to HMOs has remained strong in many places, and HMOs have not developed rapidly or widely. ${ }^{3}$ Less well recognized than the medical profession's success in curbing HMO development has been its effectiveness in discouraging structural and administrative innovations in traditional insurance and service-benefit plans. The result of the profession's efforts in this area has been to deny consumers access to third-party payment plans. These plans would serve consumers' interest in economizing, either by strengthening their bargaining position vis-a-vis

Health Care Cost-Containment Regulation: Prospects and an Alternative, 3 AM. J. L. \& MED. 309 (1977); Havighurst, Federal Regulation of the Health Care Delivery System: A Foreword in the Nature of a "Package Insert," 6 U. ToL. L. REv. 577 (1975); Havighurst, Regulation of Health Facilities and Services by "Certificate of Need," 59 VA. L. Rev. 1143 (1973); Havighurst \& Blumstein; Havighurst \& Bovbjerg, Professional Standards Review Organizations and Health Maintenance Organizations: Are They Compatible?, 1975 UTAH L. REv. 381. On the market alternative, see Controlling Health Care Costs, Havighurst, Health Maintenance Organizations and the Market for Health Services, 35 LAw \& CONTEMP. PROB. 716 (1970); Havighurst, Speculations on the Market's Future in Health Care, in Regulating Health Facilities Construction 249 (C. Havighurst ed. 1974); Havighurst, Blumstein \& Bovbjerg, Strategies in Underwriting the Costs of Catastrophic Disease, 40 LAw \& CONTEMP. PROB. 122 (1976). The thesis developed in these writings is that the prospects for effective regulation are overestimated and that the market's potential value is underestimated. The skepticism toward regulatory prescriptions is comparable to that appearing in C. Schultze, The Public Use of Private Interest (1977) (a recent and widely noted book by the current chairman of the President's Council of Economic Advisors).

2. See, e.g., Antitrust: New Pressures on Medicine, PAtient CARe, Jan. 15, 1978, at 38. The Federal Trade Commission has been somewhat more active in this area than the Department of Justice.

3. See generally Kissam, Health Maintenance Organizations and the Role of Antitrust Laws 1978 Duke L.J. 487. 
providers' monopoly power or by preventing doctors and patients from spending inappropriately the funds contributed to the insurance pool.

Although the medical profession's professed reason for inhibiting the development of HMOs and other health care plans with effective cost-containment features has been the preservation of the "quality of care," "free choice of physician," the "doctor-patient relationship," and "professional independence," the physicians' concerted efforts have had a darker side as well. The financing programs that have been acceptable to the medical profession have systematically fostered the demand-stimulating effects of third-party payment and foreclosed experimentation with ways of offsetting those effects. The profession has particularly resisted attempts to alter the fee-for-service mode of payment, to create closed panels of physicians as competitive alternatives to traditional "free choice" insurance plans, and to impose direct or indirect administrative checks on decision making by physicians and patients affecting the expenditure of insurance funds. In addition to HMOs founded on the prepaid group practice model, ${ }^{4}$ there is a largely unexplored spectrum of possible administrative arrangements lying between such HMOs at one extreme and traditional forms of health insurance at the other. One purpose of this Article is to highlight some of the points on this spectrum that deserve more attention than they have received.

In addition to examining professional restraints on the growth of such recognized innovations as HMOs, this Article seeks to establish the true importance of the de facto disciplinary power exercised by organized medicine over third-party payers for medical care, not only in the past but at the present time. While other factors also contribute to the underdevelopment of cost-containment capabilities in the private sector, it is argued that the slow pace of meaningful change in this area would increase significantly if third-party payers were less deferential toward the medical profession. The second half of the Article is concerned specifically with the potential utility of the antitrust laws to reduce the threat posed by organized medicine to innovation in health care financing.

\section{An Overview of the Medical Profession's Methods of Resisting Change}

As a result of their long enjoyment of substantial professional au-

4. See, e.g., Phelan, Erickson \& Fleming, Group Practice Prepayment: An Approach to Delivering Organized Health Services, 35 LAW \& CONTEMP. PROB. 796 (1970). 
tonomy, ${ }^{5}$ physicians now respond almost reflexively to outside interference in their affairs by taking collective action through their local, state and national professional associations, through hospital staff organizations, and through less formal mechanisms. But as "combinations" of competitors, professional groups must be prepared to defend themselves against the charge under federal or state antitrust laws ${ }^{6}$ that their various activities unreasonably restrict competition and deny consumers the benefits of a functioning market. Although courts may allow professional groups some leeway not allowed industrial trade associations, ${ }^{7}$ there are certain practices, not all of them uncommon, that can be called into question. Before addressing the social significance of these restraints or the antitrust issues they present, it is useful to describe the means that have been employed by doctors to resist unwanted measures.

\section{A. The Strong Arm and the Heavy Hand: Boycotts and Related Restraints.}

Early professional efforts at repressing unwanted innovations primarily involved the use of ethical rules to deny professional opportunities to physicians who cooperated with new plans. As revealed in the 1943 antitrust case of American Medical Association v. United States, ${ }^{8}$ expulsion from membership in the county medical society for ethical violations was an effective tactic against Group Health Association, an $\mathrm{HMO}$, because hospital staff privileges were not generally available to HMO physicians without such membership. ${ }^{9}$ This precondition for staff membership resulted in part from the AMA's "Mundt Resolu-

5. Sociologists have shown considerable interest in the autonomy that society has seemingly granted the so-called learned professions. See, e.g., J. Berlant, Profession and Monopoly: A Study of Medicine in the United States and Great Britain (1975); E. Freidson, Professional Dominance: The Social Structure of Medical Care (1970).

6. Section 1 of the Sherman Act, 15 U.S.C. $\$ 1$ (1976), provides that "[e]very contract, combination . . . or conspiracy, in restraint of trade or commerce among the several States, . . . is declared to be illegal." The other principal federal antitrust statutes are the Clayton Act, 15 U.S.C. $\S \S 12-27$ (1976), and the Federal Trade Commission Act, 15 U.S.C. $\$ \S 41-58$ (1976). Many of the state antitrust laws are patterned after the federal statutes. See, e.g., N.C. GEN. STAT. § 75-1 (1975).

7. See notes 197, 199 infra and text accompanying notes 197-99 infra.

8. 130 F.2d 233 (D.C. Cir. 1942), affd, 317 U.S. 519 (1943).

9. Offending physicians were expelled or threatened with expulsion for violation of the ethic against "contract practice" of medicine. 130 F.2d at 238-39 n.23. A strikingly similar case is Group Health Coop. v. King County Medical Soc'y, 39 Wash. 2d 586, 237 P.2d 737 (1951).

Other doctors involved in HMOs have also encountered problems in obtaining or keeping membership in local medical societies. For example, in Elk City, Oklahoma, after harassing but not finding any reason to expel the director of a prepaid medical plan, the local medical society dissolved for six months and reorganized without him. See E. RAYACK, Professional Power and American Medicine: The Economics of the American Medical Assoclation 181 
tion," which stated that internship programs would not be authorized by the AMA in hospitals where all staff members were not members of the local medical society. ${ }^{10}$ Power over accreditation of educational programs was thus parlayed into control of hospital policies and ultimately into control over all physicians requiring access to a high-quality hospital. ${ }^{11}$

Today hospital privileges are no longer as likely to be directly tied to medical society membership. ${ }^{12}$ But other professional and social benefits that flow from society membership ${ }^{13}$ may still be such that the possibility of nonadmission or expulsion can keep unorthodoxy from spreading in a medical community. Although increasing judicial willingness to review arbitrary membership policies under common law principles governing voluntary associations ${ }^{14}$ may have reduced the

(1967). Ethical grounds were cited for excluding doctors participating in the Health Insurance Plan of Greater New York from the local medical society. Id. 189.

10. 130 F.2d at 250 n.87.

11. The low pay of interns at that time gave hospitals a strong incentive to meet the AMA's requirements. The AMA actively enforced the Mundt Resolution, sending letters to the hospitals inquiring as to their compliance. Id. at n.89.

12. For a case striking down a requirement of medical society membership as a condition of staff privileges, see Greisman v. Newcomb Hosp., 40 N.J. 389, 192 A.2d 817 (1963). A case indicating that ties between society membership and staff privileges still exist is Maricopa County Medical Soc'y v. Blende, 104 Ariz. 12, 448 P. $2 d 68$ (1968). For other examples, see Rayack, The Physicians' Service Industry, in THE STRUCTURe of AMERICAN INDUSTRY 419 (W. Adams ed. 1971).

13. Cf. Boddicker v. Arizona State Dental Ass'n, 549 F.2d 626, 628-29 (9th Cir.), cert. denied, 434 U.S. 825 (1977) (reviewing benefits of dental society membership). Membership in or certification by a specialty society or board has particular value as a professional distinction. $C$. Pinsker v. Pacific Coast Soc'y of Orthodontists, I Cal. 3d 160, 460 P.2d 495, 81 Cal. Rptr. 623 (1969) (membership in orthodontic association not an "economic necessity" but denial of membership held harmful nevertheless). See also United States Dental Inst. v. American Ass'n of Orthodontists, 1977-2 Trade Cases I 61,557; United States Dental Inst. v. American Ass'n of Orthodontists, 396 F. Supp. 565 (N.D. Ill. 1975). For a case in which pathologists used their power to certify medical technologists to disadvantage competing clinical laboratories, see Higgins v. American Soc'y of Clinical Pathologists, 51 N.J. 191, 238 A.2d 665 (1968), appeal after remand, 53 N.J. 547, 251 A.2d 760 (1969).

14. See Maricopa County Medical Soc'y v. Blende, 104 Ariz. 12, 448 P.2d 68 (1968); Pinsker v. Pacific Coast Soc'y of Orthodontists, 12 Cal. 3d 541, 526 P.2d 253, 116 Cal. Rptr. 245 (1974); Pinsker v. Pacific Coast Soc'y of Orthodontists, 1 Cal. 3d 160, 460 P.2d 495, 81 Cal. Rptr. 623 (1969); Bernstein v. Alameda-Contra Costa Medical Ass'n, 139 Cal. App. 2d 241, 293 P.2d 862 (1956). For earlier cases taking a narrower view, see Elizabeth Hosp., Inc. v. Richardson, 167 F. Supp. 155, 164 (W.D. Ark.), aff'd, 269 F.2d 167 (8th Cir. 1958), cert. denied, 361 U.S. 884 (1959); Smith v. Kern County Medical Ass'n, 19 Cal. 2d 263, 120 P.2d 874 (1942); Porter v. King County Medical Soc'y, 186 Wash. 410, 58 P.2d 367 (1936). As stated in the Pinsker cases, where the court finds that the professional society occupies such a unique position in the profession that exclusion from membership deprives the plaintiff of substantial economic advantages, a public interest is shown and the court will review the society's membership policies both for their substantive rationality and for their accordance with basic due process. 12 Cal. 3d at 543-45, 526 P.2d at 255-56, 116 Cal. Rptr. at 247-48; 1 Cal. 3d at 165-67, 460 P.2d at 498-99, 81 Cal. Rptr. at 626-27. 
medical societies' powers of intimidation, the societies still possess a range of discretion in formulating and enforcing ethical and qualityrelated standards ${ }^{15}$ that threaten individual practitioners experimenting with lower-cost approaches to medical care. As long as a medical society proceeds under the banner of the quality of care, professionalism, ethics, or patients' rights, it may be able to isolate many types of innovators, raise their costs, diminish their prospects and perhaps discredit them to the point where they will fail. . $^{16}$

Access to a hospital is essential to most physicians, ${ }^{17}$ and for that reason control over admitting privileges is probably the most powerful weapon in enforcing the preferences of the professional majority. Because of the technical questions necessarily involved, hospital boards must delegate the administration of staff privileges to professionals. The universal practice is for the staff physicians, who are competitors in the market for medical services, to organize formally to perform this and other peer-review functions. ${ }^{18}$ Thus, the hospital, by bringing physicians together on a regular basis and according them the power to control the availability of an important resource, is an ideal vehicle for controlling medical practice in a community. ${ }^{19}$ Even in areas where several hospitals exist, the medical staffs of each are likely to reflect the

15. See, e.g., Pinsker v. Pacific Coast Soc'y of Orthodontists, 12 Cal. 3d 541, 558-60, 526 P.2d 253, 266-67, 116 Cal. Rptr. 245, 258-59 (1974) (specialty dental society allowed to maintain rule against delegation of tasks to uncertified dentists); Cal-Medicon v. Los Angeles County Medical Ass'n, 20 Cal. App. 3d 148, 152-53, 97 Cal. Rptr. 530, 533 (1971) (protection of interests of its members and the public held to justify association's interference with its members' participation in plaintiff's referral business).

16. For examples of alleged professional society harassment of innovative plans in the name of professional values, see Health Corp. of America, Inc. v. New Jersey Dental Ass'n, 424 F. Supp. 931 (D.C.N.J. 1977) (threats, harassment, coercion and the dissemination of misinformation allegedly used by dental societies to induce dentists not to contract with prepaid dental plan); CalMedicon v. Los Angeles County Medical Ass'n, 20 Cal. App. 3d 148, 97 Cal. Rptr. 530 (1971).

17. Guerrero v. Burlington County Memorial Hosp., 70 N.J. 344, 355, 360 A.2d 334, 339 (1976).

18. See text accompanying note 23 infra.

19. Cases revealing use of the privilege system to discourage competitive innovation include American Medical Ass'n v. United States, 317 U.S. 519 (1943); Sams v. Ohio Valley Gen. Hosp. Ass'n, 413 F.2d 826 (4th Cir. 1969) (place-of-business requirement held unreasonable; plaintiffs were HMO practitioners); Feminist Women's Health Center, Inc. v. Mohammad, 415 F. Supp. 1258 (N.D. Fla. 1976); Group Health Coop. v. King County Medical Soc'y, 39 Wash. 2d 586, 237 P.2d 737 (1951). See also Ascherman v. San Francisco Medical Soc'y, 39 Cal. App. 3d 623, 114 Cal. Rptr. 681 (1974) (political activities of plaintiff-physician resulted in loss of privileges at three hospitals). On the exclusion of osteopaths, see Wolf v. Jane Phillips Episcopal-Memorial Medical Center, 513 F.2d 684 (10th Cir. 1975); Greisman v. Newcomb Hosp., 40 N.J. 389, 192 A.2d 817 (1963); E. RAYACK, supra note 9, at 244-45; Blackstone, The A.M.A. and the Osteopaths: $A$ Study of the Power of Organized Medicine, 22 ANTITRUST Bull. 405, $411-14$ (1977). On podiatrists' access to hospital privileges, see Levin v. Doctors Hosp., Inc., 223 F. Supp. 953 (D.D.C. 1964), rev'd sub nom. Levin v. Joint Comm'n on Accreditation of Hosps., 354 F.2d 515 (D.C. Cir. 1965). 
dominant professional interests and ideology. Moreover, hospital boards which might be tempted to compete for patients by catering to an innovative provider, such as an HMO, face a risk that, if offended, their staff doctors will send their patients elsewhere. ${ }^{20}$

Because of the influence of medical staffs over hospital decisions on staff privileges and on other matters potentially affecting innovation, neither public nor private hospitals should be seen as independent decisionmakers whose discretion is unreviewable. ${ }^{21}$ In recent years there has been an increase in judicial scrutiny of staff membership decisions. ${ }^{22}$ Further, procedures for granting, withholding, or curtailing privileges have been regularized as a result of pressure from the Joint Commission on the Accreditation of Hospitals, ${ }^{23}$ thus reducing the potential for anticompetitive abuse. Once again, however, the myriad opportunities for questioning the ethics and competence of providers engaged in activities threatening to dominant professional interests remain such that the power to withhold staff privileges may be used effectively to curb change. ${ }^{24}$ One would suppose that only a minority of professionals would feel completely secure in subjecting themselves to the special scrutiny that deviation from accepted patterns could be expected to occasion. ${ }^{25}$

20. See, e.g., Competition in the Health Services Market: Hearings Before the Subcomm. on Antitrust and Monopoly of the Senate Comm. on the Judiciary, 93d Cong., 2d Sess. 1567-68 (1974) (statement of John W. Riley).

21. Public hospitals must meet constitutional due process requirements which are inapplicable to private hospitals without a finding of "state action." See, e.g., Foster v. Mobile County Hosp. Bd., 398 F.2d 277 (5th Cir. 1968); Cypress v. Newport News Gen. \& Nonsectarian Hosp. Ass'n, 375 F.2d 648 (4th Cir. 1967); Wyatt v. Tahoe Forest Hosp. Dist., 174 Cal. App. 2d 709, 345 P.2d 93 (1959). Private hospitals, however, are increasingly subject to comparable requirements as a matter of common law. See cases cited in note 22 infra. Factual situations involving decisions by the institution itself and not presenting the conflict of interests implicit in decisions by the medical staff may be treated differently, with greater discretion allowed. See Guerrero v. Burlington County Memorial Hosp., 70 N.J. 344, 360 A.2d 334 (1976); Davis v. Morristown Memorial Hosp., 106 N.J. Super. 33, 254 A.2d 125 (1969); Fried v. Straussman, 41 N.Y. 2d 376, 393 N.Y.S.2d 334, 361 N.E.2d 984 (1977).

22. See, e.g., Ascherman v. San Francisco Medical Soc'y, 39 Cal. App. 3d 623, 114 Cal. Rptr. 681 (1974); Greisman v. Newcomb Hosp. 40 N.J. 389, 192 A.2d 817 (1963); Annot., 37 A.L.R.3d 645 (1971). But see, e.g., Sosa v. Board of Managers of Val Verde Memorial Hosp., 437 F.2d 173 (5th Cir. 1971); Lloyd v. Jefferson Davis Memorial Hosp., 345 So. 2d 1046 (Miss. 1977); Grodjesk v. Jersey City Medical Center, 135 N.J. Super. 393, 343 A.2d 489 (1975).

23. See JoInt COMm'N ON ACCREditation of Hospitals, Accreditation Manual for JCAH Hospitals $46-48$ (1973).

24. Cases recognizing broad medical staff discretion in setting and enforcing standards include Klinge v. Lutheran Charities Ass'n, 523 F.2d 56 (8th Cir. 1975); Woodbury v. McKinnan, 447 F.2d 839 (5th Cir. 1971); Sosa v. Board of Managers of Val Verde Memorial Hosp., 437 F.2d 173 (5th Cir. 1971); Moore v. Board of Carson-Tahoe Hosp., 88 Nev. 207, 495 P.2d 605, cert. denied, 409 U.S. 879 (1972).

25. Selective enforcement of standards against unorthodox physicians is a particular risk. $C f$. 
The increase in specialization in medicine, ${ }^{26}$ by increasing interdependence among physicians, has also provided a powerful weapon for controlling unorthodox forms of health care delivery. ${ }^{27}$ Thus, a specialist cooperating with an HMO or other innovative program may jeopardize the referrals from other physicians on which his practice depends, and specialists opposed to the HMO may refuse to consult with HMO physicians referring patients to them. ${ }^{28}$ Moreover, organized medicine's efforts to encourage such responses could significantly increase the magnitude of the problem. In the $A M A$ case, for example, the circulation of a "white list" of approved providers served not only as a "seal of approval" but also as an invitation to boycott those providers who were omitted from the list. ${ }^{29}$ Indeed, mere association with such providers raised ethical questions, and one specialist was challenged for accepting a Group Health check after treating a referred patient. ${ }^{30}$ Even without an identifiable call for a boycott, however, a fall-off in a specialist's referrals or an increase in noncooperation with referring physicians could easily occur. Not only does the apparent legitimacy of the profession's concerns over ethics or quality make legal control difficult, but the profession's communications network is difficult to monitor for clues as to the doctors' true purposes. ${ }^{31}$

Exclusion of a physician from a profession-dominated financing plan, such as Blue Shield ${ }^{32}$ or a county medical service bureau, ${ }^{33}$ has also been used to good effect in combatting innovation and competi-

Woodbury v. McKinnan, 447 F.2d 839 (5th Cir. 1971) (physician denied right to challenge the competence of staff members).

26. See generally R. Stevens, American Medicine and the Public Interest (1971).

27. In Feminist Women's Health Center v. Mohammad, 415 F. Supp. 1258 (N.D. Fla. 1976), a physician who had worked in an abortion clinic objectionable to competing physicians was alleged to have experienced a delay in obtaining specialty board certification. See Brief for Plaintiff-Appellant on appeal to the United States Court of Appeals for the Fifth Circuit at 23.

28. Cases revealing abuses of the referral process include Ascherman v. San Francisco Medical Soc'y, 39 Cal. App. 3d 623, 114 Cal. Rptr. 681 (1974) (plaintiff ceased receiving referrals from society's answering service); Hubbard v. Medical Serv. Corp., 59 Wash. 2d 449, 367 P.2d 1003 (1962) (enjoining practice of preventing referral of nonsubscriber to nonmedical society bureau doctor); Group Health Coop. v. King County Medical Soc'y, 39 Wash. 2d 586, 237 P.2d 737 (1951). Refusals by medical doctors to consult with osteopaths are discussed in Blackstone, supra note 19 , at 416-17.

29. See United States v. American Medical Ass'n, 110 F.2d 703, 706-07 (D.C. Cir.), cert. denied, 310 U.S. 644 (1940). See also text accompanying notes 234-39 infra.

30. American Medical Ass'n v. United States, 130 F.2d 233, 238 n.23 (D.C. Cir. 1942).

31. Letters and statements in the record in the $A M A$ case, however, made the doctors' purposes clear. Similarly, in Feminist Women's Health Center, Inc. v. Mohammad, 415 F. Supp. 1258 (N.D. Fla. 1976), statements by one of the defendants made it obvious that a boycott of a local abortion clinic was economically motivated. $I d$. at 1266 . Such evidence will not often be available.

32. On Blue Shield, see notes 46, 50, 56-59, 61, 280, 282, 285, 287-290, 292, 295, 296, 298-301, 304 infra and text accompanying notes 46-61, 279-307 infra.

33. See Hearings, supra note 20 , at 1564 . 
tion. ${ }^{34}$ Some service bureaus have had exclusive dealing clauses in their contracts with participating physicians which prevented them from becoming involved with HMOs. ${ }^{35}$ This tactic effectively prevents the physician accepting HMOs' referrals from serving the financing plan's subscribers; in the absence of alternative financing plans or a full-time HMO practice, the effect on the physician is catastrophic. ${ }^{36}$

Another way to frustrate an innovative health plan is to make it inconvenient for the patient who enrolls with the plan. In the $A M A$ case, the doctors refused to accept Group Health's checks in payment for services rendered to Group Health subscribers on referral. ${ }^{37}$ Instead, patients were required to pay personally and obtain reimbursement from Group Health. Similarly, in United States v. Oregon State Medical Society, ${ }^{38}$ physicians refused to deal with the objectionable "hospital associations," refusing to submit to the plans' attempted cost controls and insisting that they confine themselves to indemnifying patients for incurred costs. Although physicians and hospitals will usually deal directly with indemnity insurers as an accommodation to their patients, their ability to cease doing so is a powerful disciplinary weapon. Likewise, medical service plans, such as Blue Shield, and other plans dependent on contractual relationships with providers are susceptible to refusals to sign participation agreements. In either case, concerted refusals to deal are a significant danger because of professional solidarity, which flows in part from the interrelationships detailed above and individual practitioners' vulnerability to pressure.

The foregoing powers of organized medicine over physicians and third parties are formidable enough that they need not be exercised frequently or fully to achieve the desired results. To control a physician's behavior, for example, it would usually be sufficient just to raise a question concerning its propriety. ${ }^{39}$ Even where the formal power to discipline a physician is lacking or there is no credible threat to invoke

34. See Ballard v. Blue Shield of S. West Virginia, Inc., 543 F.2d 1075 (4th Cir. 1976), cert. denied, 430 U.S. 922 (1977) (exclusion of chiropractors); Medical Serv. Corp., [1977] TRADE Rea. REP. (CCH) I 21,195 (FTC Dkt. No. C-2853, Dec. 3, 1976) (exclusion of HMO doctors); Group Health Coop. v. King County Medical Soc'y, 39 Wash. 2d 586, 237 P.2d 737 (1951); Hearings, supra note 20, at 1562-96.

35. See Hearings, supra note 20, at 1615-20 (exhibit: Treatise by L.S. Helland).

36. For a discussion of the very different issues presented by the exclusion of providers from financing plans not dominated by professional interests, see text accompanying notes 105-33 infro.

37. Record 611-12, American Medical Ass'n v. United States, 317 U.S. 519 (1943).

38. 343 U.S. 326 (1952). See Goldberg \& Greenberg 51-53.

39. A recent illustration is provided by Feminist Women's Health Center, Inc. v. Mohammad, 415 F. Supp. 1258 (N.D. Fla. 1976), in which the obstetrics-gynecology staff of a community hospital induced staff physicians to sever their connections with a local competing abortion clinic simply by questioning the clinic's ethics and quality of care. 
such power, a fear of jeopardizing professional and social relations may inhibit the behavior of many doctors. ${ }^{40}$ Then, when innovative programs are forced to rely primarily on the medical profession's outsiders-foreign medical graduates, osteopaths, and others not full-fledged members of the club-the profession's prophecies about the ethical standards prevailing in unorthodox practice are seemingly confirmed. The self-fulfilling character of these ethical prophecies is a powerful force in holding the line against innovation.

Similarly, the medical profession's power over third parties need not be exercised frequently to be effective. Fear of boycotts can serve well enough to prevent many initiatives that would otherwise be taken. Proposed initiatives are frequently submitted for the profession's approval out of respect for its power, and are modified either in advance or afterward to meet the profession's concerns. ${ }^{41}$

\section{B. The Strategy of Preemption and Cooptation: Professionally Sponsored Reforms.}

When many of the more repressive tactics reviewed above were held to be criminal conduct in the $A M A$ case, it suddenly behooved the medical profession to pursue its goals by less obviously offensive measures. Interestingly, the Supreme Court in Oregon State Medical Society observed that what had been a "tooth-and-claw struggle" between the medical society and private "hospital associations" came to an end in 1941, when "there was an abrupt about-face on the part of the organized medical profession in Oregon."42 Failing to note that this change of behavior coincided closely with the first court of appeals decision in the $A M A$ case, ${ }^{43}$ the Court attributed it to a change of heart on the part of the defendant doctor associations and to a new recognition "that the public demanded and was entitled to purchase protection against unexpected costs of disease and accident." 44 Impressed with the profession's farsightedness in adopting its own prepayment plan, the Court failed to attach importance to the Society-sponsored plan's effect of stifling the cost-containment efforts of the hospital associations. It seems that the

40. The Feminist Women's Health Center case, id, also demonstrates the close knit character of the profession in that the staff was able to "persuade" physicians from another community not to do abortions for the clinic by writing letters to the head of the residency program in which they were employed. 415 F. Supp. at 1266.

41. See text accompanying notes 71-72 infra.

42. 343 U.S. at 329 . The "about-face" resulted in the formation of the doctors' own nonprofit corporation to provide prepaid medical, surgical and hospital care on a contract basis. Id. at 330 .

43. United States v. American Medical Ass'n, 110 F.2d 703 (D.C. Cir.), cert. denied, 310 U.S. 644 (1940).

44. 343 U.S. at 329. 
Oregon doctors were more farsighted than the Court knew, because having their own prepayment plan immeasurably strengthened the doctors' ability to resist privately stimulated innovations that might have served consumers better without resorting to egregiously anticompetitive tactics. ${ }^{45}$

Although there is some recognition that professionally sponsored prepayment plans have curbed development of other forms, ${ }^{46}$ it is not widely recognized that this may have occurred not through simple competition so much as through the facilitation of professional restraints of trade. After its long resistance to all forms of prepayment for health care, ${ }^{47}$ the medical profession's decision to offer Blue Shield service plans and to accept indemnity-type insurance had the effect of making its continued resistance to other forms of financing seem plausibly enough related to ethics and patient interests to escape full public scrutiny. The AMA, having successfully assumed the power to regulate prepayment plans, announced certain principles on which it insisted, particularly in plans under private sponsorship. The profession's economic interests played a critical role in the development of the principles adopted. ${ }^{48}$

Lawrence Goldberg and Warren Greenberg have recently reexamined the record in the Oregon State Medical Society case and revealed the degree to which having their own "ethical" insurer in the field permitted doctors to resist the hospital associations effectively. ${ }^{49}$ Although some of the associations remained in business, they entirely abandoned their efforts at cost containment and adopted the passive-insurer role that has now become traditional. ${ }^{50}$ Doctors' refusal to deal directly with the hospital associations was the decisive stroke, but the courts were unwilling, for reasons to be explored later, ${ }^{51}$ to attribute these refusals to deal to a conspiracy. The government did not challenge the legality

45. See notes 50, 56, 57 infra and text accompanying notes 49-57 infra.

46. See, e.g., A. Donabedian, Benefits in Medical Care Programs $270-75$ (1976). Like many other discussions, Donabedian's assumes a certain inevitability in the practical differences between provider-controlled service-benefit plans and traditional insurance. It is submitted that this inevitability flows from the threat of professional retaliation against commercial insurers that seek to change their role.

47. See generally, Comment, The American Medical Association: Power, Purpose and Politics in Organized Medicine, 63 YALE L.J. 937, 976-96 (1954).

48. See id. $985-88$.

49. See Goldberg \& Greenberg 58-62.

50. Although there is evidence that the hospital associations' change of behavior resulted from professional preferences, the timing was such that an alternative explanation might be the reduced interest of consumers in cost containment as a result of the exception made for health benefits in wartime wage controls and the later introduction of favorable tax treatment of health insurance premiums. See text accompanying notes 164-67 infra.

51. See text accompanying notes $186-92$ infra. 
of the profession-dominated prepayment plan itself ${ }^{52}$ despite the competitive advantage that it demonstrably enjoyed and despite its substantial success in facilitating the profession's efforts to discipline the insurance industry. ${ }^{53}$ Goldberg and Greenberg were unable to document $^{54}$ what still seems a likely possibility-namely that the success of the Oregon Physicians Service (OPS) was in large measure attributable to below-cost "disciplinary" pricing. ${ }^{55}$ It seems more than likely that, during the period in which OPS was competing for subscribers and seeking to become the model of insurer conduct, the doctors underwrote the plan's losses by taking less than their full fees allowable under OPS schedules. ${ }^{56}$ The hospital associations, unable to compete against the temporarily low price, submitted to the doctors' rule, thereafter regaining some of the market share they had lost. ${ }^{57}$

A more recent example of concerted professional action to dominate, and thereby limit, innovation in health care financing and delivery is provided by the appearance of so-called "foundations for medical care" (FMCs). ${ }^{58}$ These medical society-sponsored plans follow in the Blue Shield tradition but install a stronger "peer-review" process in an attempt to control costs. Although FMCs are a step in the right direction where they are effective, ${ }^{59}$ they may be seen, like the Blue Shield plans before them, as mild half-measures compared to the independent initiatives they preempt-both independently operated HMOs and insurance plans having their own cost-containment ma-

52. See United States v. Oregon State Medical Soc'y, 343 U.S. 326, 330 (1952) (summarizing the government's basic allegation); Goldberg \& Greenberg 65-66.

53. See Goldberg \& Greenberg 60-61.

54. Id. 77 n.77.

55. See F. Scherer, Industrial Market Structure and Economic Performance 277 (1970).

56. There was evidence that OPS did indeed pay less than 100 cents on the dollar. See Goldberg \& Greenberg 61. It appears that OPS fees were paid at the rate of $85 \%$ of the schedule in 1947. Record at 4786, United States v. Oregon State Medical Soc'y, 343 U.S. 326 (1952). For a possibly comparable situation, see note 298 infra.

57. The doctors' plans had a smaller market share in 1948 than in 1943, suggesting that physicians had become more tolerant of the non-captive plans. See Record at 3519, 5202-03, United States v. Oregon State Medical Soc'y, 343 U.S. 326 (1952).

58. FMCs are medical society-sponsored plans designed to control utilization and costs more effectively than have Blue Shield plans, which they otherwise resemble. See C. STEINwaLD, AN INTRODUCTION to Foundations For Medical CARE (1971); Edgahl, Foundations for Medical Care, 288 NEw ENG. J. MED. 491 (1973).

59. The effectiveness of FMCs in controlling costs has not been established. See INSTITUTE of Medicine, Assessing Quality in Health Care: An Evaluation (1976); Edgahl, Taft, Friedland \& Linde, The Potential of Organization of Fee-for-Service Physicians for Achieving Significant Decreases in Hospitalization, 186 ANNALS OF SURGERY 388 (1977); Gaus, Cooper \& Hirschman, Contrasts in HMO and Fee-for-Service Performance, Soc. SEcurity Bull., May, 1976 , at 3. 
chinery. Indeed, it can be argued that FMCs, although offered by wellintentioned physicians as real reforms, have appeal in the profession primarily because they hold out the hope of forestalling competitive developments such as HMOs and of short-circuiting threatened governmental intrusion. ${ }^{60}$ This suggests the hazard that the FMC, as a token of the profession's good faith and commitment to containing costs without sacrifice of quality, will serve to legitimize the profession's continued antagonism toward more aggressive measures that others might take. ${ }^{61}$

It seems clear that significantly improving the climate for private innovation in cost containment will require closer attention to the benefits and costs of the organized medical profession's involvement in prepayment plans, utilization review and other reforms.

\section{Recent Exertions of Professional Power.}

Although some of the evidence recited above is dated, other evidence suggests that medical organizations are still using their power to shape the economic environment in which physicians operate. Thus HMOs continue to encounter professional opposition in a variety of forms. A Youngstown, Ohio HMO was the subject of a doctor group's formal resolution critical of HMOs generally and calling on its members to deny the HMO an opportunity to work out favorable arrangements with their hospitals. ${ }^{62}$ The Harvard Community Health Plan for a long time found community hospitals closed to it and its physicians, forcing the Plan to use expensive university hospitals. ${ }^{63}$ Exclusion of HMO doctors from a medical service bureau in the State of Washington was halted under a Federal Trade Commission consent order. ${ }^{64}$ While it does not appear that all the less sophisticated forms of professional resistance to HMOs have been dropped, the medical organiza-

60. See text accompanying notes 286-98 infra.

61. A parallel to professionally sponsored reforms appears in current efforts to mount an industry-wide voluntary cost-containment plan. Under prodding from Rep. Rostenkowski, provider groups have organized a cooperative plan for supervising and publicizing hospitals' cost performance, using public opinion and other subtle pressures to bring down the rate of cost increases. See Letter from Richard J. Wertheimer, Esq. and G. Philip Nowak, Esq., to John H. Shenefield, Assistant Attorney General, United States Department of Justice (Antitrust Division) (Feb. 2 1978) (request for antitrust "clearance" of proposed program). In addition to providing a forum for agreements to avoid competition, the proposed program would seem to present the hazard noted in the text. See note 296 infra.

62. Resolution of the Eastern Ohio Council of Hospital Medical Staffs (discovery evidence), Ohio ex rel. Brown v. Mahoning Medical Soc'y, No. C76-168y (N.D. Ohio 1976).

63. Based on conversations with Plan officials and Massachusetts health planners.

64. Medical Serv. Corp., [1977] Trade REg. ReP.(CCH) | 21,195 (FTC Dkt. No. C-2853, Dec. 3, 1976) (consent order). 
tions recently have emphasized political efforts to restrict or delay HMO growth, particularly through use of health planning and certificate-of-need mechanisms, ${ }^{65}$ and organizing competing doctor-sponsored FMCs or similar plans.

Cost-containment efforts by third parties have continued to meet professional resistance. Recent studies by the Council on Wage and Price Stability of private sector cost-control efforts reveal a number of instances of professional association resistance to health care cost-control measures that employers and unions have sought to introduce. ${ }^{66}$ Not long ago, when the Aetna Life and Casualty Company instituted the practice of helping its insureds defend themselves in court against claims by physicians for fees which the insurer had determined were excessive, medical society response was vigorous, and Aetna was forced to conform to professional demands ${ }^{67} \mathrm{~A}$ cost-containment initiative undertaken in Michigan at the instance of the United Auto Workers has prompted an explicit boycott call by the state medical society, which claims that 1900 physicians have refused to deal with Blue Cross-Blue Shield of Michigan as a result. ${ }^{68}$ Other third parties' efforts similar to this one, which involved an attempt to differentiate between cooperative and uncooperative providers, have earned critical resolutions from medical societies elsewhere, including the AMA itself. ${ }^{69}$

The innovation by third-party payers that has seemed most threatening to doctors in recent years is the encouragement, or even requirement, of second opinions prior to elective surgery. Designed to discourage "unnecessary" surgery, these initiatives seem mild compared to what might be tried, ${ }^{70}$ but they have nevertheless occasioned a number of strong reactions from medical groups. For example, recently in the Detroit area three medical societies negotiated the precise nature

65. See Hearings Before Subcomm on Health and Scientific Research of the Senate Comm. on Human Resources, 95th Cong., 1st Sess. (Mar. 3, 1978) (statement of Kaiser Foundation Health Plan, Inc.); id. (testimony by AFL-CIO), reported in HeALTH SEPvices INFORMATION, Feb. 13, 1978, at 3; Kirchner, Where Fee-for-Service is Under the Gun, MED. EcoN., Aug. 8, 1977, at 230; Havighurst, Health Maintenance Organizations and the Health Planners, 1978 UTAH L. REv. 123.

66. See Council on Wage \& Price Stability 109, 116-17.

67. See Goldberg \& Greenberg 62-65.

68. Michigan Prepaid Plan Challenged, Am. Med. News, Jan. 2, 1978, at 1, col. 1. See also MDs to Quit Blue Shield in Michigan, Am. Med. News, Nov. 7, 1977, at 1, col. 1. The flavor of the medical society action can be gathered from the following statement by one doctor: "We've got to march in unison until we have the input that the medical system needs. We must recapture the health care system to assure our patients of quality care." Id. The issue involved in these disputes is discussed in the text accompanying notes 105-33 infra.

69. Indiana MDs Hit Blue Shield Benefit Plans, Am. Med. News, Nov. 14, 1977, at 19, col. 4; Blues' Policies Opposed, Am. Med. News, Dec. 12, 1977, at 7, col. 1 (reporting an AMA resolution).

70. See text accompanying notes $88-94$ infra. 
of these plans with the insurer. ${ }^{71}$ Some of the doctors' demands were apparently nonnegotiable, however, and a threat of a boycott undoubtedly hung over the discussions. It has been customary for health insurers introducing such an innovation in a community to touch base with the local medical society first. ${ }^{72}$ It is important to question why a change in an insurer's benefit package is a matter on which organized medicine should be consulted.

Whether or not the specter of antitrust attack has visibly affected state and local medical societies' efforts to control insurer practices, there is some evidence that the AMA is attempting to moderate its members' anticompetitive impulses. In December 1976, an AMA committee, on the advice of antitrust counsel, withheld from the AMA's membership a report critical of health insurers' second-opinion plans and substituted a milder report. ${ }^{73}$ Although the AMA's lawyers have recognized that antitrust principles require professional associations to take more neutral positions on developments in private health care financing, the lesson has been hard to get across to the doctors themselves. At the AMA's 1977 annual convention, for example, a resolution opposed to insurer-imposed consultation requirements was "overwhelmingly" adopted, to the delegates' cheers, despite the legal department's plea for caution. ${ }^{74}$

Despite the foregoing evidence of ongoing professional efforts to limit private cost-containment initiatives, it may still be difficult, look-

71. MDs Winning "Second Opinion" Fight, Am. Med. News, Apr. 18, 1977, at 1, col.1.

72. Statement by Henry Di Prete, Conference on the Antitrust Laws and the Health Services Industry, sponsored by the American Enterprise Institute for Public Policy Research and Duke Law Journal (Dec. 20, 1977) (transcript on file at Duke Law Journal).

73. "Second Opinion" Statement Weakened, Am. Med. News, Dec. 13, 1976, at 12, col. 1.

74. Resolution 77 requested the AMA to adopt a policy statement regarding mandatory consultation which reaffirmed the right of a patient or physician to seek consultation; opposed the concept of mandatory consultation required by a third party payor and the concept of closed panels of consultants, and supported the concept that consultations required by a third party payor be at no cost to the patient, and that if consultation is required by a third party payor, the patient should be allowed to choose the physician.

Minutes, AMA House of Delegates Meeting, 126th Annual Convention of the AMA, June 1977, Resolution 77 (Policy Statement re Mandatory Consultation, item 38). A news report of the adoption of this resolution is of particular interest:

At the behest of [antitrust] counsel, the delegates reluctantly gagged themselves on several .... issues, but rebellion finally broke out on a matter of mandatory second opinions, which some third parties are opting for as a means of cutting costs. The House was clearly eager to accept a resolution opposing mandatory consultation, but the cautious legal department wanted time to study the implications first.

"This resolution is a clear statement of our views and we ought not to be afraid to adopt it," thundered Georgia's Frederick W. Dowda. "If we ran our offices the way the legal department wants us to run this House, we'd see one patient a week." The delegates cheered and adopted the resolution overwhelmingly.

Permanent President for the AMA?, MED. Wordd NEws, July 25, 1977, at 14, 17. 
ing at current events, to perceive the medical profession as the crucial obstacle in the way of privately initiated major change in health care financing and delivery. The argument, however, is not simply that the medical profession is continually defeating promising initiatives. Instead, it is contended that the profession's power, resulting not only from a surprising degree of consensus within the profession but also from a complex network of frequently subtle but always substantial controls and influences, has conditioned all actors in the health care system and effectively deterred all but the most modest attempts at change. ${ }^{75}$ The foregoing review of the profession's strategic advantages and opportunities for controlling change, along with a record of skirmishes demonstrating the profession's willingness to use its power, should establish, at least, that a potentially serious problem exists. ${ }^{76}$

\section{Assessing the Public Significance of Professional Restraints on ThIRD-Party PaYers}

Despite the foregoing demonstration, there are several reasons why the medical profession's resistance to private cost-containment initiatives might still be thought an insignificant factor in today's crisis in health care costs; thus, it may be asked whether significant changes would in fact occur even if physicians did not collectively oppose them. There is no doubt, for example, that HMOs face many obstacles be-

75. More sweeping innovations supported by groups as powerful as the United Auto Workers have been instituted, but whether they will survive massive resistance by the profession remains to be seen. See note 68 supra and accompanying text.

76. The foregoing discussion of the mechanics of professional domination over the instruments of change in the health care system suggests why certain mechanisms have been more susceptible to professional control than others. It is significant that the most successful innovative plans-for example, such HMOs as the Kaiser Foundation Health Plan and Group Health Cooperative of Puget Sound-are also the most self-contained, possessing their own hospitals and fulltime specialists and being dependent hardly at all on community resources. Although such tight integration is frequently assumed to be essential to achieve administrative efficiency in an HMO, see, e.g., HMO Act of 1973, 42 U.S.C. $\$ 300 \mathrm{e}-(\mathrm{b})(1)(3)$ (Supp. V 1975), as amended by Pub. L. No. 94-460, § 102, 90 Stat. 1945 (1976), this technical explanation for the relative success of more integrated plans may be inacccurate. See Bailey, Economies of Scale in Medical Practice, in EMPIRICAL Studies IN HEALTH ECONOMics 255 (H. Klarman ed. 1972). Instead, HMOs which are dependent (or whose physicians are dependent) on interactions with the local medical establishment may fail to prosper precisely because they are more exposed to obstacles raised by the traditional medical community through its ability to sever essential links with independent providers. Under this hypothesis, traditional insurance and service-benefit plans would be the most vulnerable of all would-be innovators in the health care system. Because their subscribers, enrolled as members of employment groups rather than through individual choice, expect a wide range of choice among available providers, these plans are peculiarly susceptible to boycotts, even highly disorganized ones, and to other retaliatory actions. Despite the difficulty of removing these obstacles, this Article argues that it is possible to employ legal means to improve significantly the prospects for effective cost-containment innovation on the part of these critical actors. 
sides those maintained by the medical communities that they wish to enter. ${ }^{77}$ Moreover, additional private cost containment may be simply unworkable. Perhaps nearly everything worthwhile is already being done, and it is market equilibrium rather than professional opposition that accounts for the slow pace of innovation. It is possible that cost containment has only limited appeal to purchasers of insurance and thus is not saleable in a competitive market.

Examination of these questions is necessary before it can be concluded that reducing professional power over private innovation should be a high-priority objective in the campaign to improve the health care system's performance. The discussion here focuses on the potential ability of third-party payers to impose discipline on the fee-for-service providers whose charges they underwrite. The problems and prospects of HMOs have been extensively treated elsewhere in the literature, ${ }^{78}$ and their omission here reflects not only that fact but also the belief that, as HMOs have received great and deserved attention in recent years, other alternatives for reshaping health care financing and delivery have been neglected. Thus, health insurers, who have been willing to pursue various HMO initiatives, have, for reasons to be explored, ${ }^{79}$ not been especially inventive in other respects, with the result that health care spending by fee-for-service providers remains largely uncontrolled. Although the commercial health insurance industry currently takes the position that innovations in cost containment such as its members might competitively undertake are not in themselves a promising avenue for reform, ${ }^{80}$ this conclusion is vigorously disputed here. Indeed, the argument is that competing third-party payers are the most natural candidates for the cost-containment job, potentially providing a more complete answer to the health care system's cost problems than either HMOs or government regulation.

77. See, e.g., INSTITUTE OF MEDICINE, NAT'L ACAD. SCI., HMOs: TOWARD A FaIR MARKET TEST 19-29, 32-49 (1974).

78. See id; Kissam, supra note 3. Nothing said or left unsaid here is meant to draw support or enthusiasm away from the HMO concept or from attempts to expand HMOs' opportunities. See Iglehart, HMOs-An Idea Whose Time Has Come?, 10 NaT'L J. 311 (1978).

79. See text accompanying notes $139-63$ infra.

80. Their position is that they have done a great deal already, but cannot reasonably be expected to do more. See, e.g., Bailey, Controlling Health Care Costs: The Need for a Cooperative Effort, 9 NAT'L J. 968, 968-69 (1977); Beach, The National Health Care Issue: It's More Than Financing Treatment, 9 NAT'L J. 1014, 1014-15 (1977); Kilpatrick, Prescriptions for Health Care Control: Joint Effort by the Public and Private Sectors, 9 NAT'L J. 1016, 1016-17 (1977). These are all statements by executives of leading health insurers. 


\section{A. Neglected Private Cost-Containment Strategies.}

In order to assess what the public may be losing as a result of the medical profession's influence over private financing schemes, it may be helpful to speculate about what private health insurers might have done, or might now do, to contain health care costs. The following exposition of possibilities is not sheer speculation, however, since closely analogous practices have been adopted in other lines of insurance or have appeared from time to time in medical care only to be suppressed by professional action. The thrust of this discussion is to suggest that a competitive health insurance industry, if it faced undistorted demand for its product ${ }^{81}$ and did not have to defer to organized medicine, would indeed generate effective solutions along the lines to be indicated.

1. Some Possible Insurer Strategies. All the possible steps that might be taken by private health insurers, major purchasers of health insurance, or independent provider groups to contain health insurance premiums and the overall cost of health care cannot be fully elaborated, evaluated or defended here. Nevertheless, the following list of strategies, some of them conceptually challenging to conventional wisdom concerning the nature and purpose of health insurance, suggests the truly vast range of private approaches to medical care cost containment that have not been adequately explored.

(a) High deductibles. This form of cost sharing would put more emphasis on catastrophic risks and less on "shallow" coverage. ${ }^{82}$

(b) Selective coverage. Benefit packages could be designed which expressly exclude specific treatments or procedures from coverage for any of the following reasons: because the treatment's efficacy or its value in benefit/cost terms is in doubt: ${ }^{83}$ because a less costly mode

81. As is noted in the text accompanying notes 164-65 infra, the tax law currently prevents this fundamentally important condition from being fulfilled. Although the issue is not argued at length here, change in the tax treatment of health insurance premiums would probably be the single most important step that could be taken toward improving the private sector's ability to deal with health care costs. See Controlling Health Care Costs 475-78.

82. See Feldstein, The High Cost of Hospitals-And What To Do About $7 t, 48$ PUB. INTEREsT 40, $52-54$ (1977). Primarily because of the tax subsidies that distort demand for health insurance, see text accompanying notes 164-65 infra, current insurance coverage is often excessive in the area of routine, predictable expenses and inadequate in the area of major risks. See also Feldstein, How Tax Laws Fuel Hospital Costs, PRISM, Jan. 1976, at 15, 18-19. See generally Havighurst, Blumstein \& Bovbjerg, supra note 1.

83. For examples of treatments whose coverage might be inappropriate, see A. CoCHRANE, EFFeCTIVENESS AND EFFICIENCY: RANDOM REFLECTIONS ON HEALTH SERVICEs 26-27, 29-32, 4566 (1972). Insurance policies with selective coverage could serve as an effective bulwark against 
of treatment is available and adequate; ${ }^{84}$ or because physician-patient consumption decisions are particularly in need of cost discipline to assure that nonessential care is discouraged. ${ }^{85}$

(c) High copayment requirements. Copayments of up to fifty percent would be appropriate for treatments or procedures that are frequently of doubtful value yet not appropriately excludable from coverage altogether under the principles just stated. ${ }^{86}$

(d) Diagnosis-specific or treatment-specific limits on the duration of hospitalization coverage. For example, a limit on the number of covered days of postoperative hospital care, varying with the procedure or diagnosis and subject to exceptions for complications, would stimulate private benefit/cost assessments of continued stays and many earlier discharges. ${ }^{87}$

(e) Second-opinion requirements prior to elective surgery. These could range in stringency from simply covering the cost of a voluntary second opinion-which the medical profession accepts-to conditioning coverage on obtaining a confirming opinion. ${ }^{88}$ In the latter case,

the introduction of new technologies whose benefits are not known to exceed their costs. Although such technologies are widely perceived as inflationary and as requiring governmental controls, private-sector action could do much to solve the problem.

84. In such a case, it might be preferable to provide a cash indemnity equal to the cost of the less expensive treatment, allowing the patient to supplement those funds if he believed the more expensive treatment was desirable. A less flexible approach is taken in the federal "maximum allowable cost" rules for reimbursing the cost of prescription drugs under the Medicare and Medicaid programs which force the patient to accept a generic rather than a brand-name drug unless he can obtain a special physician's certification. 45 C.F.R. $\$ 19$ (1976).

85. For the argument that the "moral hazard," as reflected in the elasticity of demand for a particular medical service, is a relevant factor in the consumer's decision to insure or self-insure against the need for that service, see Havighurst, The Role of Competition in Containing Health Care Costs in FTC 359.

86. Such coverage might be appropriate for a procedure such as costly coronary by-pass surgery, which apparently can be effective in relieving symptoms but not in prolonging life. See, e.g., Braunwald, Coronary-Artery Surgery at the Crossroads, 297 NEw ENG. J. MED. 661, 662 (1977). The conventional practice is to employ copayments, if at all, across the board and at levels unlikely to have much impact. Economists have largely confined their research to the effect of costsharing on consumption of medical care in general and have not looked at demand for discrete services. See, e.g., Newhouse, Phelps \& Schwartz, Policy Options and the Impact of National Health Insurance, 290 NEw ENG. J. MED. 1345 (1974); Newhouse \& Phelps, New Estimates of Price and Income Elasticities of Medical Care Services, in THE ROLE OF HEALTH INSURANCE IN THE Health Services Sector 261 (R. Rosett ed. 1976).

87. A physician friend recently described to me an uninsured patient, capable of paying her own bills, whom he was able to discharge two days after surgery even though the normal stay would have been five days. This suggests that, instead of front-end deductibles, limitations at the other end, where marginal benefits of additional care rapidly decline, would be more rational. For a powerful demonstration of the principle's importance, see note 104 infra.

88. See Council on Wage \& Price Stability 105-18. For the medical view, implying an 
note that, as with other coverage limitations, the patient and the physician may still proceed with surgery, though not at the insurer's expense.

(f) Prior insurer authorization requirements. This could be used as a condition of coverage of nonemergency hospitalization or surgery. ${ }^{89}$

(g) PSRO-type utilization review. ${ }^{90}$ Such review would limit coverage to essential care as determined on a case-by-case basis and would be needed in administering exceptions to express exclusions. Unlike the PSRO program, however, it should be clear that it is the plan's coverage, not good medical practice, that is being defined. ${ }^{91}$ The PSRO program is disappointing expectations primarily because it embodies the view that anything not bad medicine should be paid for. ${ }^{92}$ In private insurance schemes exclusions from coverage could rationally be based on other grounds. ${ }^{93}$

(h) Predetermination of benefits. This would enable the patient and, at least equally important, the physician to know in advance of nonemergency treatment what costs the insurer will or will not bear. With complex coverage rules of the varieties suggested here, predetermination of benefits, which is widely employed in dental insurance, ${ }^{94}$ would seem essential.

obligation on the part of third-party payers to pay for anything that is not fraudulent, see Paulshock, "Unnecessary" Surgery: Who'll Have the Final Say?, MED. EcoN., Mar. 7, 1977, at 75. See also text accompanying notes 73-74 supra.

89. For an historical example, see Goldberg \& Greenberg 51-53. See also Amago v. Cuban Clinic Ass'n of Hialeah, 345 So. 2d 1091 (Fla. App. 1977) (refusal to pay subscriber's medical expenses because subscriber failed to provide letter of admission to participating hospital; summary judgment for defendant insurance company reversed).

90. On PSROs, see Grad, Professional Self Discipline, 1978 DUKE L. J. 443; Havighurst \& Blumstein.

91. This point is both legally and ethically important. See Controlling Health Care Costs 496 n.62.

92. By treating the PSRO program as regulatory, the profession has assured that it will have little impact, eliminating fraud and sheer waste but not forcing attention to trade-offs at the margin. See generally Havighurst \& Blumstein. Recent studies sponsored by the Department of Health, Education and Welfare indicate that the PSRO program has had little effect. See OFFICE of Planning, Evaluation and Legislation, Health Services Administration, PSRO: AN Evaluation of Professional Standards Review Organizations (Executive Summary 1977).

93. See note 85 supra.

94. See K. Nash, S. Garfinkel \& F. BRYan, Identify and Describe Quality Assurance Methodologies as Employed by Selected Third-Party Carriers of Prepaid DenTAL Plans (Center for Health Studies, Research Triangle Institute; prepared for Div. of Dentistry, Dep't of Health, Education and Welfare) (1975); CouNCLL ON WAGE \& PRICE STABILITY 115-18. 
(i) Insurer loans. ${ }^{95}$ These loans would permit insureds to finance the cost of excluded treatments or large copayments. Exclusion from coverage under the foregoing strategies implies neither that the treatment is never medically appropriate nor that consumers would be wrong to purchase the treatment. On the contrary, some care that is customary and often advisable but not clearly essential in all cases should be paid for out of pocket, at least in part, in order to retain cost as a discipline for patients and physicians.

(j) Contractual alteration of patients' malpractice rights. This is a means of reducing the perceived necessity for practicing costly "defensive" medicine. ${ }^{96}$ Many approaches are possible, ranging from a simple arbitration requirement ${ }^{97}$ to the substitution of a limited "no-fault" compensation system for the insureds' right to sue in tort for specified adverse outcomes. ${ }^{98}$

(k) Cash benefits. Predetermined cash benefits which are based on the diagnosis or the treatment selected and which are payable without regard to actual cost give the patient both the funds to obtain needed care and the incentive to spend them wisely. ${ }^{99}$ Although such a departure from reimbursement for incurred costs may be unattractive for some purposes, ${ }^{100}$ cash benefits could be used selectively. For exam-

95. See Seidman, Medical Loans and Major-risk National Health Insurance, 12 HeALTH SERVICES RESEARCH 123 (1977).

96. Defensive medicine has been defined as either

(a) the use of diagnostic and other resources primarily for the purpose of protecting the physician against a successful malpractice claim rather than the patient against an adverse medical result or (b) the refusal to provide needed care or to adopt desirable new methods out of a concern that exposure to liability would be increased . . .

Havighurst, "Medical Adversity Insurance"-Has Its Time Come?, 1975 Duke L.J., 1233, 1235. See generally Project, The Medical Malpractice Threat: A Study of Defensive Medicine, 1971 DuKE L.J. 939.

97. See Madden v. Kaiser Foundation Hosps., 17 Cal. 3d 699, 552 P.2d 1178, 131 Cal. Rptr. 882 (1977) (upholding an arbitration clause negotiated by the state for its employees); Doyle v. Giuliucci, 62 Cal. 2d 606, 401 P.2d 1, 43 Cal. Rptr. 697 (1965).

98. See O'Connell, No-Fault Liability by Contract for Doctors, Manufacturers, Retailers and Others, 632 INs. L.J. 531, 532-37 (1975). O'Connell has not considered alteration of the liability relation through the health insurance contract, as opposed to direct doctor-patient agreements, but the proposal has the substantial advantage of allowing the cost-saving benefits of the changed liability rule to accrue to the insureds themselves. In addition, this proposal would considerably reduce the problem of unconscionability. See id. 540-42; Havighurst, supra note 96, at 1276-77. See also Epstein, Medical Malpractice: The Case for Contract, 1976 AM. B. Foundation RESEARCH J. 87.

99. See note 84 supra.

100. Frequently the diagnosis will be unclear, or complications will exist so that the prescribed cash benefit is insufficient to avoid hardship. 
ple, ancillary services during certain hospital stays could be covered by a fixed-sum payment so as to discourage unnecessary tests and $\mathrm{x}$-rays.

(l) Fee schedules for professional services. ${ }^{101}$ Again, a range of approaches is available, from simply limiting the indemnity payable to the patient, leaving him to negotiate the actual fee, to establishment of a closed panel of physicians who have agreed to accept the schedule. In lieu of uniform fees, an insurer could negotiate fees with individual physicians.

\section{(m) Prior negotiation of hospital charges between the plan and the hospitals. ${ }^{102}$}

(n) Adjustment of premiums according to the insured's choice of hospital at the time of enrollment. ${ }^{103}$

(o) Payment of hospitals on the basis of diagnosis. This would provide an inducement for early discharge where health services research indicates an opportunity to shorten customary lengths of stay. ${ }^{104}$

Most of the foregoing strategies would present formidable administrative problems and would not work unless the cooperation of a sufficient number of individual providers could be obtained. Indeed, the success of any cost-containment effort probably depends more on the plan's ability to select cooperative and cost-conscious physicians

101. See Kallstrom. See also text accompanying notes 105-33 infra.

102. See, e.g., Webster County Memorial Hosp., Inc. v. United Mine Workers Welfare \& Retirement Fund, 536 F.2d 419 (D.C. Cir. 1976) (upholding a union's bargaining with a hospital for a fixed per diem charge). HMOs have sometimes been able to negotiate a favorable rate for their subscribers.

103. See Newhouse \& Taylor, How Shall We Pay for Hospital Care?, 23 Pub. InTERest 78 (1971).

104. A recent study indicates that many heart attack victims can be safely discharged after a one-week hospital stay with potential savings estimated at $\$ 360$ million per year. McNeer, Wagner, Ginsburg, Wallace, McCants, Conley \& Rosati, Hospital Discharge One Week After Acute Myocardial Infarction, 298 NEw ENG. J. MED. 229 (1978). This finding has prompted a proposal to change incentives by giving the hospital "a certain fixed payment for each patient with a certain diagnosis irrespective of the duration of stay." Ross, Early Discharge After Heart Attacks and the Efficient Use of Hospitals, 298 New ENG. J. MED. 275, 276 (1978). Dr. Ross does not examine how this revolutionary approach could be implemented, though he implies that government regulation would be appropriate. But a private arrangement negotiated with a hospital by an insurer on behalf of its insureds, who reap the benefit in lower premiums, would be one possibility. Another simple way of meeting the cost issue would be simply to limit insurance coverage to one week in accordance with the principle stated in the text accompanying note 87 supra. Dr. Ross' proposal departs from the traditional approach of appealing simply to providers' professionalism to induce a desirable change in medical practice, but, in looking instead to provider incentives, he neglects the more readily implementable alternative of relying on consumer incentives to stimulate privately negotiated change. 
than on the precise coverage limits or administrative mechanisms employed. Insurers have an obligation to explore aggressively the opportunities for offering their insureds a range of lower-cost options featuring selective coverage, administrative controls and restricted choice of physician, in addition to traditional comprehensive coverage with free choice of physician.

2. Enlisting Physician Cooperation: Provider Panels. The real key to effective private cost-containment efforts-whether using the foregoing strategies or some other approach-is the formal enlistment of individual providers as willing participants in the plan. By the same token, care rendered by noncooperating providers must be either excluded from insurance coverage altogether ${ }^{105}$ or paid for on a different basis so that patients bear personally at least the excess cost entailed by their decision to patronize such providers. The enlistment of "participating" providers is necessary not only to effectuate the use of negotiated fee schedules and to exclude uncooperative providers but also to obtain compliance with such administrative controls as might be necessary to implement complex coverage limitations introduced to restore provider and patient cost consciousness at appropriate decision points.

The idea of panels of voluntarily participating providers is not unfamiliar to the insurance industry nor is it an alien concept in the health policy debate. Such panels have been used successfully in prepayment plans for dental, ${ }^{106}$ pharmacy, ${ }^{107}$ optometric, ${ }^{108}$ auto repair, ${ }^{109}$ burial, ${ }^{110}$ and legal ${ }^{111}$ services. With respect to medical care, Blue Cross and Blue Shield plans have routinely employed participation agreements for physicians and hospitals. Although such agreements usually have been neither particularly burdensome to participating providers

105. Note the parallel to HMOs, which pay for care provided by non-HMO doctors only where it is provided on an emergency basis outside of the area which the HMO serves. Just as the consumer might buy into such a plan, he might choose an insurance plan that limits the providers to whom he has access at the insurer's expense.

106. See Manasen v. California Dental Serv., 424 F. Supp. 657 (N.D. Cal. 1976). See also K. NASH, S. GARFINKEL \& F. BRYAN, supra note 94.

107. See Royal Drug Co. v. Group Life and Health Ins. Co., 556 F.2d 1375 (5th Cir. 1977), cert. granted, 98 S. Ct. 1448 (1978); CouncIL on Wage \& Price STABILITY 119-24. For a legal discussion of prepaid drug plans, see Kallstrom 669-74.

108. See Council on Wage \& Price Stability 155-56.

109. See Proctor v. State Farm Mut. Auto Ins. Co., 561 F.2d 262 (D.C. Cir.), petition for cert. filed, 46 U.S.L.W. 3375 (Oct. 19, 1977) (No. 77-580); Hill v. National Auto Glass, 293 F. Supp. 295 (N.D. Cal. 1968).

110. See Battle v. Liberty Nat'l Life Ins. Co., 493 F.2d 39 (5th Cir. 1974), cert. denied, 419 U.S. 1110 (1975).

111. See N. Pfennigstorf \& S. Kmmall, Legal Service Plans: Approaches to ReouLATION (forthcoming); Kallstrom 674-78; Pfenningstorf \& Kimball, Regulation of Legal Service Plans, 1977 AM. B. Foundation ResearCh J. 359. 
nor significantly disadvantageous to nonparticipants, ${ }^{12}$ current controversies in Michigan and Massachusetts reveal their potential for achieving effective control. ${ }^{113}$ Panels of fee-for-service providers, called "individual practice associations," are contemplated in the federal Health Maintenance Organization Act of 1973. ${ }^{114}$ Another indication of the viability of the panel concept is Dr. Paul Ellwood's recent proposal for creating "health care alliances"-clusters of doctors and hospitals separately rated for insurance purposes and competing against similar alliances and HMOs. ${ }^{15}$ A new approach to national health insurance, embodied in a proposal for a "Consumer-Choice Health Plan," leaves room for competing panels of fee-for-service practitioners as one option for consumers. ${ }^{116} \mathrm{~A}$ California insurer offers insureds the option of signing up with one of its participating primary-care physicians, who then supervises all referrals and hospitalizations to assure the appropriateness of care. ${ }^{117}$

Historically, too, the panel-medicine approach has been a continual contender for a role in health care delivery, not only in the United States but elsewhere. ${ }^{118}$ But patterns violating the principle of "free choice of physician" have survived professional counterattacks in only a few places. The most notable success, of course, was the survival of prepaid group practice HMOs in the United States as a direct result of the invocation of the antitrust laws in the $A M A$ case. Unfortunately, a similar attempt to use the antitrust laws to vindicate health insurance plans with cost-containment and panel-medicine features failed in the

112. See Anderson v. Medical Serv., 1976-1 Trade Cases If 60,884 (E.D. Va. 1976), affd mem, 551 F.2d 304 (4th Cir. 1977).

113. See New Blue Shield Policies Stir Protests from Michigan M.D.s, Am. Med. News, Sept. 19, 1977, at 1, col 2; Medical Society To Sue Blue Shield, Am. Med. News, Oct. 31, 1977, at 1, col. 1. On further developments in Michigan, see note 68 supra and accompanying text.

114. 42 U.S.C. $\S \S 300$ e to 300 e-15 (Supp. V 1975), as amended by Pub. L. No. $94-460$, $\S \S 101-$ 116, 90 Stat. 1945-55 (1976). Although HMOs authorized by the Act might serve as vehicles for some cost-containment strategies, the Act contains restrictions that would preclude the use of many of the approaches suggested in the the text. In particular, the Act requires that benefits be comprehensive, $i d . \S 300 \mathrm{e}(\mathrm{b})(\mathrm{I})$, making the strategy of selective coverage unavailable. Nevertheless, standards of practice in an HMO might be, and usually are, less resource-consuming than in the fee-for-service sector. Kissam, supra note 3, at 488 n.3. The consumer's choice of an HMO may therefore be interpreted as a choice of more selective coverage.

115. See Reynolds, A New Scheme to Force You to Compete for Patients, MEd. Econ., Mar. 21, 1977, at 23.

116. See Enthoven. See text accompanying notes 308-10 infra. For a brief discussion of Enthoven's plan, which fundamentally (and unnecessarily) departs from the approach endorsed here, see note 309 infra.

117. See Enthoven, Shattuck Lecture-Cutting Cost Without Cutting the Quality of Care, 298 New ENG. J. MEd. 1229, 1232-33 (1978).

118. See B. Abel-Smith, Value for Money in Health Services 8-11 (1976). 
Oregon State Medical Society case. ${ }^{119}$ Current professional efforts to combat aggressive use of the panel-medicine concept to control insurance costs include an explicit boycott in Michigan and litigation challenging the legitimacy of compulsory-participation plans. ${ }^{20}$

Provider participation agreements can present some difficult legal issues, since not all of organized medicine's antipathy to such plans is unjustified. To the extent that an insurance plan wields monopsony power-market power as the dominant purchaser in the market-there may be a socially objectionable opportunity for it to exploit providers, driving their fees below a fair, competitive level. ${ }^{121}$ Although the anti-

119. See text accompanying notes $42-45$ supra.

120. See note 68 supra and text accompanying notes $68-69,112-13$ supra.

121. A monopsonist can exploit producers only where the latter have unrecoverable fixed costs, making it rational for them to stay in business even though their total costs are not covered by the price they obtain. By setting a price at least equal to out-of-pocket costs plus a fair return on recoverable capital, a monopsonist can keep his suppliers in business while denying them a return on their original investment. But, because little new capital will be invested in an industry facing a monopsonistic purchaser, the monopsonist will ultimately have to relax his grip in order to maintain a source of supply. Health professionals, particularly physicians, are potentially subject to monopsonistic exploitation because their considerable investments in education, including wages forgone, cannot be recovered and because their alternative employments are not likely to be as lucrative or personally satisfying. This means that most health professionals would stay in their professions even if their incomes were drastically reduced, and it might therefore be tempting to would-be monopsonists-including large purchasing groups, such as labor unions and perhaps the federal government as well--to take advantage of their vulnerable situation.

Of course, this scenario is upset by the presence of substantial monopoly power on the professionals' side of the market. See note 174 infra and text accompanying notes 174-75 infra. Monopoly provides a possible warrant for introducing monopsony, thereby substituting prices arrived at by collective bargaining between parties of equal power for the present monopolistic price structure. Viewing the matter in this way, some consumer advocates have favored monopsonistic policies toward health care providers, see, e.g., S. LAW, BLUE CROSS, WhAT WENT WRONG? (1974), and government regulation is apt to have monopsonistic features, see note 131 infra. For a thoughtful discussion, see Starr, Controlling Medical Costs Through Countervailing Power, WORKING PAPERs FOR A New SocIETY 10 (Summer 1977), which nevertheless underestimates the variety of responses available to competing insurers. See also Somers \& Somers, $A$ Proposed Framework for Health and Health Care Policies, 14 INQUIRY 115, 156-61 (1977); A. Somers, Negotiated Rates: One Road to Strengthening the Private Sector and Cost Containment in Health Care (Sept. 20, 1977) (unpublished paper prepared for a conference on The Future of the Private Sector in Medical Care and Education, Duke Medical Center).

This Article argues that private monopsony, like regulation and public takeover of health care financing, is an inappropriate response to the monopoly problem if it is also possible to eliminate the monopoly and restore workable competition. Nevertheless, the case against using private monopsony to correct the current imbalance of power in favor of the medical profession should not be overstated. Local monopsonies would not be able to exploit doctors significantly as long as doctors can relocate their practices and can individually refuse to deal with plans that underpay, thereby inviting market entry by other plans. The argument that physicians might be unfairly exploited, while valid, is not overpowering because most physicians have probably already recovered their educational investments through monopoly profits and because the profession's past abuses are not entirely irrelevant in forming future policy. Finally, although it would certainly be undesirable to squeeze physicians to the point of drying up the pool of applicants to 
trust laws should be as concerned with providers victimized by a monopsonistic combination of buyers ${ }^{122}$ as with consumers exploited by a provider cartel, recent case law interpreting the McCarran-Ferguson Act's exemption of the "business of insurance" from the antitrust laws ${ }^{123}$ threatens to expose providers of insured services to exploitation by dominant insurance plans. In one case, for example, an alleged horizontal combination of automobile insurers was seemingly given the benefit of the McCarran exemption, despite allegations that they exploited auto repair shops. ${ }^{124}$ The law in this area is unsettled, however,

medical school, the length of the queue of qualified applicants today suggests that medical fees could be reduced substantially without unduly affecting the supply of doctors.

In general, the strongest objection to monopsony is probably not that it is unfair or exploitative but that it legitimizes the perpetuation of the very monopoly it confronts and embraces the collective-bargaining model. Such a system yields unpredictable results and leads to such things as doctor strikes and the standardization and depersonalization of care. Moreover, it would do little about the troublesome ideological dimension of the physician monopoly. See note 214 infra. Although some think that confrontations with physicians, using monopsonistic vehicles, can break down physicians' ideological dominance, this Article looks to a more competitive, pluralistic system for solutions to that problem.

122. Monopsony has received little attention from antitrust courts and has more frequently been dealt with as a public policy problem through legislation setting aside antitrust prohibitions against producer combinations so that producers can wield monopoly power against a monopsonistic purchaser. See, e.g., Capper-Volstead Act, 7 U.S.C. \& 291 (1976) (agricultural cooperatives); Fisheries Cooperative Marketing Act, 15 U.S.C. \& 521 (1976); and the labor exemption from the antitrust laws in sections 6 and 20 of the Clayton Act, 15 U.S.C. $\S 17$ (1976), 29 U.S.C. $\S 52$ (1970). Although the medical profession's claim to the benefit of the labor exemption was rejected in the $A M A$ case, the court of appeals, in discussing the issue, stated:

[I] $f$ the laity were so dominantly organized into consumer cooperatives that it might properly be said of the physician, as of the individual unorganized worker, that he is

"commonly helpless .... to obtain acceptable terms and conditions of employment,

..." or protection "from the interference, restraint, or coercion of employers of labor,

..." then possibly the two Acts would be applicable.

130 F.2d at 242-43 (footnote omitted); cf. United States v. National Ass'n of Real Estate Bds., 339 U.S. 485 (1950) (real estate brokers are not entitled to the labor exemption). Obviously, no one is currently prepared to suggest that physicians are so helpless. But of. note 304 infra and text accompanying notes 304-05 infra. On the contrary, monopsony is offered as a response to entrenched provider monopolies. See note 121 supra.

123. 15 U.S.C. $\$ \$ 1011-1015$ (1976). See generally Weller, The McCarran-Ferguson Act's Antitrust Exemption for Insurance: Language, History and Policy, 1978 DUKE L.J. 587; Kallstrom 684 89.

124. Proctor v. State Farm Mut. Auto. Ins. Co., 561 F.2d 262 (D.C. Cir.), petition for cert. filed, 46 U.S.L.W. 3375 (Oct 19, 1977) (No. 77-580). See note 130 infra. In another case, a prepaid dental services plan was held exempt without significant attention to either its possible possession of monopsony power or the possibility that its discriminatory treatment of nonparticipating dentists vent too far. Manasen v. California Dental Serv., 424 F. Supp. 657 (N.D. Cal. 1976). However, neither possibility seems substantial from the published opinion. Indeed, the plan appeared to have professional sponsorship and may have presented hazards of an order very different from those raised by the plaintiff. See text accompanying notes $279-85$ infra. A similar case involving a Blue Shield plan with a 37\% market share was resolved against the protesting physician in the same way. Anderson v. Medical Serv., 1976-1 Trade Cases I 60,884 (E.D. Va. 1976), affd mem., 551 F.2d 304 (4th Cir. 1977). However, as compared with the plans in Proctor and Manasen, the Anderson plan was less discriminatory toward nonparticipating providers. 
and the most recent case refused to extend the McCarran exemption to a prepaid drug plan which allegedly treated small pharmacists unfairly. ${ }^{125}$ This case, Royal Drug Co. v. Group Life and Health Insurance Co., is currently pending in the Supreme Court, and it is to be hoped that it will be resolved in such a way as to guarantee insurers wide latitude in using provider participation agreements for cost-containment purposes while also giving providers protection in true monopsony situations. ${ }^{126}$

Practical solutions to the monopsony problem seem available and could be readily implemented without jeopardizing the legitimate costcontainment measures that insurers might take to limit the cost-escalating tendencies that insurance itself introduces and to counter the monopoly power of providers. A guarantee that monopsony power was not being exercised could be achieved by insisting in cases presenting the hazard that care rendered by nonparticipating providers not be altogether excluded from coverage. Instead, such care might be paid for

125. Royal Drug Co. v. Group Life \& Health Ins. Co., 556 F.2d 1375 (5th Cir. 1977), cert. granted, 98 S. Ct. 1448 (1978). The small pharmacists claimed that they could not afford to accept the plan's low dispensing fee but insisted they were competitive on the basis of service. Insofar as the allegations of the complaint seemed to suggest monoponistic abuse, they were untenable in view of the willing participation of three large drug chains. The allegations of a horizontal conspiracy by these chains, however, should take the case out from under the McCarran exemption. See note 126 infra.

126. The case might be resolved by holding that the McCarran Act does not shelter provider participation agreements at all. In that event, Sherman Act principles would apply, and, even though they would not prohibit insurer-provider agreements tailored to business needs, see note 128 infra and accompanying text, some uncertainty concerning the precise rules governing such agreements would prevail among insurers at least until the decision on remand. Confusion would also result from overturning the ground of the reassuring decisions cited in notes 124 supra and 130 infra, leaving insurers to speculate on how these cases would have come out under a Sherman Act analysis. See note 130 infra. Despite these concerns, a ruling against the McCarran exemption would have some merit in permitting antitrust scrutiny of monopsonistic insurance plans, of possibly exclusionary terms in insurer-provider agreements and of any implicit or explicit horizontal agreements among providers. State insurance regulators are not equipped to deal with competitive effects in businesses other than "the business of insurance," see note 131 infra, and there is no basis in legislative history for sheltering such effects from antitrust attention. See Weller, supra note 123 , at $598-602$.

Despite these arguments for not recognizing any McCarran exemption, provider participation agreements designed to combat the impairment of consumer cost-consciousness caused by insurance itself can be viewed, contrary to the Royal Drug court's perception, $556 \mathrm{~F} .2 \mathrm{~d}$ at 1383 , 1386, as "peculiar to the insurance industry," suggesting that such agreements should qualify as part of the "business of insurance," as discussed in the text accompanying notes 128-33 infra. This reading would square with the decided cases, would allow the Supreme Court to settle most of the uncertainties in its Royal Drug opinion instead of remanding for a full antitrust evaluation, and would leave the antitrust courts with jurisdiction to prevent all of the possible abuses which insurerprovider agreements might be used to perpetrate. Such a reading would apparently leave the Royal Drug plaintiffs a chance to prevail if they could prove their somewhat far-fetched claim that there was a conspiracy of participating pharmacies to drive them out of business and to achieve a shared monopoly. 
on a different basis, perhaps with a copayment roughly reflecting the higher costs (in fees, utilization and administration) necessitated by such providers' nonparticipation. ${ }^{127}$ Such an agreement would allow an insurance plan to offer "free choice of physician," which many insureds enrolled as members of employment groups might desire or even require in order to avoid having to change doctors. But choice of a nonparticipating provider would carry a price tag, supplying a desirable incentive to opt for the panel with its lower costs.

Legally, it would seem possible to employ antitrust principles to ensure the fair treatment of nonparticipating providers wherever the insured group represents an undue concentration of buying power. This result could be reached simply by treating as within the "business of insurance" for McCarran Act purposes, and thus exempt from antitrust attack, only those practices that are reasonably necessary to protect an insurer and its insureds against overcharges or overutilization. So construed, the McCarran exemption would extend no further in these cases than the Sherman Act's usual tolerance for "ancillary" restraints imposed as an incident to achieving a legitimate business purpose. ${ }^{128}$ Language in the leading Supreme Court precedent on the

127. The cases reveal a variety of ways of treating nonparticipating providers. One variable is the plan's willingness to pay such providers directly, relieving the insured of the necessity for filing a claim. Compare Anderson v. Medical Serv., 1976-1 Trade Cases I 60,884, at 68,856 (E.D. Va. 1976), affd mem., 551 F.2d 304 (4th Cir. 1977) (payment to subscriber) with Traveler's Ins. Co. v. Blue Cross, 481 F.2d 80, 84 n.12 (3d Cir.), cert. denied, 414 U.S. 1093 (1973) (payment to providers). Another variable is the amount of the discount, if any, from the fee regularly payable. Compare Anderson (no discount) with Royal Drug Co. v. Group Life \& Health Ins. Co., 556 F.2d 1375 (5th Cir. 1977), cert. granted, 98 S.Ct. 1448 (1978) (subscriber patronizing non-participating druggist reimbursed $75 \%$ of amount paid participant). There is as yet no case where a payment differential was based explicitly on risk differences resulting from the absence of utilization controls. A plan attempting to control costs in good faith should not have to justify its differentials by minute cost calculations. Given the clear business purpose, the burden of proof should be on the providers challenging the plan's reasonableness.

128. See United States v. Addyston Pipe \& Steel Co., 85 F. 271 (6th Cir. 1898), affd, 175 U.S. 211 (1899); United States v. Columbia Pictures Corp., 189 F. Supp. 153 (S.D.N.Y. 1960); United States v. Morgan, 118 F. Supp. 621 (S.D.N.Y. 1953). A practice that falls outside the McCarran exemption is not, of course, necessarily a substantive antitrust offense. Requiring insureds to patronize only "participating" providers is a restraint of trade, however, and deciding whether it would constitute an antitrust violation requires analysis under the rule of reason with help from any analogies that can be drawn from established antitrust doctrine. It should be clear that the use of a fee schedule by an insurer would not, without more, amount to unlawful price fixing. See Anderson v. Medical Serv., 1976-1 Trade Cases \ 60,884 (E.D. Va. 1976), aff d mem., 551 F.2d 304 (4th Cir. 1977); Kallstrom 679; cf. 91 HARV. L. REv. 488 (1977) (critique of the application of the price-fixing label to a joint selling agent performing a commercial function analogous to the insurer's buying function here). Neither is there a boycott since any refusal to deal is wholly incidental to the consumers' individual decisions to join the plan and patronize its participating providers instead of their competitors.

In the absence of a horizontal agreement among insurers, insureds or providers, provider participation agreements may be analyzed as a kind of vertical restraint. Since complaints origi- 
McCarran exemption suggests that just such a functional analysis is intended, ${ }^{129}$ and the courts have in fact examined insurer-imposed restraints in just this way, tolerating restraints that are tailored to a business need. ${ }^{130}$

nate with providers rather than consumers, an analogy to cases condemning maximum-price fixing as a restriction on the "freedom of traders" is suggested. Albrecht v. Herald Co., 390 U.S. 145 (1968); Kiefer-Stewart Co. v. Joseph E. Seagram \& Sons, 340 U.S. 211 (1951). Those cases invalidated sellers' attempts to curb monopoly power being wielded by their distributors, and might be read to deny an insurer of the defense that its "price fixing" was to offset providers' market power or some other market defect. In the absence of demonstrable monopsony, however, this defense should be permitted, and the Albrecht and Kiefer-Stewart cases distinguished on the ground that other remedies (termination of exclusive territories and litigation against the distributor cartel) were realistically available in those cases but not here.

Though having some of the characteristics of bilateral exclusive dealing and tying agreements, the contemplated arrangement is tripartite, suggesting a possible analogy to the "TBA" (tires, batteries and accessories) cases, in each of which an oil company favored a particular TBA manufacturer over others as supplier to its independent service stations. FTC v. Texaco, Inc., 393 U.S. 223 (1968); Atlantic Refining Co. v. FTC, 381 U.S. 357 (1965); Shell Oil Co. v. FTC, 360 F.2d 470 (5th Cir. 1966), cert. denied, 385 U.S. 1002 (1967). However, those arrangements served no apparent economic purpose, foreclosed competitors willing to compete on price, reflected the oil companies' coercive power over ostensibly independent retailers, and were condemned only under $\S 5$ of the Federal Trade Commission Act, not the Sherman Act.

The arrangements examined here are more defensible than those in the maximum-price fixing and TBA cases. Nevertheless, standard antitrust analysis applicable to ancillary price fixing, the Columbia Pictures and Morgan cases, and CBS, Inc. v. American Soc'y of Composers, Authors \& Publishers, 562 F.2d 130 (2d Cir. 1977), discussed in 91 HARv. L. REv. 488 (1977), and joint ventures suggests that a legitimate business purpose, such as appears here, is not a sufficient defense when there is also present both an actual effect on prices (or enough market power to have such an effect) and an available less restrictive alternative. See generally P. AREEDA, ANTITRUST ANALYSIS 348, 380, 409-10 (1974). The argument here is thus that the same facts that should render the "business of insurance" exemption unavailable-market power and a less restrictive alternative-also establish the substantive Sherman Act violation. See Kallstrom 688 (adopting the analysis suggested here with somewhat less attention to the monopsony issue); $c f$. St. Paul Fire \& Marine Ins. Co. v. Barry, 98 S.Ct. 2923 (1978) (the "boycott" exception to the McCarran exemption construed with reference to the term's Sherman Act meaning, making the exemption's boundary for those purposes congruent with the boundary of the substantive violation). Admittedly, some difficulty would be presented by the need to measure monopsony power (a structural issue calling attention to market share and entry conditions) and to distinguish monopsonistic effects from the price-lowering effects of introducing competition where a provider monopoly previously prevailed.

129. SEC v. National Sec., Inc., 393 U.S. 453, 460 (1969):

The relationship between insurer and insured, the type of policy which could be issued, its reliability, interpretation, and enforcement-these were the core of the "business of insurance." Undoubtedly, other activities of insurance companies relate so closely to their status as reliable insurers that they too must be placed in the same class.

Whatever contributes to running a sound and competitive insurance plan and to offsetting the distorting effects of insurance in the market for insured services could easily fit within this definition of the "business of insurance."

130. Under the recommended analysis, the court in Proctor v. State Farm Mut. Auto. Ins. Co., 561 F.2d 262 (D.C. Cir.), petition for cert. filed, 46 U.S.L.W. 3375 (Oct. 19, 1977) (No. 77-580); (see text accompanying note 124 supra), should have examined the alleged horizontal arrangements among insurers to see if any ancillarity defense-data exchange or joint claims adjustment, for example, (see note 158 infra)-could be made out. Although the court appeared to tolerate the danger that body shops would be exploited, the court of appeals did apply the recommended 
Under such a rule-of-reason approach, a discriminatory restriction adopted by an insurer when an equally effective but less restrictive alternative was available would be subject to antitrust attack if the insurer was a dominant purchaser and if state law did not specifically authorize the monopsonistic restraint. ${ }^{131}$ Room would thus be left both

analysis in determining that the specific treatment of nonparticipating shops was reasonable and not a "boycott, coercion, or intimidation" subject to the Sherman Act. 561 F.2d at 274-75. Also, it found no evidence to support the charge of conspiracy. Id. at 276. For these reasons, the error in allowing alleged concerted action unsanctioned by an affirmative state regulatory policy, see text accompanying note 131 infra, to qualify for the McCarran exemption was probably harmless since there was no antitrust violation. On their facts at least, the decisions in Proctor, Royal Drug Co. v. Group Life \& Health Ins. Co., 556 F.2d 1375 (5th Cir. 1977), cert. granted, 98 S.Ct. 1448 (1978); Anderson v. Medical Serv., 1976-1 Trade Cases \ 60,884, aff'd mem., 551 F.2d 304 (4th Cir. 1977); Manasen v. California Dental Serv., 424 F. Supp. 657 (N.D. Cal. 1976), discussed in note 124 supra and accompanying text, all seem consistent with the concerns expressed in the text. Accord, Battle v. Liberty National Life Ins. Co., 493 F.2d 39 (5th Cir. 1974), cert. denied, 419 U.S. 1110 (1975) (funeral insurance plan held not exempt where 50-70\% of the funeral services industry was controlled and "unauthorized" funeral homes were treated unfairly). The only case that seems clearly wrong in not according insurers appropriate freedom to control costs is Hill v. National Auto Glass Co., 293 F. Supp. 295 (N.D. Cal. 1968), where the court said, without analysis, that the "business of insurance" did not include "securing for particular glass dealers the sales and installation jobs required by Allstate claimants." Id. at 296 . The court held, however, only that the McCarran exemption did not apply, not that there was a substantive violation.

131. As discussed in note 121 supra, legalization of monopsony has been suggested as a legitimate public policy response to a monopoly problem. For cases using the McCarran Act to uphold such a response to the problem of hospital costs by the Commissioner of Insurance in Pennsylvania, see Doctors, Inc. v. Blue Cross, 557 F.2d 1001 (3d Cir. 1976); Travelers Ins. Co. v. Blue Cross, 481 F.2d 80 (3d Cir. 1973); Frankford Hosp. v. Blue Cross, 417 F. Supp. 1104 (E.D. Pa. 1976), aff d per curiam, 554 F.2d 1253 (3d Cir.), cert. denied, 434 U.S. 860 (1977). In the Travelers case, Blue Cross had a $62 \%$ market share.

For a case holding exempt an alleged conspiracy of insurers to lower agents' commissions on the ground that state law contemplated "cooperation" on such matters and provided for regulation of rates, of which commissions were an element, see California League of Independent Ins. Producers v. Aetna Cas. \& Sur. Co., 175 F. Supp. 857 (N.D. Cal. 1959). This case and others reflecting the operation of insurer rate bureaus on aspects of the insurance business, see, e.g., Allstate Ins. Co. v. Lanier, 361 F.2d 870 (4th Cir.), cert. denied, 385 U.S. 930 (1966); Schwartz v. Commonwealth Land Tille Ins. Co., 374 F. Supp. 564 (E.D. Pa. 1974), would seem distinguishable from cases in which combinations of insurers attempt to exert their market power over the providers of insured services, whom state insurance regulators are normally not charged with protecting or controlling. In cases involving such spillover effects on noninsurance businesses, any exemption for an insurer cartel would have to arise not under the McCarran Act, but under the "state action" doctrine of Parker v. Brown, 317 U.S. 341 (1943), which exempts anticompetitive actions of private persons done by command of the state acting as a sovereign. The doctrine requires a strong and explicit state policy respecting the market in which the effect is felt. See Cantor v. Detroit Edison Co., 428 U.S. 579 (1976) (antitrust laws held to apply, in the absence of a clear state policy to the contrary, to electric utility's anticompetitive actions affecting the market for light bulbs, even though those actions were authorized by the state utility commission); Blumstein \& Calvani, State Action as a Shield and a Sword in a Medical Services Antitrust Context: Parker v. Brown in Constitutional Perspective, 1978 Duke L.J. 389. The Pennsylvania Blue Cross cases cited at the beginning of this footnote, though decided under the McCarran Act, should be viewed as applications of the Parker doctrine. The state's use of Blue Cross as a monopsonistic vehicle for controlling hospitals, though not truly within the scope of the private "business of insurance," was 
for insurers to take steps to offset the market-distorting effects of insurance and also for state regulators to authorize insurers to exert their monopsony power to offset the monopoly power of providers. ${ }^{132}$ Providers would have significant protection against unfair exploitation by private interests, and, by accepting the development of a more competitive and innovative insurance industry, could reduce the threat to themselves of state-sponsored monopsony, whether in the form of Blue Cross-Blue Shield plans ${ }^{133}$ or a federally dominated national health insurance program.

3. The Attractions of Private Measures to Control Costs. The cost-containment strategies suggested above, including the approach of organizing a panel of participating doctors, are fundamentally distinguishable from most of the innovative plans, particularly HMOs, which have incurred professional opposition in the past. Indeed, the suggested strategies specifically contemplate continuation of the fee-for-service mode of payment and the use of third-party insurance for the patient's financial protection. While anticipating a substantial departure from the passive insurer model, they nevertheless leave the doctor-patient relationship largely intact. The strategic use of coverage limitations to reintroduce the constraint of the patient's personal resources in appropriate circumstances would increase the necessity for the physician to act in a fiduciary capacity and to be professionally responsible for the patient's personal funds as well as his health. Under such a strategy, the insurer would in no sense be engaged in the "corporate practice of medicine," 134 because the patient would still look to his physician alone for medical advice and treatment. Any ethical objections that the medical profession might raise to such an approach would seem to reflect doctors' interest in preserving monopoly power more than legitimate

defensible as an exercise of state power. See Royal Drug Co. v. Group Life and Health Ins. Co., 556 F.2d 1375, 1382-83 (5th Cir. 1977), cert. granted, 98 S.Ct. 1448 (1978).

132. It seems unlikely that a state could be required under federal antitrust policy and the Parker doctrine, see note 131 supra, to adopt a less restrictive, procompetitive alternative approach to the control of a provider monopoly. But see note 133 infra. Nevertheless, the state's election to employ a monopsonistic regulatory strategy would have to be clear. See note 159 infra for a discussion of the possibility that insurers might combine under an insurance commissioner's auspices to negotiate doctors' fees.

133. Consistent with the analysis suggested in note 131 supra, an exploitative policy of a state government adopted without a colorable justification of a countervailing monopoly might conceivably be challengeable under the supremacy clause despite the Parker doctrine as inconsistent with the antitrust laws' procompetitive premise.

134. See Note, Controlling Health Care Costs Through Commercial Insurance Companies, 1978 DUKe L.J. 728. 
ethical concerns. ${ }^{135}$ As long as individual providers could elect voluntarily whether to participate in one or more competing plans, they could not complain that their independence was inappropriately eroded.

Because the suggested strategies could evolve naturally from existing insurance and practice patterns, a change in market conditions permitting the adoption of such strategies could have an immediate impact. If fear of professional retaliation could be obviated, health insurers should find cost controls less difficult to implement than the HMO concept, which requires a new organization, new capital, large start-up costs and numerous regulatory approvals. The prospect of lower insurance premiums would stimulate consumer interest in cost containment, aiding the process of educating consumers to the benefits of the proposed approach. Once competitive innovation and the education process have begun, the transition to a significantly restructured financing and delivery system should not take long. ${ }^{136}$

It is tempting but dangerous to try to evaluate the suggested costcontainment strategies in the abstract. Despite one's natural inclination to appraise their administrative feasibility and to estimate intuitively their acceptability both to individual providers and to consumers, such speculation is unreliable. Instead, the obvious complexity of the costcontainment task and the endless possibilities for combining strategies, for shaping the necessary administrative tools, and for enlisting providers' cooperation should suggest that testing and evaluation would best be undertaken in a competitive market. Not only are checks and balances always present in a competitive environment, but there are also constantly changing circumstances and a wide variety of individual attitudes and preferences which compel adaptation. Moreover, to increase receptiveness to cost-saving ideas, government could alter the operative incentives, particularly those flowing from the current tax treatment of health insurance premiums. ${ }^{137}$

135. Of course, physicians might raise the egalitarian notion that cost should never be a factor in consumers' decisions regarding medical services. But, not only is that proposition hard to defend, see Havighurst \& Blumstein 6-30, it is also hard to take seriously when it comes from a profession that is well paid for providing those services.

136. There are already signs that the private sector is responding to the cost crisis in interesting and innovative ways. See Council on WAGE \& Price STABILITY 99-177; text accompanying notes 66-69 supra.

137. See text accompanying notes 164-67 infra. For a proposal to change the method of subsidizing the purchasing power of persons requiring assistance, see Enthoven 710-713; Controlling Health Care Costs 476-77, 494 nn.20-21. 


\section{B. Other Unfavorable Factors in the Climate for Private Cost Containment.}

The medical profession has had many allies in its campaign to prevent fiscal concerns from intruding very far into decisionmaking on medical treatment. Indeed, some observers believe that a virtual consensus exists against most forms of cost containment that might be adopted in private third-party prepayment programs. ${ }^{138} \mathrm{It}$ would seem, however, that no such judgment can be made until the issue has been submitted to a definitive test of nonprofessional sentiment-a fair market test in which people face definitive choices, including the opportunity to benefit themselves directly by an economizing choice. The success of a number of HMOs (in the face of substantial obstacles) indicates that some forms of cost containment are acceptable and indeed are highly prized. Careful analysis will suggest that if such a consensus exists, it is artificial and subject to rapid breakdown if certain obstacles to competition in cost containment could be eliminated.

1. The Third-Party Payers. Among the medical profession's sometime allies on the cost issue are the third-party payers themselves. Although they are less passive today than in the past, neither the Blue Shield plans nor the commercial health insurers have pressed the doctors very hard or very often. Although recent innovations have been promising, performance still falls short of what is both administratively possible and required by the magnitude of the cost problem.

Due to their origin as creations of state medical societies and their continued domination by professional interests in many states, ${ }^{139}$ it is not surprising that Blue Shield plans have seldom been aggressive in-

138. On the general desirability of relying primarily on incentives rather than comprehensive regulation to solve policy problems, see C. Schultze, supra note 1. See also Altman \& Weiner, Regulating as a Second Best, in FTC 421. Considering the growth of comprehensive insurance, the practice of delegating decisionmaking to physicians without resource constraints or supervision, passiveness of insurers, and the limited value of cost-sharing and HMOs, Altmana and Weiner conclude that the market has no real future. Their analysis is based on a series of assumptions about consumer behavior, insurer behavior, the physician's role, political prospects for changes in the tax law and in the prevailing commitment to comprehensiveness in financing plans. Though the obstacles identified clearly exist, the assessment of insurmountability is questionable. Moreover, insofar as Altman and Weiner are assessing political prospects, their prophecies are apt to be self-fulfilling because policy advice that has already been discounted for political factors narrows rather than broadens the policy makers' perspective and range of options.

139. See Ohio v. Ohio Medical Indem., Inc., 1976-2 Trade Cases ๆ 61,128 (S.D. Ohio 1976); State Medical Soc'y v. Commissioner of Ins., 70 Wis.2d 144, 233 N.W.2d 470 (1975); Testimony of FTC Chairman Michael Pertschuk Before the Subcomm. on Oversight and Investigations of the House Comm. on Interstate and Foreign Commerce (Mar. 21, 1978) (with appendix showing control of individual plans) (copy on file at Duke Law Journat). 
novators in cost control. ${ }^{140}$ Originating more to assure payment for care rendered to lower-income patients than to serve consumer interests, ${ }^{141}$ Blue Shield plans may also have served-as the Oregon Physicians Service seemed to serve in the Oregon State Medical Society case-as role models for commercial health insurers, subtly teaching them their "place" and influencing their behavior toward doctors. ${ }^{142}$ Not surprisingly, Blue Shield plans have usually offered free choice among an open panel of physicians, whose participation agreements have not been onerous enough to discourage broad participation. ${ }^{143}$ The plans appear to have challenged physicians' spending decisions only rarely, and such review procedures as are used are dominated by practitioners lacking a reliable incentive to contain costs. ${ }^{144}$ Thus, when maximum charges are determined by the "usual, customary, and reasonable" fee formula, ${ }^{145}$ peer committees review all controversies that arise under the standard. ${ }^{146}$ In most places, Blue Shield has divided the health insurance market with the local Blue Cross plan, which provides more expensive hospital insurance without significant control over the physicians who prescribe the care for which Blue Cross pays. Despite occasional signs of independent behavior and innovation in the direction of cost containment, ${ }^{147}$ Blue Shield and Blue Cross plans are unlikely to deliver adequate cost containment to consumers. ${ }^{148}$

140. One should not be misled by cases brought by disgruntled physicians, such as Anderson v. Medical Serv., 1976-1 Trade Cases \ 60,884 (E.D. Va. 1976), aff'd mem., 551 F.2d 304 (4th Cir. 1977), into thinking that Blue Shield does not serve professional interests.

141. See H. Somers \& A. Somers, Doctors, Patients \& Health Insurance $317-22$ (1961); Kessel, Price Discrimination in Medicine, 1 J. L. \& Econ. 20, $32-33$ (1958). For an illustration of organized medicine's original conception of Blue Shield, see Master, Impact of Medical Care Plans on the Medical Profession, 150 J.A.M.A. 766 (1952).

142. See Goldberg \& Greenberg 58; see notes 42, 46, 50, 56-59, 61 supra and notes 280, 282, 285, 287-92, 295-96, 298 infra and text accompanying notes 42-61 supra and notes 279-98 infra.

143. See text accompanying notes 112-13 supra; Comment, supra note 47 , at 985-86 n.387. See also Anderson v. Medical Serv., 1976-1 Trade Cases \ 60,884 (E.D. Va. 1976), aff d mem., 551 F.2d 304 (4th Cir. 1977).

144. See Pertschuk testimony, supra note 139 (showing physician representation on committees); $c$. Havighurst \& Blumstein (discussing PSROs and their domination by physicians). 650.

145. This type of formula is widely regarded as being inherently inflationary. See Kallstrom

146. See Pertschuk testimony, supra note 139.

147. See text accompanying notes $68,112-13$ supra.

148. In many markets, especially where their competitive advantages and thus their market shares are large, the "Blues" act as kind of quasi-public agency, responding more to political than to market forces. Generalizations are thus dangerous because political climates vary, see note 131 supra, but it may be helpful to think of dominant Blue plans as analogous to independent regulatory agencies, with all the unreliability and risk of producer influence which that analogy implies. See generally S. LAW, supra note 121; R. Noll, Reforming Regulation (Brookings Inst. 1971). Cf. text accompanying notes 276-305 (implying a political role for the Blues in accommodating public and professional interests). 
There are several explanations for the failure of commercial health insurers to challenge physicians aggressively in pursuit of cost containment. The commercial companies often operate at distinct disadvantages in competition with the "Blues."149 Their competitive disadvantage and their vulnerability to boycotts appear to have caused the commercial insurers to accept the Blues' leadership on matters about which providers feel strongly and to direct their competitive efforts elsewhere. Thus, the commercial companies' most successful competitive challenges to the Blues have resulted from their greater ability to service national accounts and their greater willingness to use experience-rating for employment groups and cost sharing, comparative advantages whose implementation has not threatened providers' vital interests. ${ }^{150}$ Contracting only with insureds and not with providers, the commercial plans have lacked direct means of controlling providers' charges and behavior. Although adoption of certain panel-medicine models might be legally possible, ${ }^{151}$ steps in that direction have not been taken. Nor have other mechanisms for utilization control been developed. ${ }^{152}$ The only appreciable control efforts have focused on fees and on hospital charges to be paid. ${ }^{153}$ For a long time, the insurers made a positive virtue of noninterference in professional decisions, ${ }^{154}$

149. See S. LAW, supra note 121, at 11-13; Frech \& Ginsburg, Competition Among Health Insurers, in FTC 210.

150. The commercial companies' advantages in these three respects flow from the localized nature of the Blue plans (reflecting their organization by local provider interests), the Blues' preference for community rating (reflecting the original conception of the plan as a controlled, quasipublic taxing authority not facing competition), and the Blues' focus on shallow rather than catastrophic coverage (reflecting their origin as a means of assuring payment to providers). See H. Somers \& A. Somers, supra note 141, at 309-16. See generally J. KrizAY \& A. WiLSON, The Patient as Consumer: Health Care Financing in the United States 37-50 (1974).

151. See Note, supra note 134, at 750.

152. See note 158 infra for a discussion of practical difficulties confronting insurers. Insurers have cooperated with peer review mechanisms established by organized medicine, however. See, e.g., Steinwald, supra note 58, at 28; Edgahl, supra note 58, at 493.

153. See, e.g., Kallstrom 649-52. Obviously, insurers could not commit themselves to pay whatever the doctor charged, yet they were forced by competitive pressures from Blue Shield, which has some control over fees, to provide indemnification of incurred costs rather than a fixed cash indemnity.

154. It is the virture [sic] of the approach inherent in this insurance company concept

that there is no interference in the provision of care. Naturally, there are controls, the purpose of which is to define what is intended by the terms of the contract and to deter misuse of this intent. But the concept of insurance companies is that essentially any determination of the quality of care must rest with those professionally competent by training, tradition, and experience to arrive at such determinations-and with the patient.

Follman, Commercial Insurance Views Financing of Hospital and Medical Care, J. MicH. ST. MED. Soc'y, June, 1959, at 973, quoted in H. SOMERS \& A. Somers, supra note 141, at 415. For a full examination of insurer attitudes, their origins and their impact, see C. Morrow, Health CARE Guidance: Commercial Health Insurance and National Health Policy (1976). 
going along with physicians in interpreting as "interference" any aggressive attempt to impose insurance limits that cramped the doctors' style.

As discussed below, ${ }^{155}$ the commercial insurers' customers, primarily employers and labor unions, have not until recently demanded much cost containment, being largely content with traditional insurer practices. Because any attempt to sell cost containment aggressively would have required a large effort to educate both consumers and providers to a different view of the insurer's function, such competitive moves would have involved considerable investment and risks for the innovating insurer above and beyond the risk of probable professional retaliation. Moreover, any innovative success could have been quickly imitated by other insurers, touching off a competitive reaction which, insofar as it produced greater selectivity in benefit packages and reduced premiums, would reduce overall industry revenues. Given these risks, insurers are understandably hesitant to challenge the providers. ${ }^{156}$ It therefore seems likely that health insurers' lack of inventiveness in developing and promoting cost containment has rested in part upon a fear of the consequences of competition. ${ }^{157}$ In some respects, the medical profession appears to have done the health insurers a service by discouraging forms of competition that, while potentially beneficial to individual innovators and consumers, would have adversely affected the insurance industry as a whole.

Today health insurers strongly support cost containment, but they favor having government do much of the cost-containment job and disclaim the ability to do it themselves in a competitive environment. Maintaining that, as a highly fragmented industry, they lack the market power necessary to control costs and negotiate with providers, ${ }^{158}$ the

155. See text accompanying notes 164-69 infra.

156. Reflecting on the statement in note 154 supra, Herman and Anne Somers wrote: "Practical convenience often gets elevated to ideological status." H. SOMERs \& A. SOMERS, supra note 141 , at 415 See also C. MorRow, supra note 154, at 75-94.

157. Antitrust lawyers and economists will recognize the operation of "oligopolistic interdependence." See F. SCHERER, supra note 55, at 135-36; Posner, Oligopoly and the Antitrust Laws: A Suggested Approach, 21 StaN. L. REv.1562 (1969); Turner, The Definition of Agreement Under the Sherman Act: Conscious Parallelism and Refusals to Deal, 75 HARv. L. Rev. 655 (1962). When Dr. Paul Ellwood recently proposed the idea of "health care alliances," see text accompanying note 115 supra, the Health Insurance Association of America appointed a committee to consider it. One is inclined to wonder about the state of competition in an industry which responds to new ideas in this way.

158. One interpretation of this argument is that the individual insurer usually lacks bargaining power of the monopsonistic proportions needed to confront the physician monopoly. As argued in the text and in note 121 supra, however, it is not clear that permitting such monopsony power would be appropriate. Another more tenable interpretation of the insurers' position is that individual insurers frequently possess such a small share of the business in local markets that the 
commercial insurers have suggested expanding the insurance industry's antitrust exemption to permit them to bargain collectively with the medical profession. ${ }^{159}$ Whether congressional acceptance of this monopsonistic "solution" to the cost problem is appropriate depends, at least in part, on whether competitive innovation, along lines suggested herein, is feasible or not. It would seem that the principle of "countervailing power" should not be invoked unless it is clear that the provider monopoly cannot be broken down and reasonably competitive conditions restored. ${ }^{160}$

administrative costs of organizing provider panels and otherwise controlling costs would be prohibitive. An insurer whose market share was too small to permit operation on an efficient scale normally would either have to grow or to leave the business to others. The particular phenomenon here, however, may sometimes be the result of national contracts with large employers whose employees are scattered in pockets about the country. Present methods of providing coverage for such employers are not immutable, of course, and insurers should be expected to devise new ways of serving their national accounts, thereby solving the cost problem through innovation rather than adhering to traditional patterns. One possibility that suggests itself is that two or more insurers could combine their efforts in order to achieve the critical mass needed to organize a local panel; the business purpose of such a combination would probably protect the combination against antitrust attack if the plan did not try to do too much. See text accompanying notes 121-30 supra. See U.S. Dep't OF Justice, The PRICING AND MARKeTING OF INSURANCE 119-45 (1977), On the comparable problem of data exchange among insurers, deemed lawful under similar principles, see id. 91-119. Once the panel approach was established in a community, see text accompanying notes 114-17 supra, the panels would come to have an identity of their own and would compete to serve small accounts, relieving the insurers of the need to take the organizational initiative.

159. The insurers' proposal has not been made public in definitive form, but one statement by an insurance company executive suggests what they have in mind:

This would not enable us, for example, with the sort of limited legislation that I'm talking about, to have a group of insurance companies tell a group of doctors it's going to be this way or not at all. That's not the concept at all. It's rather to be able to sit down with a group of doctors and together find any reasonable way of having them accept reasonable and customary peer review and let their peer review be the last determinant whether they would be willing to accept that as a negotiated basis for payment in the area.

National Leadership Conference on America's Health Policy, Conference ProceedINGS 43 (1976). Although some concerted action can be justified, see note 158 supra, combinations for collective bargaining with physicians would violate fundamental antitrust principles. It is believed that the law allows sufficient flexibility to permit appropriate forms of innovation.

The health insurers apparently believe that a naked combination formed for purposes of collective bargaining with doctors would not be sheltered from antitrust scrutiny under the McCarran Act. Even if a state insurance commissioner blessed the arrangement, it would probably not receive McCarran protection unless the commissioner's actions could survive analysis under the Parker doctrine. See notes 131-33 supra.

160. Thus, rational policy would be to alter the tax treatment of health insurance premiums, see text accompanying notes 164-66 infra, and to enforce the antitrust laws before turning to more extreme solutions. Starr, supra note 121, appears to underestimate the potential for restoring the private market to health. European experience with collective bargaining is reported in W. Glaser, Health INSURANCE Bargaining: Foreign lessons for AMERICANS (forthcoming). The argument here is not that this model is unacceptable but that it is premature to adopt it. See note 121 supra. 
The health insurance industry's long-range economic interests do not lie in the direction of strengthened competition in cost containment or in restoration of their customers' cost-saving incentives, both of which would result in the elimination of excess insurance coverage and probably reduced premiums and profits for the industry as a whole. ${ }^{161}$ From the industry's point of view, the ideal outcome would seem to be the perpetuation of roughly the present system under more extensive public control mechanisms. The main pressure for cost containment would devolve on these public mechanisms rather than the insurers. If the controls were not very effective (as is likely ${ }^{162}$ ), the insurers would then enjoy the benefits of continued cost escalation without bearing any responsibility for it. But such an outcome would be politically unstable, giving rise to the likelihood that the health insurance industry would have its intermediary role assumed altogether by the federal government, promulgating fee schedules and otherwise wielding its monopsony power over providers to contain costs. The health insurers' proposal for a broader antitrust exemption to permit collective bargaining with providers appears to be a political strategy designed in recognition of just this possibility. Such an exemption would allow the health insurers to act in concert as a monopsonistic purchaser, obviating the necessity for government to exert its own monopsony power.

In pleading for dispensation from the basic antitrust prohibition against exploitative combinations of competitors, the insurers are not making their strongest case for a continued role in the health care system. Indeed, in a political gamble, they are playing away from what appears to be their greatest strength-namely their ability to offer consumers a meaningful range of choices and to accommodate, without coercion and through wholly consensual arrangements among individuals, the conflicting interests of consumers and providers. Although the insurers' proposal will be acceptable to those who view the health care crisis as a power struggle between provider and consumer interests, it still seems more appropriate to treat the problem as a potentially correctable failure of public policy and of the private market. In any event, the insurers' position on these issues must be seen for the self-interested political stance it is. Despite what they now say, health insurers probably can be counted on to compete in cost containment if they can be

161. Health insurers would probably not wish to see any change in the tax treatment of insurance premiums, but the introduction of tax credits for the underinsured, see text accompanying note 166 infra, might offset insurers' losses of premiums resulting from reductions in coverage by others.

162. See Havighurst, Health Care Cost-Containment Regulation, supra note 1. 
effectively deprived of their current excuses for not doing so. ${ }^{163}$

\section{The Customers: The Weakness of Demand for Cost} Containment. In addition to health insurers' reasonable fear of professional resistance, another explanation that can be offered for their slowness in initiating significant cost-containment measures in the past has been the lack of consumer demand for such programs. Employers and employee groups, particularly unions, have long sought increasingly comprehensive insurance protection and have revealed little interest in more selective coverage, high deductibles or cost controls that might limit patients' options.

The reasons for purchaser disinterest in cost containment are not difficult to identify. Cost escalation has been and is tolerated beyond consumers' actual preferences primarily because of the distorted incentives that result from the treatment of health insurance as a tax-free fringe benefit. ${ }^{164}$ This tax subsidy inflates the consumer's demand for health insurance and prevents employers and employees from deriving the full advantage of cost-containment efforts, the savings from which, if paid to the employee, would amount to wages subject to both income and Social Security taxes. More than any other factor, the tax law has prevented insurer competition from focusing on cost containment and has created the climate in which the medical profession's strong preferences concerning the nature of health insurance cannot be overcome. ${ }^{165}$

The prospects for private cost containment would brighten dramatically if insurance purchasers' cost consciousness were strengthened by a change in the tax law to make insurance purchaseable, beyond a certain point, only with after-tax dollars. ${ }^{166}$ Such use of financial incentives should seem an effective way to stimulate the education of employees to the frequently limited value of additional health care and to the desirablility of limited self-insurance over costly exposure to "moral hazard"-the risk that an insurance fund will be exploited by

163. But see C. MorRow, supra note 154. Morrow's pessimism about turning commercial insurers around on cost-containment issues might yield somewhat if she would consider the possible impact of changes in the competitive environment and in the operative incentives.

164. See Controlling Health Care Costs 475-78. Insurance unavoidably distorts many purchasing decisions, creating a problem that insurers must be induced to solve. The tax incentive to overinsure thus piles a distortion on a distortion, hopelessly entangling the system.

On the effect of tax considerations in union bargaining, see R. MUNTS, BARGAININo FOR HeALTH 87-88 (1967).

165. It is perhaps instructive that the greatest experimentation with new models of health care financing and delivery and the greatest confrontations between organized medicine and innovative health plans occurred before the era in which the tax law began to cushion the impact of insurance premiums. See note 50 supra.

166. For the proposal that a limited tax credit be substituted for the current form of tax subsidy, see Controlling Health Care Costs 476-77; Enthoven 711-12. 
the insureds (and the providers) if administrative checks are not imposed. If employers and unions could arrange for premium savings to flow through to employees without an additional tax, the latter would be induced (as they can be in no other way) to learn these important lessons. ${ }^{167}$

Despite the tax-induced weakness in private demand for cost containment, there is still an opportunity for insurers to respond to the limited but still significant desire for cost containment which exists at the new margin - where a dollar saved, though worth less than a dollar after taxes, may still be worth saving, depending on the value of the benefit forgone. Indeed, there are clear signs that employers and unions are awakening to the existence of inappropriate health care spending and to potential gains from cost containment. ${ }^{168}$ Moreover, insurers have taken many important initiatives which, although inadequate to meet the need and tentative in their approach to organized medicine, are indicative of immense promise. ${ }^{169} \mathrm{Far}$ from indicating that private cost containment has no future, current events indicate stirrings that could become a potent force if the threat of professional restraints on innovation could be removed.

\section{Antitrust Remedies for Professional Restraints}

Until recently, the antitrust laws have been of only slight value as a deterrent to restraints of trade by medical organizations. However, the Supreme Court's decisions in Goldfarb v. Virginia State Bar ${ }^{170}$ and Hospital Building Co. v. Trustees of Rex Hospital ${ }^{171}$ have significantly increased the likelihood of successful antitrust actions against professional groups by, respectively, establishing that the "learned professions" enjoy no special exemption ${ }^{172}$ and expanding the conception of

167. Employers and unions are reported to be highly paternalistic toward the rank and file, perferring liberal claims administration and comprehensive coverage even when the rational employee would prefer cost sharing, selective coverage, rigorous claims administration, and more take-home pay. Any problem here lies not with the health care system but in the areas of employee relations and internal union politics. See generally R. Munts, supra note 164. It seems clear that the public should not, through the tax system, underwrite the marginal costs of such paternalism. A tax law change would apparently contribute usefully to educating not only employees but also those who act as their proxies in decision making on health insurance. Also on consumer attitudes, see C. MORROW, supra note 154, at 87-93.

168. See Council on Wage \& Price Stability 99-177.

169. See references cited in note 80 supra.

170. 421 U.S. 733 (1975) (bar association mandatory fee schedule is unlawful price fixing).

171. 425 U.S. 738 (1976) (restraining expansion of 49-bed hospital would "substantially affect" interstate commerce and Sherman Act suit may be brought).

172. But see note 197 infra and accompanying text. 
interstate commerce to encompass more medical activities. ${ }^{173}$ Nevertheless, there remain a number of doctrinal and practical obstacles to making the antitrust laws an effective defender of innovation in the health services industry. The main focus of this legal analysis is on costcontainment innovations by third-party payers, but much of the discussion applies as well to HMOs and to competitive developments of other kinds in health care delivery.

\section{A. Professional Boycotts.}

The medical profession is ideally situated to employ boycotts to good advantage. By virtue of certain conditions in the medical marketplace, each fee-for-service physician already possesses a substantial measure of monopoly power over his or her individual patients, ${ }^{174}$ making it unnecessary for doctors to combine to forge new market power through price-fixing or market-division agreements. Instead, coercive refusals to deal and other techniques ${ }^{175}$ have been used to perpetuate those market conditions that underlie the individual doctor's market power and to frustrate both the efforts of consumers to combine for increased bargaining effectiveness and attempts by financing intermediaries to help consumers overcome their purchasing disadvantages. When used as a disciplinary technique, the boycott is effective in maintaining the status quo.

Unlike price fixing, professional restraints directed against consumer-oriented organizational innovations do not necessarily require unanimity or near-unanimity of action to be effective. Sporadic and incomplete boycotts can be quite successful in warding off periodic challenges. Moreover, the mere threat of harassment stemming from organized professional disapproval may prevent desirable initiatives from occurring at all, thus producing anticompetitive consequences without any overt action inviting antitrust enforcement. It would be desirable for antitrust law relating to professional boycotts and related restraints to be clarified in such a way as to deter both formal and in-

173. See text accompanying notes $256-57$ infra.

174. An individual doctor's considerable discretion in both pricing and spending results from several natural circumstances, inçluding patients' technical ignorance, their difficulty in shopping for alternative providers or treatments, and their reluctance to economize where health is allegedly concerned. In addition, the doctor's freedom in both pricing and choice of therapy is greatly enhanced by the frequent availability of third-party payment covering (within liberal limits) whatever fee the provider sets and many possibly nonessential services. See generally Sloan \& Feldman, Competition Among Physicians, in FTC 57.

175. Ethical restrictions on doctors' advertising are an example. See Canby \& Gellhorn, Phy. sician Advertising: The First Amendment and the Sherman Act, 1978 DukE L.J. 543, 546-47. 
formal abuses and to provide assurances of meaningful protection to would-be innovators.

1. Proving a Conspiracy to Boycott. A major impediment to the use of the antitrust laws to control professionally imposed restraints is the problem of proving, in particular cases, the existence of a "contract, combination ... o, or conspiracy" to boycott. ${ }^{176}$ Whether a boycott - that is, agreed-upon refusals to deal-organized by a professional group would be entitled to any special defenses will be discussed separately. For the moment, it may be assumed that a professional association's explicit call for its members to boycott an innovative provider or financing plan (or such a plan's subscribers or cooperating professionals) would be unlawful per se under established doctrine. ${ }^{177}$ Because it would be unusual to find documentation of an agreement or explicit invitation, however, it is important that enforcement mechanisms also be able to identify and deal with more subtle invocations of professional power.

The case law indicates that, where no agreement can be shown directly, an unlawful conspiracy to boycott can sometimes be inferred from collective actions likely to produce uniform behavior amounting to a boycott. Thus, the circulation of certain kinds of information likely to induce parallel action has been held to warrant a finding of a concerted refusal to deal. ${ }^{178}$ Without more, however, an inference of conspiracy would not be permissible if the information circulated was otherwise difficult to obtain and had value to the recipients above and beyond its utility as a signal for concerted action. ${ }^{179}$

Proof of widespread individual refusals to deal is not itself adequate to establish the requisite conspiracy; although true group boycotts to coerce private behavior are illegal per se, unilateral refusals to

176. Sherman Act § 1, 15 U.S.C. § 1 (1976).

177. See, e.g., Fashion Originators' Guild of America, Inc. v. FTC, 312 U.S. 457 (1941).

178. In Eastern States Retail Lumber Dealers' Ass'n v. United States, 234 U.S. 600 (1914), some retail lumber dealers' associations published a list of wholesalers who also traded at retail in competition with the associations' members. The Supreme Court said:

[W] hen in this case by concerted action the names of wholesalers who were reported as having made sales to consumers were periodically reported to the other members of the associations, the conspiracy to accomplish that which was the natural consequence of such action [i.e., refusals to deal] may be readily inferred.

Id. at 612 .

179. Cement Mfrs. Protective Ass'n v. United States, 268 U.S. 588, 604 (1925) (circulation among sellers of information regarding prices and quantities of cement sold under "specific job" contracts was upheld as a means to prevent buyers from fraudulently procuring more cement at the contract price than they were entitled to get); McCann v. New York Stock Exch., 107 F.2d 908, 912 (2d Cir. 1939). 
deal are permitted. ${ }^{180}$ Indeed, the freedom to do business with whomever one chooses is part of that same "freedom of traders" that the rule against coercive boycotts is itself designed to vindicate. ${ }^{181}$ Arguably, physicians might have good personal reasons for refusing to cooperate with a particular cost-containment program. Not only might the paperwork burden be seen as excessive, but an individual doctor might be so outraged by an insurer's action that he would be willing to give up some patients and some income to keep his conscience clear and to strike a small blow for patients' rights and professional independence. ${ }^{182}$ Where such motives are dominant, a conspiracy may not be inferable.

Although physician refusals to deal could sometimes occur without primary regard for what other doctors are doing, it may also be the case that, through the use of code words and signals, physician organizations can invite an outpouring of sentiment calculated to harass and thereby discipline an innovator. Numerous individual refusals to deal might therefore be decided upon with some expectation that others would act in parallel fashion, so that many more such refusals would occur than would have occurred without that expectation. ${ }^{183}$ Moreover, the role of a medical organization or of certain individuals in whipping up enthusiasm or in publicizing the issue and inviting the response may be apparent. A court or jury could, on facts suggesting such a scenario of stimulus and response, infer the existence of a conspiratorial boycott. ${ }^{184}$

180. See, e.g., United States v. Colgate \& Co., 250 U.S. 300, 307 (1919).

181. See Kiefer-Stewart Co. v. Joseph E. Seagram \& Sons, 340 U.S. 211, 213 (1951). It is perhaps noteworthy in this context that physicians appear to place a high value on their own freedom of choice. See Principles of Medical Ethics of the American Medical Association \& 5.

182. Such a defense would be more difficult to justify in the case of a refusal to refer patients to hospitals or specialists who are doing business with an HMO.

183. An inference of conspiracy from "conscious parallelism" is not compelled where the putative conspirators might have had reasons of their own for acting as they did, Theatre Enterprises, Inc. v. Paramount Film Distrib. Corp., 346 U.S. 537, 541 (1954), but neither would such an inference be improper. Arguable reasons for independent action should not preclude a factinder's inference of conspiracy where an element of interdependence remains. See notes 195-96, 271 infra. In the Theatre Enterprises case, the jury had found for the defendants, 346 U.S. at 539, but it is unlikely that a finding for the plaintiff would have been overturned. See text accompanying notes 208-11 infra.

184. In the $A M A$ case, the court of appeals sharply differentiated between the explicit boycotts there employed and intraprofessional communications of the sort that the text suggests may also be troublesome: "[A]ppellants have open to them always the safer and more kindly weapons of legitimate persuasion and reasoned argument, as a means of preserving professional esprit de corps, winning public sentiment to their point of view or securing legislation." 130 F.2d at 248 (footnotes omitted). Reference to "professional esprit de corps" might be read to imply that professional actions identifying an object of common concern would be acceptable so long as no retaliatory measures were explicitly advocated. The better reading, however, would permit profes- 
Despite this logic, the Oregon State Medical Society case ${ }^{185}$ suggests that the courts may not be quick to characterize professional activities as a boycott. ${ }^{186}$ There, the trial court had accepted the testimony of local medical society members that there was no society policy of discrimination against private hospital associations and had discounted evidence in the form of letters from doctors to hospital associations attributing their personal refusals to deal to "a policy of their local medical society." 187 The Supreme Court felt bound by these findings and theorized several possible innocent explanations for the letters. ${ }^{188} \mathrm{Nev}-$ ertheless, it certainly seems that messages were received by the medical society members even though none were demonstrably sent. Though the Court was unwilling to declare the trial court's refusal to find a conspiracy "clearly erroneous," its discussion of the evidence strongly suggests both the efficacy and the subtlety of intraprofessional commu-

sional groups to emphasize positive professional values but would encourage courts to regard with suspicion collective actions to denigrate alternative approaches or to focus professional disapproval on a specific competitor or would-be innovator.

185. See notes $42,46,50,56-57$ supra and text accompanying notes $42-57$ supra.

186. The Court's full discussion of the evidence on the boycott issue is helpful in dealing with the problem of proving a concerted refusal to deal in a professional setting:

The record contains a number of letters from doctors to private associations refusing to accept checks directly from them. Some base refusal on a policy of their local medical society, others are silent as to reasons. Some may be attributed to the writers' personal resistance to dealing directly with the private health associations, for it is clear that many doctors objected to filling out the company forms and supplying details required by the associations, and preferred to confine themselves to direct dealing with the patient and leaving the patient to deal with the associations. Some writers may have mistaken or misunderstood the policy of local associations. Others may have avoided disclosure of personal opposition by the handy and impersonal excuse of association "policy." The letters have some evidentiary value, but it is not compelling and, weighed against the other post-1941 evidence, does not satisfy us that the trial court's findings are "clearly erroneous."

Appellees' evidence to disprove conspiracy is not conclusive, is necessarily largely negative, but is too persuasive for us to say it was clear error to accept it. In 1948, 1,210 of the 1,660 licensed physicians in Oregon were members of the Oregon State Medical Society, and between January 1, 1947, and June 30, 1948, 1085 Oregon doctors billed and received payment directly from the Industrial Hospital Association, only one of the several private plans operating in the State. Surely there was no effective boycott, and ineffectiveness, in view of the power over its members which the Government attributes to the Society, strongly suggests the lack of an attempt to boycott these private associations. A parade of local medical society members from all parts of the State, apparently reputable, credible, and informed professional men, testified that their societies now have no policy of discrimination against private health associations, and that no attempts are made to prevent individual doctors from cooperating with them. Members of the governing councils of the State and Multnomah County Societies testified that since 1940 there have been no suggestions in their meetings of attempts to prevent individual doctors from serving private associations. The manager of Oregon Physicians' Service testified that at none of the many meetings and conferences of local societies attended by him did he hear any proposal to prevent doctors from cooperation with private plans.

If the testimony of these many responsible witnesses is given credit, no finding of conspiracy to restrain or monopolize this business could be sustained. Certainly we cannot say that the trial court's refusal to find such a conspiracy was clearly erroneous.

343 U.S. at 335-37. See also notes 199-200 infra and text accompanying notes 198-200 infra.

187. 343 U.S. at 335-36. See Goldberg \& Greenberg 61, for examples of such letters.

188. 343 U.S. at 335 . See note 186 supra. 
nication as well as the difficulty of curbing the profession's tendency to act in concert when its collective interests are threatened. ${ }^{189}$

The Oregon State Medical Society case, revealing a judicial reluctance to discover a physician boycott, is important authority, to be sure, but it is possible that in the years since 1952 we have become more sophisticated about the issues it addressed. ${ }^{190}$ Certainly the crisis in health care costs has highlighted the cost-escalating effects of thirdparty payment plans, providing one insight essential for an appreciation of the value of private cost-containment activity and of the hazards of excessive doctor influence over the mechanisms of health care financing and delivery. ${ }^{191}$ More specifically, the work of Goldberg and Greenberg which reinterpreted the Oregon experience ${ }^{192}$ revealed how doctors' refusals to deal, stimulated at least in part by professional actions taken in concert, can suppress independent efforts to curb physicians' power. Moreover, despite the Supreme Court's dicta in the Oregon and Goldfarb cases indicating that professionals' activities would be viewed charitably, ${ }^{193}$ the antitrust and other scrutiny to which various professional actions are currently being subjected ${ }^{194}$ may dispel some of the illusions about professionals that have prompted the Court to hedge its opinions in the past. In particular, enough evidence may be accumulating on physicians' conduct to confirm the impression that, far from being entitled to judicial deference, the medical profession has a sufficient propensity for concerted action in defense of its economic in-

189. See note 186 supra. The Court concluded from evidence that two-thirds of the Oregon physicians had accepted payments directly from one of the hospital associations in one 18-month period that the boycott, if indeed one had been attempted, was ineffective. 343 U.S. at 336. By another measure of effectiveness, however, the medical societies' actions were highly successful, since the hospital associations terminated their objectionable methods of cost containment. See Goldberg \& Greenberg 61.

190. As a sign of the difference in the times, it is notable that the trial judge's findings of fact, by which the Supreme Court felt bound, contained, as the Court observed, "irrelevant soliloquies on socialized medicine, socialized law, and the like, which . . . do not add strength or persuasiveness to his opinion." 343 U.S. at 331.

191. In retrospect, it seems that the target in Oregon State Medical Society should have been not the unprovable conspiracy to boycott but the concerted actions involved in creating the profession's own prepayment plan. It was this initiative that facilitated more uniform resistance to the hospital associations. Subsequent discussion, at text accompanying notes 279-98 infra, examines more fully the case for using the antitrust laws to prevent profession-dominated "reforms" from foreclosing private innovation.

192. Goldberg \& Greenberg.

193. See note 197 infra and text accompanying notes $197-98$ infra.

194. See, e.g., National Soc'y of Professional Eng'rs v. United States, 98 S.Ct. 1355 (1978) (ethical restraint on competitive bidding held a per se violation); Bates v. Arizona State Bar, 433 U.S. 350 (1977) (disciplinary restraint on attorney advertising held unconstitutional). Goldfarb and Bates strongly reflect an increased awareness by the Court of the interests of consumers in a properly functioning competitive market. 
terests that special vigilance is required. ${ }^{195}$ In cases where doctors' interests have been challenged, courts should not make themselves hard to persuade that there has been a meeting of professional minds. ${ }^{196}$

2. Professionalism as a Defense for Boycotts. Even though Goldfarb held that the so-called "learned professions" are subject to the antitrust laws, that case also suggested that the concept of professionalism may legitimize certain collective activities by professional societies that would not be permitted if undertaken by industrial trade associations. ${ }^{197}$ An even broader indication of this possibility appeared in Oregon State Medical Society:

Since no concerted refusal to deal with private health associations has been proved, we need not decide whether it would violate the antitrust laws. We might observe in passing, however, that there are ethical considerations where the historic direct relationship between patient and physician is involved which are quite different than the usual considerations prevailing in ordinary commercial matters. This Court has recognized that forms of competition usual

195. Though comprising a large number of seemingly independent competitors, many of them in solo practice, the medical profession possesses remarkable solidarity. Not only is there considerable interdependence as a result of referral patterns, hospital practice and professional organizations, but also the training of physicians, long dominated by organized medicine through its accreditation powers, see generally Kessel, Higher Education and the Nation's Health: A Review of the Carnegie Commission Report on Medical Education, 15 J. L. \& EcoN.115 (1972); see note 240 infra, has instilled many common values and perceptions that make it relatively easy to stimulate a collective response to a perceived threat, once identified. For a discussion of the ideological cohesiveness of the medical profession, see note 214 infra. Moreover, informal professional and social interactions among physicians in many communities facilitate the enforcement of consensual expectations, once arrived at, against all but the profession's fringe. See Brief for Appellants at 3-28, Feminist Women's Health Center v. Mohammad, 415 F. Supp. 1258 (N.D. Fla. 1976); see notes $39-40$ supra.

196. In other industry settings involving large numbers of competitors, the Supreme Court has been willing to discover conspiracies without precise proof of the mechanisms by which they were controlled. Thus the Court has observed that, among a cartel's sanctions, "experience has shown [business honor and social penalties] to be the more potent and dependable restraints." American Column \& Lumber Co. v. United States, 257 U.S. 377, 411 (1921). In another case, involving a price-fixing plan by real estate brokers that lacked visible enforcement mechanisms, the Court observed: "Subtle influences may be just as effective as the threat or use of formal sanctions to hold people in line." United States v. National Ass'n of Real Estate Bds., 339 U.S. 485,489 (1950). On the significance of exchanges of assurances among professionals with a strong awareness of their collective welfare, see note 271 infra and accompanying text. See also note 214 infra and text accompanying notes 217-33 infra.

197. 421 U.S. at 788 n.17:

The fact that a restraint operates upon a profession as distinguished from a business is, of course, relevant in determining whether that particular restraint violates the Sherman Act. It would be unrealistic to view the practice of professions as interchangeable with other business activities, and automatically to apply to the professions antitrust concepts which originated in other areas. The public service aspect, and other features of the professions, may require that a particular practice, which could properly be viewed as a violation of the Sherman Act in another context, be treated differently. We intimate no view on any other situation than the one with which we are confronted today. 
in the business world may be demoralizing to the ethical standards of a profession. ${ }^{198}$

While this dictum stands as a general expression that the medical profession may enjoy certain prerogatives, the case law has yet to establish what those prerogatives might be. ${ }^{199}$

There is no question that the foregoing quotation from the Oregon case, when read in the context of the Supreme Court's discussion of the boycott issue, ${ }^{200}$ strongly implies that the medical profession might be allowed to engage in coercive boycotts, enforcing professional "ethics" against third-party insurance carriers and others. One cannot know for certain, of course, whether the Court would in fact tolerate such action, but, given its strongly expressed opposition in other contexts to "agreements ... [which] cripple the freedom of traders and thereby restrain their ability to sell in accordance with their own judgment,"201 it would be surprising if the medical profession were allowed to enforce its preferences by such coercive means. Moreover, such a result would depart widely from the holding in the $A M A$ case, in which the court of appeals held that the doctor conspiracy to boycott Group Health and its participating doctors could not be defended on the basis that it was "intended to promote the public welfare" or "designed to eliminate unfair, fraudulent and unlawful practices." 202 Underscoring its view concerning the limits of professional power, the court of appeals observed that "[A]ppellants are not law enforcement agencies . . . and although persons who reason superficially concerning such matters may find justification for extra-legal action to secure what seems to them desirable ends; this is not the American way of life."203 This language seems more in keeping with established antitrust doctrine and more manageable as a principle than the dictum in the Oregon case. Moreover, the Supreme Court's recent refusal to listen to any worthy-purposes de-

198. 343 U.S. at 336.

199. The most recent decision of the Supreme Court suggests that professionalism may not make an appreciable difference. In National Soc'y of Professional Eng'rs v. United States, 98 S.Ct. 1355 (1978), a majority of the Court stated that "professional services may differ significantly from other business services, and, accordingly, the nature of the competition in such services may vary. Ethical norms may serve to regulate and promote this competition, and thus fall within the Rule of Reason." Id. at 1367. Justice Blackmun, joined by Justice Rehnquist, expressed the fear that the majority's emphasis on competition as the touchstone, which it drew from a historical review of the rule of reason, left too little "elbow room for realistic application of the Sherman Act to professional services." Id at 1370 . The Professional Engineers case significantly narrows the implication of the Goldfarb footnote quoted in note 197 supra.

200. The quoted language appears precisely at the ellipsis in the lengthy quotation set forth in note 186 supra.

201. Kiefer-Stewart Co. v. Joseph E. Seagram \& Sons, Inc., 340 U.S. 211, 213 (1951).

202. 130 F.2d at 249.

203. Id. 
fense for a professional ethic barring competitive bidding by consulting engineers goes very far toward subjecting professional groups to the usual rules of per se illegality. ${ }^{204}$

Other cases that have grappled with the professionalism defense for boycotts have not departed from the usual stringent standards. One recent case upheld a complaint alleging that a dentists' organization induced certified orthodontists not to teach in the plaintiff's innovative training program in orthodontics. ${ }^{205}$ The court stressed that the defendant not only refused to accredit the plaintiff's training program but also enforced its disapproval by an ethical rule binding on its members. Thus, a classic concerted refusal to deal was alleged, and, although it was not characterized as a boycott by the court, it was condemned without any apparent hope of redemption by proof of worthy goals. ${ }^{206}$ Another court, in dealing with an alleged conspiracy among hospitals and a certifying organization for respiratory therapists, stressed the necessity for distinguishing between "commercial" and "noncommercial" boycotts, indicating a willingness to treat the former as per se illegal and to condemn the latter only if they were "unreasonable (in the antitrust sense) in their impact." ${ }^{207}$ Since both of the foregoing cases indicated a willingness to consider the probable anticompetitive impact of the restraint rather than its allegedly high-minded objectives as the key factor, they seem to leave the law of professional boycotts in very much the same posture as the law of boycotts by other competitor groups.

Though hardly authoritative, perhaps the most interesting decision on the value of professionalism to insulate a classic boycott was reached by a divided FTC in a 1966 case in which medical and hospital interests were found to have unlawfully boycotted two commercial blood banks. ${ }^{208}$ As the two dissenting commissioners noted, no commercial motive appeared, ${ }^{209}$ only an ideological objection to "traffick-

204. National Soc'y of Professional Eng'rs v. United States, 98 S. Ct. 1355 (1978).

205. United States Dental Inst. v. American Ass'n of Orthodontists, 396 F. Supp. 565 (N.D. III. 1975). Compare Marjorie Webster Jr. College, Inc. v. Middle States Ass'n of Colleges \& Secondary Schools, Inc., 432 F.2d 650 (D.C. Cir.), cert. denied, 400 U.S. 965 (1970) (no boycott involved in educational association's choice to adopt non-profit status as a requirement for accreditation).

206. 396 F. Supp. at 581. The court's recognition of the anticompetitive consequence of the alleged practice-denial to general practitioners of training in orthodontics that would enable them to compete with members of the defendant specialty society-was undoubtedly a factor in the holding. 1977).

207. Veizaga v. National Bd. for Respiratory Therapy, 1977-1 Trade Cases 161,274 (N.D. Ill.

208. Community Blood Bank, Inc., 70 F.T.C. 728 (1966), rev'd on other grounds, 405 F.2d 1011 (8th Cir. 1969).

209. Id at 955-58 (Comm'r Elman, dissenting); id. at 962 (Comm'r Reilly, dissenting). 
ing in human blood" and a professional concern (seemingly sincere, though undocumented) about the quality of blood supplied. ${ }^{210}$ Despite these reasons why individuals might have independently eschewed dealings with the commercial suppliers, the majority was willing to infer a conspiracy by emphasizing this shared belief together with evidence of regular meetings, discussions of the commercial banks as a problem to be solved, several affirmative acts in furtherance of the common purpose, and consistently parallel behavior. Significantly, the majority, unlike the minority, was unwilling to allow a boycott, even one inspired by seemingly legitimate professional values, to victimize an innovative provider. ${ }^{211}$

Aside from the dictum in the Oregon case, there seems to be no authority allowing professional groups greater freedom than other competitor combinations to employ boycotts to coerce the actions of independent participants in the market for health or other professional services. As in other fields, per se illegality is most appropriate where the boycott's impact is felt by a competitor or competing group. ${ }^{212} \mathrm{Al}-$ though a different approach might be taken where agreed-upon refusals to deal are directed at some perceived abuse not involving the commercial interests of the boycott organizers, a physician boycott directed at a third-party insurer should fall into the forbidden category as a "commercial" restraint even though the insurer is not, strictly speaking, a competitor of the doctors. No meaningful distinction exists between attempted destruction of a competitor, such as Group Health in the $A M A$ case, and destruction of the benefits of competition by dictating the terms on which dealing will occur. ${ }^{213}$ Indeed, the restraint alleged in the Oregon case was serious not because the insured hospital

210. On appeal, the lack of a demonstrated commercial purpose was held effectively to deprive the FTC of jurisdiction over the nonprofit corporations involved since they had not been shown to be organized for the profit of their members as required by 15 U.S.C. $\$ 44$ (1976). 405 F.2d at 1019. This technical issue aside, however, such ideological purposes should not be accepted as a justification for a boycott where their effect is to stifle a competing enterprise or otherwise further the parochial interests of the profession. See note $214 \mathrm{infra}$. While first amendment considerations may be invoked to protect intraprofessional communications and the propagation of professional ideology, first amendment values may also advanced in defense of pluralism and against private repression of competing ideologies. See text accompanying notes 224-31 infra.

211. An important feature of the case was that the Community Blood Bank, though long the subject of discussion, was organized only upon the appearance of the commercial bank. 70 F.T.C. at 777-78. Clearly, if established providers can employ the boycott weapon, the competitive stimulus to change, such as was needed to improve blood banking in Kansas City, would be repressed.

212. L. Sullivan, Handbook of THE Law of ANTITRust 238-41 (1977). See Note, Boycoll: A Specific Definition Limits the Applicability of a Per Se Rule, 71 Nw. U.L. REv. 818 (1977).

213. For cases in which boycotts were employed to dictate the terms of dealing, see Paramount Famous Lasky Corp. v. United States, 282 U.S. 30 (1930); United States v. First Nat'l Pictures, Inc., 282 U.S. 44 (1930). 
associations were competitors of Oregon Physicians Service but because they were vehicles for improving the consumer's bargaining position vis-a-vis the doctors and for containing the artificial demand for doctors' services generated by insurance. Probably the key to finding a per se violation should be the presence of a possible conflict of interests on the part of the boycott organizers, who should not be entrusted in such circumstances, even as professionals, with the economic power inherent in the boycott sanction. ${ }^{214}$

214. Under this test, the Community Blood Bank case, discussed in notes 210-11 supra and text accompanying notes 208-11 supra, was correctly decided by the FTC. Though the majority did not find a commercial purpose, a conflict of interests might nevertheless have been identified in view of the pathologists' interest in running their own departments and in sharing authority over the community bank.

To illustrate the difficulty of disentangling commercial and noncommercial purposes, imagine a medical society resolution declaring it unethical for any member to prescribe Laetrile (assumed for present purposes to be a medically useless but hope-inspiring drug) for cancer patients. This would amount to a boycott of Laetrile suppliers, who are in a significant sense competitors of physicians because adopting Laetrile therapy implies foregoing the more expensive cancer therapies that physicians offer. On the other hand, because Laetrile therapy is offensive to important professional values and because the suppliers of Laetrile are apt to be regarded by physicians as unethical profiteers, any commercial motive is clearly dominated by other concerns. Nevertheless, these concerns may be strengthened by the competitive threat posed, and one could question whether, given the conflict of interests, the medical profession's positions on such issues could ever be wholly objective. More importantly, there is an ideological issue as well on which professional views appear to differ from the views of many others. An alternative conception of the ethical responsibility of the physician might be that a patient can have Laetrile prescribed if that is his choice following an exposition by the physician of the alternatives available and the risks of the treatment. Under this formulation, some individual professionals might refuse ever to prescribe Laetrile, while others might do so in good conscience when the patient's choice was an informed one; professional organizations would be justified in disciplining individual physicians who failed adequately to inform patients of the risks to which they were exposing themselves. This latter conception of professional responsibility is perhaps more in keeping with the principle of consumer sovereignty reflected in the antitrust laws than is the impulse of many physicians to prescribe a rule for all physicians, effectively cutting off certain options that patients might wish to adopt.

The foregoing illustration presents sharply the ideological dimension that frequently exists in professional self-regulation, see also note 195 supra, and suggests the appropriateness of not respecting ideological boycotts where a conflict of economic interests is also present. It should not be necessary to impugn the medical profession's actual motives since the principle that a conflict of interests automatically disqualifies a decision maker is an objective one, as is the principle that consumer choice rather than professional choice should ultimately govern medical practice. See note 225 infra; Canterbury v. Spence, 464 F.2d 772 (D.C. Cir.), cert. denied, 409 U.S. 1064 (1972) (informed consent); Note, Restructuring Informed Consent: Legal Therapy for the Doctor-Patient Relationship, 79 YALE L.J. 1533 (1970). On other ideological issues in medical practice that are subject to foreclosure by the physician monopoly, see note 210 supra and accompanying text; A. Dolan, Antitrust Law and Physician Imposed Restraints on Patient Choice of Practitioners (Dec. $19,1977)$ (presented at the Antitrust Laws and the Health Services Industry, a conference sponsored by the American Enterprise Institute for Public Policy Research, and Duke Law Journal) (discussing "therapeutic ideology"); Havighurst \& Bovbjerg, supra note 1, at 401-11; Havighurst \& Blumstein; Comment, Restrictions on Unorthodox Heallh Treatment in California: A Legal and Economic Analysis, 24 U.C.L.A. L. REV. 647 (1977). 


\section{B. Practices Conducive to Boycotts.}

1. Applying the Boycott Label. Although coercive boycotts used to advance professional groups' commercial interests appear to be illegal per se, confusion can exist concerning whether a true boycott exists. It is tempting, for example, to attach the boycott label to any exertion of a competitor group's power which seems unreasonable even though, on close inspection, there have been no agreed-upon refusals by competing buyers or sellers to deal with particular third parties. ${ }^{215}$ To avoid confusion in the field of professional restraints, however, it seems desirable to reserve the boycott label for true concerted refusals to deal and not to extend this particular category of per se offenses beyond its literal limits. Although such a precise definition of the per se offense would leave the legal status of many other coercive and potentially destructive practices unresolved, many of these practices might be condemned by a different and only slightly more extended analysis. Thus, concerted action conducive to, or closely analogous to, a true boycott might be readily condemned in an appropriate case by consulting precedent, quickly applying the "rule of reason," and finding the practice to be anticompetitive and, while not technically a boycott, equally destructive and equally unredeemable by any possible showing of worthy purpose or minimal impact. ${ }^{216}$

An example of a practice that falls near the borderline between a true boycott and a restraint requiring a somewhat fuller evaluation would be a medical society resolution condemning a health insurer's adoption of a particular cost-containment practice. If the resolution included a call for members to cease or alter their dealings with the insurer in question, it would be illegal per se. ${ }^{217}$ Even without such an explicit invitation, however, a conspiracy to boycott might still be inferred simply from the circulation of the profession's official opinion, which serves no useful purpose other than to educate members as to their collective self-interest, increasing the likelihood of refusals to deal or other harassment. ${ }^{218}$ Alternatively, the resolution could be found,

215. The Supreme Court has always been clear on the distinction between a true concerted refusal to deal, or boycott, and other practices that are similar but nevertheless do not amount to a boycott. Some confusion exists, however, among commentators. See note 235 infra.

216. As Areeda observes, "[t]here are cases where one can weigh harms, benefits, and alternatives and conclude almost instantaneously that conduct is unlawful; one decides the particular case so rapidly that he may express his result in "per se' language." P. AREEDA, supra note 128, at 409.

217. For an example of such a resolution, see note 68 supra and accompanying text.

218. The matter could be seen as falling under the principle of the Eastern States case. See note 178 supra and accompanying text. See also Vandervelde v. Put and Call Brokers and Dealers Ass'n, 344 F. Supp. 118, 139-42 (S.D.N.Y. 1972). That the medical profession relies on educating 
whether or not indicative of an actual conspiracy to boycott, to restrain unduly the insurer's freedom to act in accordance with its own business judgment concerning consumers' desires for cost-containment services. The hazard that doctors would be stimulated to refuse to deal in greater numbers could easily outweigh any public benefit that might flow from the declaration of a professional consensus. ${ }^{219}$

\section{Confronting the "Free Speech" Argument: The Noerr-Penning-} ton Doctrine. The suggestion that professional organizations become exposed to antitrust liability by formulating and announcing an opinion on business developments affecting their members' welfare will naturally be threatening and potentially frustrating to medical society activists. They can be expected to contest the reach of antitrust into their organizational affairs by asserting rights of free speech and association as embodied in what has become known as the Noerr-Pennington doctrine. ${ }^{220}$ This doctrine sets limits derived from values implicit in the first amendment on the use of antitrust rules to control concerted action by competitors when political rights would be infringed.

its members to their common interests is implied by the motto of the AMA's newspaper, American Medical News: "An Informed Membership Is Our Greatest Strength." It must be observed, however, that certain recent AMA resolutions critical of third-party initiatives have not been widely circulated or announced in such a way as to encourage doctors to retaliate. See, e.g., Blues' Policies Opposed, Am. Med. News, Dec. 12, 1977, at 7, col. 1. Nevertheless, since such issues arise locally, and not nationally, local medical societies might use the AMA resolution in formulating their strategies in local skirmishes with insurers.

219. Arguably, it would not matter whether such refusals were for personal reasons or in defense of collective interests. In United States v. Container Corp., 393 U.S. 333 (1969), the casual exchange of price information by leading producers in a somewhat concentrated market was held unlawful without evidence of purpose and without significant inquiry into actual effects. Concerted action having dangerous tendencies and little redeeming value can be condemned under standard principles without demonstrating actual effects or wrongful intent in specific cases.

220. See generally Fischel, Antitrust Liability for Attempts to Influence Government Action: The Basis and Limits of the Noerr-Pennington Doctrine, 45 U. CHI. L. Rev. 80 (1977); Note, Physician Influence: Applying Noerr-Pennington to the Medical Profession, 1978 DuKE L.J. 701. In the leading case, Eastern R.R. Presidents Conference v. Noerr Motor Freight, Inc., 365 U.S. 127 (1961), the Supreme Court refused to allow the antitrust laws to be used to restrict the railroads' deceptive use of the media to procure legislation adverse to trucking interests, arguing, in effect, that the "marketplace of ideas" could take care of itself. Similarly, it was held in UMW v. Pennington, 381 U.S. 657 (1965), that the petitioning of government officials-the Secretary of Labor in that case-to adopt policies harmful to competitors was privileged against antitrust action. A later decision, however, upheld an antitrust complaint that charged a truckers' association with abusing the fundamental right of access to the administrative and judicial arms of government by systematically opposing before a state regulatory commission and the courts, without regard to the merits, all applications for new entry into the trucking business. California Motor Transp. Co. v. Trucking Unlimited, 404 U.S. 508 (1972). Despite the argument that the established truckers were simply petitioning their government, the case was held to fall within the "sham" exception, see text accompanying note 224 infra, to the general principle that antitrust should not frustrate the exercise of political rights. 
The Noerr-Pennington line of cases protects a trade association and its members when they are in some sense petitioning government in good faith. However, when a medical society or hospital staff involves itself in activities where it is not petitioning government and where it has no quasi-governmental function of its own, ${ }^{221}$ it would appear to be subject to antitrust controls and to all the rigors of the antiboycott rule. Thus, where medical society discussion arouses antagonisms leading to a boycott of an insurer or an innovative provider, it is private, not governmental, behavior that the medical society seeks to change, and an antitrust prohibition against such coercion is quite in keeping with a constitutional order which distinguishes between public and private spheres. Under antitrust doctrine, the basic objection to the use of the boycott sanction is precisely that it represents an assumption of governmental power by a private group and "trenches upon the power of the . . . legislature."222 Professional groups lacking a clear delegation of governmental power ${ }^{223}$ must not be allowed to assume such authority.

Of course, a medical society might cast all of its anticompetitive moves in political terms, sending its signals to the membership in the form of a complaint that "there ought to be a law" against whatever some third party was doing. But such an attempt to disguise a call for boycott as political speech would face a severe test under the "sham" exception to the Noerr-Pennington doctrine, which the Supreme Court stated as follows:

221. In Feminist Women's Health Center, Inc. v. Mohammad, No. 75-186 (N.D. Fla., Dec. 3, 1976), the district court refused to give practically any weight to antitrust considerations in granting summary judgment to hospital physicians who had acted to stifle a competing abortion clinic. Reversing its own earlier position, 415 F. Supp. 1258 (N.D. Fla. 1976), the court ruled that, by virtue of a vague statutory mandate to engage in professional self-regulation, hospital staffs are always engaged in quasi-governmental activity, so that intraprofessional communications are privileged. The court then concluded that even proven anticompetitive motives could not taint the activities of the hospital staff taken in the name of professional standards unless "a pattern of baseless, repetitive claims exists, so pervasive that from its very magnitude the inference of abuse of the governmental process emerges." No. 75-186, slip op. at 4 (N.D. Fla., Dec. 3, 1976). By that standard, almost any intraprofessional communication could not be evidence of conspiracy as long as ethics, the quality of care, or some other professional value was invoked. In addition to the inadequate weight given to antitrust considerations, a further difficulty with the case is that the allegedly quasi-governmental actions of the medical staff were taken without investigation and without any procedural formalities whatsoever, thereby seemingly violating the doctrine of Silver v. New York Stock Exch., 373 U.S. 341 (1963). See text accompanying notes 246-47 infra.

222. Fashion Originators' Guild v. FTC, 312 U.S. 457, 465 (1941) (quoting Addyston Pipe \& Steel Co. v. United States, 175 U.S. 211, 242 (1899)).

223. In keeping with the usual principle that antitrust prohibitions should not be deemed set aside without a clear indication of legislative intent, see, e.g., Silver v. New York Stock Exch., 373 U.S. 341, 357 (1963), the delegation to a professional group should be clear and specific, as it was not in the Feminist Women's Health Center case, discussed in note 221 supra. 
There may be situations in which a publicity campaign, ostensibly directed toward influencing governmental action, is a mere sham to cover what is actually nothing more than an attempt to interfere directly with the business relationships of a competitor [in which case] the application of the Sherman Act would be justified. ${ }^{224}$

Professional groups might claim a first amendment right to pursue "noncommercial" objectives and could cast their objections to many third-party activities and new forms of competition in terms that defy both characterization as commercially inspired and attribution of an anticompetitive motive. ${ }^{225}$ Nevertheless, where the speech does not take the form of an appeal for political action, such as appeared in the Noerr and Pennington cases, first amendment imperatives are weaker, and countervailing interests must be given their appropriate weight. ${ }^{226}$

224. 365 U.S. at 144. For cases in which the exception has been applied, see note 179 supra and United States v. Otter Tail Power Co., 360 F. Supp. 451 (D. Minn. 1973), aff'd, 417 U.S. 901 (1974). In such cases, there is apparently no avoiding an inquiry into subjective intent. See note 225 infra. Somewhat comparable issues have arisen in labor cases which involve such questions as whether the purpose of picketing is to convey information to the public or to signal other unions to exert pressure, and whether employer speech is intended to intimidate the workers. American Radio Ass'n v. Mobile S.S. Ass'n, 419 U.S. 215 (1974) (signal picketing); NLRB v. Gissel Packing Co., 395 U.S. 575, 619 (1969) (employer intended to threaten workers).

225. Where noncommercial purposes do indeed motivate the exchange of views and the resulting parallel behavior, a difficult problem of balancing the strong interest in free discussion against interests in freedom from economic coercion is presented. See Note, Political Boycott ACtivity and the First Amendment, 91 HARV. L. REv. 659 (1978). However, where a commercial motive underlies the discussion, the balance would seem to shift in a fundamental way, with the public's interest in free economic activity becoming paramount. See generally Bird, Sherman Act Limitations on Noncommercial Concerted Refusals to Deal, 1972 DukE L.J. 247; Coons, Non-Commercial Purpose as a Sherman Act Defense, 56 Nw. U.L. Rev. 705 (1962). An objective test based on conflict-of-interests principles would be preferable to a subjective test focusing on the content of the speech in question or the actual intent of the speakers. See note 214 supra. This is, roughly speaking, the rule that has evolved for businessmen, and it has proved salutary in avoiding complexities, in facilitating enforcement and in removing the temptation to hide a restraint behind a claim of worthy purpose. Any different rule for professionals, such as is suggested by a taxonomy which attributes commercial purposes only to "businessmen," see Bird, supra, at 249-50; Coons, supra, at 712, 726-29 \& 727 n.64; Note, supra, at $660 \mathrm{n} .11$, would sacrifice these advantages. Moreover, despite dicta seeming to concede that professionals' concerns rise above the commercial level, see note 197 supra and text accompanying notes 197-98 supra, the courts have seen many cases where they have not done so. See notes 206, 210-11 supra and text accompanying notes 1617, 205-11 supra, suggesting that no dispensation is appropriate. See Bird, supra, at 268-70.

For a case sometimes cited as adopting noncommercial purpose as a Sherman Act defense, see Marjorie Webster Jr. College, Inc. v. Middle States Ass'n of Colleges \& Secondary Schools, Inc., 432 F.2d 650 (D.C. Cir.), cert. denied, 400 U.S. 965 (1970). That case did not involve a boycott, however, or any danger thereof.

226. Recent cases holding for the first time that so-called "commercial" speech is entitled to first amendment protection make it clear that some regulation is still permissible and suggest that a simple balancing test is to be employed. Bates v. Arizona State Bar, 433 U.S. 350 (1977); Virginia State Bd. of Pharmacy v. Virginia Citizens Consumer Council, Inc., 425 U.S. 748 (1976); Bigelow v. Virginia, 421 U.S. 809 (1975). These cases all involved advertising of professional services, and a dominant consideration in extending constitutional protection to such speech was the interest of consumers in receiving the information sought to be conveyed. $C f$. Red Lion Broad- 
Thus, the rights of private actors to take lawful commercial initiatives and of the public to enjoy the benefits of an unrestricted market must be accommodated with professionals' right to assert professional values. Underlying both the rule of per se illegality for naked restraints of trade and the reasonableness requirement applicable to other actions taken by competitors in concert is a concern to identify and prevent hazards that, although perhaps not such "clear and present dangers" as would justify restraints on political speech, are nonetheless real and significant. ${ }^{227}$ While professionals should certainly be allowed to meet together as other groups are, they are no freer to engage in speech conducive to concerted action that subverts the public interest in competition and the "freedom of traders." 228 In an early trade association case, the Supreme Court found unlawful an exchange of information and opinion where such information and opinion was employed to knit a multitude of competitors into a conspiracy. ${ }^{229}$ The somewhat compara-

casting Co. v. FCC, 395 U.S. 367 (1969) (declaring that first amendment values permit regulation of broadcasters that improves the flow of information and weakens monopoly in the "marketplace of ideas"). In the circumstances under discussion here, consumers' interests are not obviously served by intraprofessional communications concerning competitive developments. Indeed, the argument is that not only are consumers' economic interests disserved but the medical profession's ideological monopoly is perpetuated. See note 214 supra.

227. The Supreme Court's recognition of the "sham exception" to the Noerr-Pennington doctrine, see text accompanying note 224 supra, indicates a willingness to recognize an anticompetitive hazard even where political speech is ostensibly involved. Where the "political" aspect-the invocation of or appeal to governmental processes - is missing or remote and the likelihood of a commercial purpose is strong due to the professionals' conflict of interests on the issues being discussed, a straight balancing test of the sort familiar in antitrust analysis would seem appropriate. See P. AREEDA, supra note 128, at 269-75, 409-10. In general, the "clear and present danger" test has not prevented a great deal of regulation affecting speech in substantial ways. See, e.g., Grayned v. City of Rockford, 408 U.S. 104, 116 (1972) (demonstration near school); United States v. O'Brien, 391 U.S. 367 (1968) (draft card burning); Adderly v. Florida, 385 U.S. 39 (1966); Giboney v. Empire Storage \& Ice Co., 336 U.S. 490, 502 (1949) (labor picketing). Compare United States v. Container Corp., 393 U.S. 333 (1969) (antitrust prohibition on exchange of price information) with Debs v. United States, 249 U.S. 211, 215-16 (1919) (focusing on the "material and intended effect" and the "probable effect" of the speech at issue). See also National Soc'y of Professional Eng'rs v. United States, 98 S. Ct. 1355 (1978) (upholding an injunction barring professional speech). Although a civil liberties lawyer approaching the problem without a sense of antitrust's own libertarian premise might reach a different conclusion, the development of a per se antitrust rule operating as a prior restraint on certain professional speech in certain contexts, see text accompanying notes 264-73 infra, should be quite defensible.

For the argument that concern about "chilling effects" and prior restraints may not be warranted with respect to purely commercial speech, see Virginia State Bd. of Pharmacy v. Virginia Citizens Consumer Council, Inc., 425 U.S. 748, 771 n.24 (1976).

228. Indeed, concerns about the ideological domination of health services delivery by physicians, see note 214 supra, and about the medical profession's solidarity in defending its interests, see notes 195-96 supra \& 271 infra, suggest that professional groups should be closely circumscribed in their communications in order to vindicate the freedom of vonsumers and their interest in innovation.

229. American Column \& Lumber Co. v. United States, 257 U.S. 377 (1921). This case drew 
ble activities of professional organizations should be subject to similar scrutiny, and, if a profession's propensity for concerted action appears particularly great, a commensurately strict limitation on intraprofessional communications would be justified.

The overriding object of the antitrust law's confrontation with the medical profession on these matters should be to change professional organizations from virtual arbiters of the features of the private financing and delivery system into mere advocates whose point of view must compete with others in the economic marketplace, the marketplace of ideas, and the political process. In response to this suggestion, many physicians will understandably decry the potential abuses they see in freer private-sector developments, and reduction of their powers could indeed facilitate some truly objectionable practices that might have been prevented. Nevertheless, medical organizations "are not law enforcement agencies," 230 except perhaps in some narrowly defined areas of professional self-government, nor are they suitable spokesmen for consumer interests on medical care issues having an economic aspect. Moreover, other protections against possible third-party abuses are available and probably adequate. For these reasons, organized medicine should be confined to the use of persuasion directed either toward consumers or toward political bodies. ${ }^{231}$

Although doctors' use of their power over private actors to dictate their economic environment must be curbed, medical groups certainly must be left free to pursue their legitimate political rights. Thus, a medical society should be free to protest a Medicare or other governmental policy that it finds objectionable, even to the extent of prompting many doctors to refuse to accept Medicare patients or to participate in another government health program. ${ }^{232}$ Indeed, it is not at all clear that

sharply the issue of free speech versus the Sherman Act's prohibition of vonspiracy. Justice Holmes, dissenting, said that he "should have supposed that the Sherman Act did not set itself against knowledge" and that the "decree as it stands seems to me surprising in a country of free speech that affects to regard education and knowledge as desirable." Id. at 412-13. Justice Brandeis, also in dissent, said, "[T]here is nothing in the Sherman Law which should limit freedom of discussion, even among traders." Id. at 416. Despite the illustriousness of the dissenters, the majority opinion has stood the test of time. See, e.g., United States v. Container Corp., 393 U.S. 333 (1969).

230. American Medical Ass'n v. United States, 130 F.2d 233, 249 (D.C. Cir. 1942), aff'd, 317 U.S. 519 (1943).

231. In particular, the emerging health systems agencies (HSAs) would seem to provide an appropriate local forum for medical organizations to advocate their views without simultaneously stirring up the profession to vigilante action. See the National Health Planning and Resources Development Act of 1974, 42 U.S.C. $\$ \$ 300 \mathrm{k}-300 \mathrm{t}$ (Supp. V 1975). The HSAs would seem clearly to perform a quasi-governmental function entitling competitor groups to Noerr-Pennington protection in advocating their interests.

232. See, e.g., MDs Fight New York Fee Policy, Am. Med. News, Jan. 16, 1978, at 1, col. 1 
the antitrust laws would prohibit an organized doctors' strike to obtain a change in, say, the state Medicaid program; although the injury to innocent parties-the Medicaid beneficiaries-would sorely tempt the courts to find a remedy, it would be improper to ignore a well-founded claim that the strike was political action undertaken to protect professionals from the exercise of government's monopsony power. ${ }^{233}$ However these issues are resolved, developments in private financing and delivery mechanisms are, by definition, neither political nor governmental, and the rigorous antitrust rules against private policing of private economic behavior would apply. Indeed, the fundamental legal distinction between concerted action taken against governmental policies and that directed at private actors is one reason why initiatives in the private sector may offer a significantly better opportunity than stronger government controls for ultimately breaking the medical profession's grip on the financing and delivery system.

3. The "Seal-of-Approval" Analogy. A medical organization's assertion of a right to approve or disapprove the structuring and administration of private third-party payment plans and other developments in the private financing and delivery of care may best be analyzed by drawing an analogy to "seal-of-approval" and other standard-setting programs. Such programs have been tolerated, within limits, by the antitrust authorities in many industrial settings ${ }^{234}$ because they are perceived as conveying information useful to consumers and others. This advantage is deemed to outweigh the hazard of anticompe-

(reporting professional reaction to a fee schedule for services under the state workmen's compensation program).

233. For the view that such boycotts are illegal and a review of the litigation (so far inconclusive), see Weller, Medicaid Boycotts and Other Maladies from Medical Monopolists: An Introduction to Antitrust Litigation and the Health Care Industry, 11 CLEARINGHOUSE REv. 99, 102-04 (1977). See also DeGregorio v. Segal, 443 F. Supp. 1257 (E.D. Pa. 1978) (not raising the NoerrPennington defense). A question exists whether boycotts directed at government policy, particularly an exploitative one, see notes 132-33 supra, would have a stronger claim to constitutional protection than "political" boycotts aimed at private parties. For a discussion of the limits of legal control on the latter type of coercive behavior, see Note, supra note 220 . Although George $R$. Whitten, Jr., Inc. v. Paddock Pool Builders, Inc., 424 F.2d 25 (1st Cir. 1970), suggests that the Noerr defense is not available to shield dealings with government as a purchaser of goods and services, see also Fischel, supra note 220 , at $115-18$, that case did not involve a true political issue such as a complaint that government was exerting its monopsony power unfairly. While a conspir* acy to rig competitive bids would be clearly unlawful, when government proceeds by fiat or fee schedule it can be said to have set the private market aside and arguably to have a constitutional duty to permit collective bargaining. Whether or not the state could pass a law expressly prohibiting boycotts in such circumstances, the antitrust laws should not apply to such a political dispute.

234. See, e.g., Structural Laminates, Inc. v. Douglas Fir Plywood Ass'n, 261 F. Supp. 154 (D. Ore. 1966), affd per curiam, 399 F.2d 155 (9th Cir. 1968), cert. denied, 393 U.S. 1024 (1969); Roofire Alarm Co. v. Royal Indem. Co., 202 F. Supp. 166 (E.D. Tenn. 1962), affd, 313 F.2d 635 (6th Cir.), cert. denied, 373 U.S. 949 (1963). 
titive abuse sufficiently to warrant taking the trouble to evaluate the program's reasonableness in each case. Many legitimate self-regulatory programs in the health care system involve granting the equivalent of a seal of approval showing that certain standards have been met.

The typical industrial "seal-of-approval" program does not present the hazard of stimulating a true boycott by members of the accrediting association, because such members are usually not customers or suppliers of applicants for approval (or in a position to prescribe their products or services). Although frequently the accrediting body is comprised of competitors of the applicant, this circumstance is tolerated because, although an anticompetitive animus is possible, the decision to honor the seal is made by others, who can judge for themselves what it is worth. In one case, certain utilities allegedly refused to supply natural gas for use in a burner unapproved by an association of which they, together with other appliance manufacturers, were members. ${ }^{235} \mathrm{Al}-$ though an actual conspiracy to boycott was not clearly alleged in the complaint, the Supreme Court reacted to the boycott hazard that it perceived and held that a Sherman Act violation had been pleaded even though a utility might have had good reasons of its own for unilaterally honoring the seal-of-approval program. The case indicates that the Court is acutely alert to the risk of anticompetitive abuse wherever a boycott may be employed as a sanction, even in the name of product safety. Thus, the inherent danger that physicians in significant numbers would honor a professional "seal of approval" and penalize its absence should expose professional evaluations of innovative financing and delivery arrangements to the closest antitrust scrutiny. ${ }^{236}$

Though administering a "seal-of-approval" program in an open and seemingly reasonable way, a medical society could easily set conditions for approval that, while ostensibly ensuring ethics, the quality of

235. Radiant Burners, Inc. v. Peoples Gas, Light \& Coke Co., 364 U.S. 656 (1961) (per curiam). This case is sometimes misinterpreted as treating the defendants' refusal to grant the seal of approval as a boycott condemned under the per se rule. See, e.g., L. Sullivan, supra note 212, at 243. In fact, the alleged conspiratorial refusal "to provide gas for use in the plaintiff's Radiant Burners" was clearly the offense found. 364 U.S. at 660 . In another case sometimes incorrectly regarded as involving a boycott, an educational accreditation program was upheld despite somewhat arbitrary practices. Marjorie Webster Jr. College, Inc. v. Middle States Ass'n of Colleges \& Secondary Schools, Inc., 432 F.2d 650 (D.C. Cir.), rev'g 302 F. Supp. 459 (D.D.C. 1969), cert. denied, 400 U.S. 965 (1970). But the evidence established that the schools constituting the accrediting organization freely adopted their own policies toward graduates of the unaccredited school, accepting many transfer students. $302 \mathrm{~F}$. Supp. at 468.

236. For a case involving a true boycott, the equivalent of a seal of approval, and the medical profession, see Community Blood Bank of Kansas City Area, Inc., 70 F.T.C. 728 (1960), rev'd on other grounds, 405 F.2d 1011 (8th Cir. 1969), discussed in notes 210-11, 214 supra and text accompanying notes 208-11, 214 supra. 
care and the doctor-patient relationship, primarily serve to protect the profession's economic interests and to frustrate cost-containment efforts. Indeed, the AMA appears to have achieved its objectives in the past by just such methods-for instance, by promulgating standards for ethical prepayment plans. ${ }^{237}$ Of course, there would be no substantial problem if it were possible to arrange that the society's views were conveyed only to consumers, who could make up their own minds, or were given only limited publicity in the professional community. But, once the word is given to the profession as a whole, many members might take it as a signal to cooperate only with approved plans or providers, with possibly decisive effects on the prospects for innovation. ${ }^{238}$

The social utility of "seal-of-approval" mechanisms is greatest in areas of particular technical complexity where consumers require special assistance and protection. It is not at all clear that third-party costcontainment initiatives present issues requiring scientific or technical expertise or that consumers and individual providers cannot protect themselves adequately against third-party abuses and make competent decisions without medical society assistance. The tenuousness of a medical organization's claim to a role in approving financing arrangements is revealed by a comparison with certification of specialists by medical specialty boards and with other self-disciplinary activities of the profession. ${ }^{239}$ Some discussion of these self-disciplinary activities will be helpful in putting the coercive boycott in its true light and in showing how the antitrust laws may be used to curb abuses of the profession's power over its own members without sacrifice of the potentially substantial benefits of self-regulation.

\section{Professional Self-Discipline.}

1. Applying the Rule of Reason. The self-disciplinary powers exercised by the medical profession over its own members present significant antitrust issues, but the particular mechanisms employed-medical society memberships, hospital staff privileges, specialty certification, educational accreditation ${ }^{240}$ and other "seal-of-ap-

237. See text accompanying notes 47-48 supra.

238. The concern is that, as in the Oregon State Medical Society case, see text accompanying notes 42-57 supra, the profession could use any power to approve or disapprove financing plans and their practices to select a "chosen instrument" behind which to rally in resisting innovation. See text accompanying notes 279-98 infra.

239. See text accompanying notes 251-52 infra.

240. The FTC has challenged the role of the AMA in the Liaison Committee on Medical Education (LCME) in an administrative proceeding in the U.S. Office of Education. See Ruhe, Recent Events of Special Interest to Medical Education, 238 J.A.M.A. 2761, 2763 (1977). One statement submitted in that proceeding argued that the issue was 
proval" programs-do not normally involve true boycotts and therefore require more extensive evaluation. Under the standard "ruleof-reason" analysis, these self-regulatory mechanisms are to be judged in terms of their possible benefits, their possible harms and the likelihood of each, with attention as well to the usefulness of attempting to establish the preponderance of benefit or harm in each case through litigation. ${ }^{241}$ By the same token, consideration should be given to the possible value of a clear rule as a guide to professional conduct. Even if the rule were somewhat arbitrary, it might be preferable to a rule whose flexibility could easily be taken advantage of by professionals invoking plausible quality arguments, professional values or subjective judgments against physicians whose real offense was advertising, price cutting or cooperating with innovative providers or financing plans. Finally, a legal assessment should encompass the possibility of striking the right balance by assigning the burden of proof to one side or the other in such a way as to accommodate the traditional functions of professional groups with antitrust policy's sometimes powerful distrust of concerted action by competitors. ${ }^{242}$ Thus, discipline of a competitor

\footnotetext{
the openness and responsiveness of the educational process itself, in particular its freedom from or domination by a professional orthodoxy which may not be wholly congruent with the public's needs. ... .

The power to define how a doctor is educated is the power to define what a doctor is, and this is more than a straightforward, technical undertaking which can be safely entrusted to organized professional interests. We attempt to demonstrate in this statement the existence of a substantial danger that the LCME, by reason of its control by organized medicine and the medical education establishment, imposes on medical education a particular professional ideology, deeply rooted in a particular perception of the physician's role in society and antagonistic to educational endeavors premised on different perceptions.
}

Letter to Dr. Ernest L. Boyer, U.S. Commissioner of Education (Designate), from Clark C. Havighurst and Gaylord Cummins 2-3 (Mar. 9, 1977) (copy on file with Duke Law Journal). Issues also exist with respect to the AMA's role in accrediting allied health education programs. See Ruhe, supra, at 2764.

241. It is important to recognize that application of the rule of reason to a particular practice may result in the establishment of a new category of per se offenses as soon as the courts have accumulated experience enough to establish a conclusive presumption of unreasonableness. See, e.g., White Motor Co. v. United States, 371 U.S. 253, 261-64 (1963). Because the courts are just embarking on the task of applying antitrust principles to professional conduct, per se rules may well emerge. This could occur either by refusing to distinguish certain professional conduct from analogous conduct in industrial settings, see National Soc'y of Professional Eng'rs v. United States, 98 S. Ct. 1355 (1978); Goldfarb v. Virginia State Bar, 421 U.S. 773 (1975), or by framing special rules for professional self-regulatory activities. See, e.g., Silver v. New York Stock Exch., 373 U.S. 341 (1963). Among the factors affecting the outcome under the needed rule of reason inquiry will be the courts' awareness of the limitations of judicial processes in identifying underlying purposes and actual economic effects in particular circumstances. See Northern Pac. Ry. v. United States, 356 U.S. 1, 5 (1958). Where a per se rule is not applied, a rule of reason inquiry still does not permit justification of a naked restraint on competition by showing some ostensible worthy purpose. National Soc'y of Professional Eng'rs v. United States, 98 S. Ct. 1355, 1363-65 (1978).

242. See generally Note, A Suggested Role for Rebuttable Presumptions in Antitrust Restraint of Trade Litigation, 1972 DUKE L.J. 595. 
by his peers might sometimes be permitted only on the condition that the professional organization is prepared, under the reasonableness requirement, to justify -in terms of their validity, objectivity and benefit/cost ratios-the quality or other standards being implemented and to demonstrate the fairness and evenhandedness of their enforcement.

Professional self-discipline is directed at physicians themselves and not at third parties. As the court of appeals stated in the $A M A$ case, medical associations are
permitted to organize, to establish standards of professional conduct, to effect agreements for self-discipline and control. There is a very real difference [,however,] between the use of such self-disciplines and an effort upon the part of such associations to destroy competing professional or business groups or organizations. ${ }^{243}$

This language, simply reflecting the court's recognition that it was Group Health rather than individual doctors that was the real target of the restraints in that case, does not imply that professional groups have a free hand in policing their own members. Although the $A M A$ case is sometimes interpreted as curbing the medical profession's self-disciplinary powers only where the brunt of the restraint is borne by someone or some entity other than an individual professional, ${ }^{244}$ antitrust concerns would also arise where restraints were directed at professionals engaged in aggressive fee-for-service competition-by advertising or fee-cutting, for example. Nevertheless, the ratio of benefit to risk is probably greater where there are no third-party effects, and the law's stance should reflect this probability. This could be done by requiring an aggrieved professional to prove the unreasonableness of the selfregulatory scheme as applied to him unless he could show either an anticompetitive pattern or a third-party effect, in which case the professional group would then have the burden of justifying the restraint. But strictly intraprofessional restraints must not be passed over lightly, for, as the Goldfarb case recognized, the consumer has a stake in competition among professionals themselves ${ }^{245}$ as well as in the fate of competitors of other kinds. Indeed, to limit the role of the antitrust laws to policing only restraints on substitutes for doctors' services or for feefor-service medicine, such as Group Health, would be to endorse continued monopolization of these relevant markets.

The courts have still before them the considerable task of reconciling antitrust principles with the recognized self-regulatory responsi-

243. 130 F.2d at 248 (emphasis in original).

244. See, e.g., Goldfarb v. Virginia State Bar, 497 F.2d 1, 14-15 nn. 36 \& 42 (4th Cir. 1974), rev'd, 421 U.S. 773 (1975).

245. See 421 U.S. at 786-88. 
bilities of the organized professions. To guide them, the antitrust enforcement agencies and the courts have their earlier experience in using antitrust policy to structure and direct industrial self-regulatory activities so as to curtail the potential for abuse while retaining the public benefits which flow from such activities. Perhaps the leading case is Silver v. New York Stock Exchange, ${ }^{246}$ in which the Supreme Court used antitrust principles to impose upon the stock exchange an obligation to employ certain procedural safeguards to minimize the risk that its self-regulatory powers would be used to injure competitors of exchange members. It would be surprising if the implied self-regulatory prerogatives of professional organizations were any broader than the statutory powers exercised by the New York Stock Exchange or were entitled to any greater deference in an antitrust court. Moreover, the apparent ability of professional groups to impose informal sanctions-boycotts as well as social and other pressures-argues strongly for insisting on adherence to reasonable procedural standards as a prerequisite to any concerted action threatening to competition. A duty to investigate, to inform the subject of any complaint and to deal with issues openly, rather than covertly through a whispering campaign or an "old boy network," would seem an important protection of competitive values. ${ }^{247}$

2. Antitrust's Impact on Specific Mechanisms of SelfDiscipline. To clarify how legitimate self-regulatory activities may proceed in the face of antitrust's vigilance against restraints on innovation, it is useful to review quickly the various mechanisms of professional self-discipline. This survey is intended only to identify the problems, if any, presented under the foregoing principles.

Denial of membership in, or expulsion from, a medical society is not a boycott in and of itself, but it has sometimes been used as a signal for society members to cease dealing with the practitioner involved. ${ }^{248}$ Moreover, if the ground of exclusion is cooperation with a disapproved plan or provider, it is conclusive evidence of the society members' conspiracy to boycott that plan or provider. ${ }^{249}$ Similarly, the medical soci-

246. 373 U.S. 341 (1963).

247. See the discussion of Feminist Women's Health Center in note 221 supra. Another case in which professional action allegedly taken for noncommercial reasons was so informal as to deprive the object of the boycott of any means of self defense is Community Blood Bank, Inc., 70 F.T.C. 728 (1966), rev'd on other grounds, 405 F.2d 1011 (8th Cir. 1969), discussed in notes 210-11, 214 supro and text accompanying notes 208-11, 214 supra.

248. See text accompanying notes 9-16 supra.

249. Deprivation of the benefits of society membership is an excellent sanction to induce action in the common interest. See note 271 infra. 
ety should not be permitted to take steps to cause others to use medical society membership as a prerequisite for some privilege, such as admission to a hospital staff. Where significant privileges are in fact attached to society membership, both common law and antitrust principles ${ }^{250}$ would enforce requirements of procedural and substantive fairness. It should not be difficult to administer such rules so that membership policies would present no difficulties where there had not in fact been an abuse.

Specialty certification likewise should not be significantly impaired by closer antitrust scrutiny. This "seal-of-approval" mechanism supplies useful and otherwise unavailable information to consumers and others and, in view of this substantial public benefit, would be granted considerable freedom under antitrust principles and subjected to no unfavorable presumption. Nevertheless, specialty boards may not sponsor boycotts ${ }^{251}$ and will be obligated to deal fairly with their members and aspirants for certification or membership. ${ }^{252}$ Though the burden of proof as to the reasonableness of standards and procedures would ordinarily fall on one challenging them, the well-advised specialty society would be prepared to defend its policies and their application. Attempted interference with innovative plans or providers would of course trigger an antitrust response.

Denial or withdrawal of hospital staff privileges does not involve a technical boycott but only the hospital's unilateral refusal to deal. ${ }^{253}$ However, because staff privileges are administered primarily by physicians who are competitors of the applicant, antitrust principles apply, and their application must reflect recognition that this substantial power is probably more hazardous to competition and innovation than any other entrusted to the medical profession. Under the doctrine of Associated Press v. United States, ${ }^{254}$ control by one group of competitors of a resource vital to other competitors invites close antitrust scrutiny. ${ }^{255}$

250. See notes 13-14, 247 supra and text accompanying notes 13-15, 246-47 supra. See also text accompanying note 254 infra.

251. United States Dental Inst. v. American Ass'n of Orthodontists, 396 F. Supp. 565, 580- 81 (N.D. Ill. 1975); Veizaga v. National Bd. for Respiratory Therapy, 1977-1 Trade Cases \ 61,274 (N.D. Ill. 1977).

252. This obligation arises under antitrust law and common law principles. See Pinsker v. Pacific Coast Soc'y of Orthodontists, 12 Cal. 3d 541, 552, 526 P.2d 253, 261 (1974). See text accompanying notes 246-47 supra.

253. See note 24 supra and accompanying text.

254. 326 U.S. 1 (1945).

255. See id; United States v. Terminal R.R. Ass'n, 224 U.S. 383 (1912); Gamco, Inc. v. Providence Fruit \& Produce Bldg., Inc., 194 F.2d 484 (1st Cir.), cert. denied, 344 U.S. 817 (1952); Dalmo Sales Co. v. Tysons Corner Regional Shopping Center, 308 F. Supp. 988 (D.D.C.), aff d, 
Staff privilege disputes are, of course, legion, and most do not raise true antitrust issues. Although more such cases are being heard in the federal courts after the Rex Hospital case, ${ }^{256}$ cases involving no more than an allegation of anticompetitive action toward a single physician should probably be dismissed on jurisdictional grounds for inadequate impact on interstate commerce. ${ }^{257}$ This would leave before the antitrust courts all staff-privilege cases involving either a pattern of anticompetitive conduct or an attempt to injure a third-party competitor or the initiator of unpopular cost-containment measures. Under some such delineation of the federal court's role, the antitrust laws would be in a position to exert some influence over hospital staffs in those areas where innovation is most in jeopardy. The problem of reconciling the recognized self-regulatory responsibilities of the hospital staff with antitrust concerns would then have to be faced.

In line with the Silver case, as well as emerging constitutional and common law principles, ${ }^{258}$ certain procedural obligations can be imposed on hospital staffs and, presumably, on other legitimate self-regulatory bodies such as PSROs. Among the principles of procedural due process that might appropriately be carried over from constitutional to antitrust law governing hospital staffs is protection against conflicts of interest on the part of those exercising self-regulatory powers. In the 1973 case of Gibson v. Berryhill, ${ }^{259}$ the Supreme Court found a violation of due process in a state regulatory scheme that empowered feefor-service optometrists to discipline salaried optometrists in such a way as to threaten their corporate employers' survival as competitors of the private practitioners. ${ }^{260}$ The antitrust laws provide a particular warrant for stressing the importance of such conflicts of interests and for insisting that they be minimized in any self-regulatory scheme. ${ }^{261}$ In the hospital setting, issues should be resolved by staff committees (or even outside consultants) not immediately interested in the outcome,

429 F.2d 206 (D.C. Cir. 1970). The actual availability of another hospital might be a defense, but where a physician has been excluded from all of the hospitals in the community it should not be necessary for him to prove a broader conspiracy.

256. See text accompanying note 173 supra.

257. But see Zamiri v. William Beaumont Hosp., 430 F. Supp. 875 (E.D. Mich. 1977) (jurisdiction upheld solely on the basis of flow of Medicare payments to the defendant hospital).

258. See notes $21,24-25$ supra and text accompanying notes 21-25 supra.

259. 411 U.S. 564 (1973).

260. The Court found that the state licensing board was so dominated by fee-for-service optometrists that no salaried practitioner could get a fair hearing. Id at 578-79. Cf. Sams v. Ohio Valley General Hosp. Ass'n, 413 F.2d 826 (4th Cir. 1969) (denial of equal protection to HMOaffiliated physicians).

261. See Blalock v. Ladies Professional Golf Ass'n, 359 F. Supp. 1260, 1265 (N.D. Ga. 1973). See also note 214 supra and accompanying text. 
and the hospital board's involvement should be more than perfunctory. ${ }^{262}$

From the foregoing survey of legal doctrines as adapted to the field of professional self-regulation, it appears that the medical profession's legitimate disciplinary activities may proceed without antitrust jeopardy. ${ }^{263}$ On the other hand, legal doctrine can be attuned to pick up anticompetitive signals and adjust the analytical framework so as to eliminate special deference to professionalism where necessary to respond to a danger of abuse. Where third parties such as HMOs, health insurers, union- or employer-sponsored health plans, or innovative delivery organizations are affected, antitrust doctrine can be mobilized to protect them-not for their own sake but as vehicles of change in the public's interest.

\section{The Efficacy of Antitrust for Combatting Subtle Restraints.}

Much emphasis has been placed in this Article on the medical profession's surprising ability to control its economic environment by virtue of its solidarity on issues of commercial self-interest and its tight control over the resources that would-be innovators require. But to recognize the perniciousness of a local medical community's ability to orchestrate effective professional resistance to private cost containment and other initiatives is only to identify the problem, not to solve it. It is manifestly impossible to prevent altogether, or even to deny the legitimacy of, practitioners' interchange concerning business developments affecting them. Moreover, intraprofessional communications frequently occur in code, with commonly accepted "buzz words" triggering the desired responses but defying the easy application of legal sanctions. Further, informal professional pressures which can be used to govern

262. In particular, consumer members of the hospital board should be careful to scrutinize staff decisions. Of course, the hospitals themselves are subject to a conflict of interests in some instances, such as where an HMO threatens to utilize the hospital less intensively than fee-forservice physicians. Conspiracies among hospitals would be equally subject to antitrust restraint.

263. In the Silver case, the Supreme Court recognized the possibility that an overhanging threat of antitrust liability might discourage aggressive self-regulation but stated that "under the aegis of the rule of reason, traditional antitrust concepts are flexible enough to permit the Exchange sufficient breathing space within which to carry out the mandate of the Securities and Exchange Act." 373 U.S. at 360 (emphasis added). It also suggested that liability would attach only "for anti-competitive acts of self-regulation which fall too far outside the scope of the Exchange Act." Id. at 362 (emphasis added). It declined, however, to declare whether "a particular enforcement of the rules on its merits is to be governed by a standard of arbitrariness, good faith, reasonableness, or some other measure." $I d$. at 366 . In requiring the observance of procedural protections, the Court said that it had "provided not a brake upon the private partner executing the public policy of self-regulation but a balance wheel to insure that it can perform this necessary activity in a setting compatible with the objectives of both the antitrust laws and the Securities Exchange Act." Id. at 367. 
individual practitioners' behavior cannot be easily identified or measured, and any attempt to reconstruct in an antitrust case how a competitive threat was perceived and dealt with in a medical community is bound to be a major undertaking. Though today discovery proceedings would frequently reveal a "smoking gun," increased sophistication on the part of the profession could soon result either in nonpreservation of evidence or in such linguistic smoke-screens as ethical discourse, appeals to individual conscience, or ostensible mobilization for political action. Some attention must be given to the problem of devising a remedy imposing on professional associations a requirement of neutrality toward cost-containment measures taken by private third parties.

1. Clarifying the Law. Even if effective enforcement of antitrust principles in professional contexts would be difficult, one should not discount too much the value of a prompt clarification of medical organizations' responsibilities under the antitrust laws. At the present time, physicians operate without recognition of their legal obligations. Though long accustomed to acting as a law unto themselves, they might change their behavior in material ways if educated to the reasons why the law demands that they respect the freedom of others to innovate in the interest of consumers and that they accord consumers and individual physicians the right to make the ultimate choices. If appeals to physicians' sense of justice and social responsibility are unavailing, clarifying the threat of antitrust sanctions may still accomplish the desired result. Physicians' self-interest might also respond to the argument that permitting the market to become more competitive can forestall moves to install the government as the chief decisionmaker or sole purchaser of medical services. Moreover, would-be innovators might be substantially encouraged in their efforts by a clarification of legal principles and by an indication that the antitrust enforcers and the courts would run interference for them against the doctors.

In order to achieve the desired clarification of the law without drawn out proceedings and the uncertainty attending case-by-case development, the FTC might consider the possibility of initiating a rulemaking proceeding to clarify in a "trade regulation rule" what is and what is not permissible in the way of medical organizations' responses to private cost-containment initiatives. ${ }^{264}$ Though it is premature to propose finally the content of such a rule, it might go so far as to prohibit voluntary associations of competing physicians ${ }^{265}$ from officially

264. See 15 U.S.C. \$ 46(g) (1976); National Petroleum Refiners Ass'n v. FTC, 482 F.2d 672, 698 (D.C. Cir.), cert. denied, 415 U.S. 951 (1974).

265. The FTC's jurisdiction over nonprofit associations, such as medical societies, is unfor- 
expressing (by way of resolution, official statement, editorial or otherwise) either approval or disapproval of a particular third-party initiative or of a general method of cost containment. ${ }^{266}$ The rule would have to specify a number of things with particularity and might include some examples, perhaps drawn from the FTC's investigations, of the kinds of things prohibited or regarded as permissible. One advantage of using the rule-making approach here would be that it would involve accusing no one directly of wrongdoing but would simply enunciate a clear rule to govern future conduct. ${ }^{267}$ There would seem to be no less painful way to effectuate the revolution in the status and governance of the professions that is implicit in the Goldfarb case.

Simply declaring that the medical society must remain neutral on private cost-containment ventures initiated without its advice would most likely not be sufficient to create an environment conducive to effective private initiatives. It would probably be necessary to prohibit as well the approval (or disapproval) or endorsement even of programs that were voluntarily brought to the society by their proponents. Otherwise, a de facto "seal-of-approval" scheme would emerge, with the possible result that all plans lacking the society's imprimatur would be discriminated against by physicians acting in part in defense of the profession's collective welfare. The experience revealed in the record of the Oregon State Medical Society case demonstrates that, if the profession is allowed a chosen instrument as a financing vehicle, it is in a strong position to set rules for all insurers without explicitly calling for a boycott. ${ }^{268}$ Because application of the antitrust "rule of reason" in such situations allows a balancing of expected public benefits against expected harms, there is ample authority for the courts (or for the FTC in developing a trade regulation rule) to assess the probabilities and conclude that the public interest requires the more extensive prohibition.

tunately in some doubt. See Community Blood Bank v. FTC, 405 F.2d 1011 (8th Cir. 1969). The FTC has not been deterred, however, and has undertaken to prove that the AMA is operated for the "profit . . . of its members," as required by $\S 4$ of the FTC Act, 15 U.S.C. $\$ 44$ (1976). American Medical Ass'n, F.T.C. Dkt. No. 9064, TRADE REg. REP. (CCH) ๆ 21, 302 (Apr. 26, 1977). The conflict-of-interests analysis in the text accompanying note 214 supra might help the Commission overcome this obstacle, permitting jurisdiction to be asserted on an objective rather than a subjective basis. See note 224 supra. Indeed, the suggested rule might take the form of a specification of activities triggering the Commission's jurisdiction.

266. The "free speech" arguments against such a radical remedy are evaluated in the text accompanying notes 220-23 supra.

267. By proceeding under the FTC Act rather than the Sherman Act, the FTC would avoid exposing physicians to criminal and treble damage liability.

268. See Goldberg \& Greenberg 58-62. See also text accompanying notes 279-98 infra, arguing that financing and cost-containment measures dominated by organized medicine should be prohibited under antitrust principles for the same reasons. 
In developing rules for medical societies, particular problems could be anticipated in the presentation of "news" to the members through society-sponsored publications. Consideration should perhaps be given to prohibiting society-sponsored publicity tending to induce a boycott, such as reporting of explicit proposals for boycotts or of inflammatory opinion unbalanced by opposing views. Although it is not obvious just how a rule could effectively prevent a medical society from allowing its meetings to become forums for conspiracy-making, the enforcement agencies and the antitrust courts have had experience with trade association meetings in other industries ${ }^{269}$ and should be able to define potential abuses. Total repression of discussion would not be appropriate, of course, ${ }^{270}$ and is not required. All that is needed is an effective impairment of physician organizations' ability to inspire a critical mass of physicians to act with primary regard for their collective rather than their individual self-interest. ${ }^{271}$ Finally, it is elementary that the medical society should avoid actions designed to penalize individual physicians who elect to cooperate with cost-containment efforts, including identification of such individuals by name so as to invite their colleagues to exert pressure upon them.

Such restrictions on a medical society, its officers and its newsletter, if they should be adopted, would undoubtedly be perceived as extreme measures, but anything less might be inadequate to break the organized profession's de facto grip on developments not legitimately subject to its control. It is arguable, of course, that such a remedy is more appropriately imposed as a remedial measure following a finding of a specific violation than in a trade regulation rule designed to clarify

269. See, e.g., American Column \& Lumber Co. v. United States, 257 U.S. 377 (1921).

270. See text accompanying notes 220-33 supra.

271. The logic of collective action requires that each individual actor have some assurance of solidarity within the group. Without such assurance, an individual would perceive no benefit to himself in acting against his immediate self-interest. See M. Olson, THE LoGic OF Collectrve ACTION 9-16 (1971). Professional organizations are able to minimize the "free-rider" problem-the tendency of individuals to let others bear the cost of taking action that would benefit the entire group-in a variety of ways: First, membership in the organization itself may carry certain benefits unrelated to the benefits of parallel behavior, making loss or denial of membership a sanction to be feared. Id. 137-41. See text accompanying notes 12-25 supra on the use of medical society membership and hospital staff privileges to achieve professional solidarity. Second, explicit regulatory powers possessed by the organization will typically feature a degree of prosecutorial discretion, making a professional naturally fearful of violating the revealed preferences of his colleagues. See text accompanying notes 24-25 supra. Third, informal interaction also provides a means of registering disapproval of independent behavior. Finally, ideological cohesiveness, reflecting the nonmonetary returns from and features of professional practice, may also serve to strengthen the commitment to parallel action. Many of the mechanisms for encouraging interdependent behavior will work best in smaller groups. See M. OLsoN, supra, at 22-36, suggesting that serious antitrust problems are most likely to be found in local medical organizations and hospital staffs. 
the substantive offense. ${ }^{272}$ Nevertheless, if investigation confirmed the existence of a real hazard of boycott and harassment due to the medical profession's receptivity to signals flashed in code from society headquarters, the mere sending of such signals could be barred as creating such a danger to the public, and carrying so little public benefit, that it could be classed as a restraint of trade or, under the Federal Trade Commission Act, as an "unfair method of competition."273

The dependence of physicians on hospital staff privileges and on the good will of their hospital colleagues creates an enormous problem for antitrust enforcement, because interactions among staff members are close, presumptively legitimate, and difficult to reconstruct or evaluate after the fact. But, even though it will be impossible to prevent many subtle pressures from being exerted, clarification of antitrust doctrine applicable to hospital medical staffs should still be useful in curbing the worst abuses and thereby improving the prospects for innovation. Perhaps an FTC trade regulation rule delineating the legitimate scope of hospital staff activities would be of value. Among the things that might be excluded by rule from the staff's agenda, except where specifically relevant to legitimate staff activities, are such matters as competitive developments in the community and the cost-containment initiatives of private third-party payers. Where the staff as an entity does have a legitimate concern with some third party's activities, it might be required to adhere to appropriate procedures. Even if such explicit restrictions on hospital staff discussions seem too extreme or difficult to enforce fairly, the alternative might be even worse from the medical profession's point of view-either a continuation under uncertain legal rules of harassing lawsuits destructive of effective and desirable peer review or a de facto or de jure shift to open staffs.

While clarifying the law should yield significant benefits, it is not clear that prospective case-by-case remedies could add much to what has been suggested here. An injunction issued following a finding of a violation might not be much more specific or clear than an FTC rule or recognized legal doctrine, and the effort required to obtain such an or-

272. The judgment in National Soc'y of Professional Eng'rs v. United States, 98 S. Ct. 1355 (1978), prohibited the Society "from adopting any official opinion, policy statement or guideline stating or implying that competitive bidding is unethical." Id. at 1368. The Court, with Chief Justice Burger dissenting on the point, found no merit in the claim that this order abridged first amendment rights. The discussion focused on the remedial context, thus leaving open the possibility that preventive rulemaking would be regarded differently.

273. Although such a rule would act as a prior restraint on expression by organizations that had not themselves been shown to be predisposed to conspiracy-making, the inherently commercial aspect of such speech, given the strong economic interests of the professionals engaging in it, should relax the standard for determining whether it can be restrained. See note 226 supra. 
der against a single county medical society or a single hospital staff might seem seldom justified by the relief obtained. As a consequence, attention must be given to policing these peculiarly intractable restraints by the encouragement of treble damage suits and by criminal proceedings against flagrant abusers of professional power. Regrettable as it would be to impose such sanctions on an honorable profession, its education to society's new expectations may require it.

\section{Assessing the Prospects for Innovation Under an Antitrust} Regime. Even if antitrust principles are clarified and applied to give appropriate effect to concerns about how physicians' concerted action can inhibit innovations in health care financing and delivery, it is still far from certain that would-be innovators would have as free a hand as one might wish. Although conditions might be more conducive to private initiatives than they are at present, it would be naive to think that the job was complete. As has been seen, physicians have a considerable capacity to frustrate change at the local level and they could well succeed in many instances despite the best efforts of antitrust enforcers and the courts. Moreover, recognition of potential obstacles could deter all innovations except those acceptable to the profession, thus occasioning no overt behavior to which antitrust penalties could attach. Finally, even if an innovative plan were in fact the victim of egregiously predatory practices, it might be reluctant to sue, to threaten suit or to invoke the public prosecutor for fear of hardening the opposition still further, with only an uncertain prospect of ultimate relief. The better part of valor might be for the plan to accommodate itself to the profession's demands, dropping its more threatening features. The deal struck would be directly proportionate to the profession's de facto power, perhaps reduced, but not eliminated, by the antitrust threat.

When litigation did arise, there would be a substantial risk that the courts would hesitate to doubt professionals' motives, to narrow professional groups' claims to self-regulatory power, or to place on provider organizations the burden of proving the legitimacy of their goals and methods. Indeed, many judges, themselves members of a learned profession, will regard as undue cynicism the skepticism about physician organizations which antitrust enforcers bring to this endeavor. Heavy costs and long delays would result if the courts, taken in by professionals' expressed concern for the quality of care and other ostensibly noncommercial values, prove reluctant to use per se principles in dealing with professional activities.

For all these reasons, antitrust policing of informal concerted action in the medical profession may not, by itself, succeed in adequately 
protecting opportunities for change. There should, however, be no thought that an enforcement effort to curb professional restraints is not worth making. Instead, the implication to be drawn may be that something more is required. Thus, not only must private sector initiatives of all kinds receive increased governmental encouragement (or reduced discouragement), ${ }^{274}$ but antitrust enforcers must consider going beyond addressing professionally imposed restraints on would-be innovators and contemplate challenging some of the other foundations of the medical profession's power. ${ }^{275}$

\section{The Antitrust Status of the Profession's OWN "REFORMS"}

If antitrust enforcement concentrating on health care providers' coercive tactics cannot be counted on satisfactorily to open up opportunities for experimentation and change in the market for health care financing and delivery, what else can be done? The usual answer is that government regulation and purchasing power must be brought to bear, but the argument suggested here is that antitrust enforcement must focus not only on exclusionary practices such as boycotts and abuses of the medical profession's disciplinary powers but also on the profession's more sophisticated tactics in the struggle to shape health care financing and delivery in the doctors' interest.

Earlier discussion has shown how the medical profession's ability to retain its prerogatives has been greatly strengthened by its periodic moves to provide or make available on a limited basis what the public was coming to demand. Thus, Blue Shield plans were a limited answer to the demand for health insurance, ${ }^{276}$ limited acceptance to HMOs was a concession to a fait accompli, ${ }^{277}$ and foundations for medical care (FMCs) were a limited response to the desire for HMO-type care and

274. The present tax laws are a substantial disincentive to cost-containment innovation. See text accompanying notes 164-65 supra.

275. In addition to the enforcement agenda laid out in the next section of this Article, antitrust enforcers have been looking at a number of institutional bulwarks of professional dominance. The FTC has challenged the AMA's role in the accreditation of medical schools, see note 240 supra, and has challenged restrictions on professional advertising, see American Medical Ass'n, F.T.C. Dkt. No. 9064, TRADE REG. REP. (CCH) I 21,302 (Apr. 26, 1977). In addition, the administration of licensure laws, restrictions on corporate practice in professional areas, and the functioning of health planning agencies and professional standards review organizations are all on the FTC agenda.

276. See text accompanying notes 4-44, 139-48 supra.

277. See Note, The Role of Prepaid Group Practice in Relieving the Medical Care Crisis, 84 HARV. L. REV. 887, 955-56 (1971). 
the pressure for cost containment. ${ }^{278}$ Even though the profession has ultimately sponsored things that the public has wanted, the conditions it has imposed have always denied the public many options and have served providers' interests at least as much as consumers'. In each case, the profession's collective concessions have served to define and to legitimize a new line of defense and to restore the profession's united front just when it was in some danger of crumbling. With its public positions once again defensible, all of the profession's formidable powers of self-defense-its public prestige, its esprit de corps, its ethical codes, its all-embracing self-regulatory machinery and its ability to maintain internal discipline-could then be brought to bear with apparent legitimacy. The antitrust laws, concerned as they are with economic freedom, aggregations of private power and consumer welfare, should surely have something to say about strategies that physicians acting in concert devise in defense of their economic interests.

\section{A. Professionally Sponsored Prepayment Plans.}

In examining the market prospects for HMOs, this writer once concluded that professionally controlled Blue Shield plans were probably not "a very substantial obstacle to emergence of a satisfactorily competitive health care marketplace."279 This assessment must now be revised in view of, first, the failure of HMOs to become a substantial competitive force and, second, the somewhat pessimistic conclusion reached above about the ability of antitrust rules on boycotts and related restraints to maintain an environment adequately conducive to private innovation. The existence of profession-sponsored prepayment plans seems indeed to be an "obstacle to emergence of a satisfactorily competitive health care marketplace." Moreover, there would seem to be some prospect for applying the Sherman Act to remove professional control of Blue Shield plans where it still exists. ${ }^{280}$

The McCarran-Ferguson Act's exemption from the antitrust laws of "the business of insurance"281 surely provides no warrant for organized medicine to enter that business. The implications for competition and innovation of allowing an industry cartel to dominate the business of insuring against the need for the industry's services are too great to be ignored, and the usual policy of construing antitrust exemptions nar-

278. See text accompanying notes 58-61 supra. For an analogous professional move to preempt a market opportunity seized by a would-be innovator, see note 211 and accompanying text.

279. Havighurst, HMOs, supra note 1 , at 772.

280. The FTC's possible interest in seeking such a result appears in recent congressional testimony by Chairman Pertschuk. See note 139 supra.

281. See notes 129-30 supra and text accompanying notes 123, 129-30 supra. 
rowly would appropriately apply to this question. A recent district court decision in Ohio appears to have accepted an argument similar to that made here, refusing to extend the McCarran exemption to a medical society alleged to dominate a Blue Shield plan and to have used it for its own purposes. ${ }^{282}$

A possible defense for some Blue Shield plans is that state law has given the profession a warrant to offer its own service plan. ${ }^{283}$ This defense would seem to be greatly narrowed, however, by the Supreme Court's refusal in Goldfarb to recognize professional activity as exempt state action unless it is compelled, not simply authorized or "prompted," by state law. ${ }^{284}$ A state Blue Shield law merely authorizing creation of professionally dominated service plans would probably not now shield such plans from antitrust scrutiny. ${ }^{285}$ If the plan could not continue lawfully under state law without continued professional control, it could be liquidated by the antitrust court unless the state acted to lift the restriction.

Application of the rule of reason to professional sponsorship of prepayment plans could well yield the following conclusions in view of the plan's influence over physicians' fees and the record of Blue Shield's part in consolidating professional domination of private thirdparty payers: The potential harms flowing from one plan's special status as the medical profession's chosen instrument are substantial; all of the undeniable benefits of physician-sponsored prepayment plans could be derived through independent insurance plans or other prepayment mechanisms; policing the profession's conduct toward competing insurers and other innovative plans and toward physicians inclined to cooperate in innovative ventures is an inadequate protection of competitive values for all the reasons elaborated in earlier discussion. The

282. Ohio v. Ohio Medical Indem., Inc., 1976-2 Trade Cases \$ 61,128 (S.D. Ohio 1976). The Blue Shield plan itself was dismissed as a defendant, however, because its practices, even if influenced by the medical society, were held to be part of the "business of insurance" under the McCarran Act. Id. at 70,112. Such reasoning might be deemed unduly formalistic, and the dismissal might unduly complicate remedial measures. For another line of attack on physician domination of financing vehicles, see Ballard v. Blue Shield, 543 F.2d 1075 (4th Cir. 1976), cert. denied, 430 U.S. 922 (1977).

283. See, e.g., State Medical Soc'y v. Commissioner of Ins., 70 Wis. 2d 144, 233 N.W.2d 470 (1975).

284. 421 U.S. at 791.

285. Although a significant state legislative policy-the belief that service benefit plans were acceptable if, and perhaps only if, controlled by professional interests-would be overridden by the antitrust attack on professionally controlled plans, the federal action does not directly challenge the validity of state law itself but only the private initiative voluntarily taken under it. As the Supreme Court said in Parker v. Brown, 317 U.S. 341, 351 (1943), "[A] state does not give immunity to those who violate the Sherman Act by authorizing them to violate it, or by declaring that their action is lawful." 
ultimate conclusion of such an analysis would be that professional control of a substantial prepayment plan violates section 1 of the Sherman Act. For the reasons next discussed, this conclusion would hold even if professional control appeared to result in greater doctor cooperation with cost-containment efforts.

\section{B. Professionally Sponsored Cost Containment.}

The antitrust status of FMCs has yet to be tested, though some years ago the thesis was advanced that they could not stand under a Sherman Act analysis. ${ }^{286}$ This was and still is a surprising conclusion because foundations are dedicated to lowering costs and improving quality and have been shown to have some beneficial effects. ${ }^{287}$ Nevertheless, it can be argued that FMCs are a device for curbing the excesses of some physicians as a means of maintaining the monopolies and profits of the cartel members as a group against new competition and/or government intervention. Although FMCs may in fact succeed in lowering health care costs, they cannot be expected to duplicate the results of maintaining a competitive market, and the entry-limiting price level they maintain, though responsive in fact to potential competition from HMOs and other innovators, will be higher than a competitive price. The same argument would apply to any professionally controlled plan or initiative that asserted its effectiveness in cost containment as a defense.

Under the procompetitive premise of the antitrust laws, FMCs and similar initiatives should be recognized as part of a profit-maximizing strategy of a coalition of monopolists. Case law suggesting that the fixing of maximum prices is regarded no more favorably than minimum-price fixing would seem appropriately invoked to curb private price regulation undertaken by a cartel. ${ }^{288}$ In many market circumstances, an FMC could be challenged as an exclusionary tactic of a monopolist ${ }^{289}$ or as the product of a conspiracy to monopolize the pro-

286. Havighurst, HMOs, supra note 1, at 767-77; Havighurst, Speculations, supra note 1, at 257-63. For a brief description of the foundations, see text accompanying notes 58-61 supra.

287. See, e.g., Edgahl, Taft, Friedland \& Linde, supra note 59. But their achievements are considerably less impressive than those of independent HMOs. See, e.g. , Gaus, Cooper \& Hirschman, supra note 59.

288. See Albrecht v. Herald Co., 390 U.S. 145 (1968); Kiefer-Stewart Co. v. Joseph E. Seagram \& Sons, Inc., 340 U.S. 211 (1951). Both cases involved so-called vertical restraints whereby a seller sought to limit the resale prices of his customers. The illegality of a horizontal restraint on maximum prices would seem to follow a fortiori in view of the anticompetitive, entry-limiting purpose and effect. The elements of coercion, of assumed extragovernmental power and restriction on the "freedom of traders," id. at 213 , are the same in either case.

289. If HMOs had a substantial market share, a monopolization charge against the physician organizers of an FMC under $\S 2$ of the Sherman Act, 15 U.S.C. $\S 2$ (1976), might fail unless 
vision of medical care. ${ }^{290}$ The most likely theory of attack on FMCtype efforts, however, would be under section 1 of the Sherman Act as a combination in restraint of trade lacking virtues sufficient to redeem its several anticompetitive features. ${ }^{291}$ Although in both the HMO and PSRO legislation Congress has been highly tolerant of professionally dominated reforms, no explicit antitrust exemptions appear in those laws, and it is not difficult, using established rules of statutory construction, to give effect to these enactments without disturbing overriding antitrust principles. ${ }^{292}$ The fundamental premise of the antitrust laws, which can be contested in a legislative but not in a judicial forum, is that the competitive solution is always preferable to the cartel's.

While it seems superfluous to elaborate all of the legal arguments here, it is worth noting several ways in which the analysis in this Article strengthens the case for curbing organized medicine's endeavors to get its house in order and thereby to maintain its essential dominance. Previously, it was arguable that the FMC might have a role as an appropriate response by an otherwise disorganized fee-for-service sector to competition from independent HMOs actually present in the marketplace. Thus, it was noted that "an essential item of proof in establishing the antitrust defense of the FMC is a showing that insurers are unable or unwilling to take on the job." ${ }^{293}$ This Article has already concluded,

insured fee-for-service medicine were treated as a separate relevant market and HMO care as an imperfect substitute. Even then, the court's natural tendency would be to look at the FMC's market share rather than the share of its sponsors. One could anticipate difficulty in persuading a court to view a strategy preserving and strengthening the natural monopoly power of a large number of independent practitioners, see note 174 supra, as monopolizing conduct. See Havighurst, HMOs, supra note 1, at 776-77 \& n.181.

290. Market definition appears to be less of a problem in $\$ 2$ attempt or conspiracy cases than in monopolization cases. Turner, Antitrust Policy and the Cellophane Case, 70 HARv. L. REv. 281, 303-08 (1956).

291. The theory is developed in Havighurst, HMOs, supra note 1, at 767-77; Havighurst, Speculations, supra note 1, at 257-63.

292. First, the HMO Act, 42 U.S.C. $\$ \S 300 \mathrm{e}$ to $300 \mathrm{e}-15$ (Supp. V 1975), as amended by Pub. L. No. 94-460, 90 Stat. 1945 (1976), contemplates "individual practice associations" (IPAs), id. § $300 \mathrm{e}-15$, and the expectation was undoubtedly that many of these would be under professional sponsorship, following the FMC model. The law provides no explicit endorsement of such plans, however, and IPAs may be established by other interests. There is nothing in the law to prevent antitrust from supplying the means of keeping the useful IPA vehicle, see text accompanying note 114 supra, out of organized medicine's control. Second, although the PSRO law, 42 U.S.C. $\S \S$ 1320c et seg., (Supp. V 1975), enfranchises professionally dominated review organizations, it gives them no mandate outside the realm of federally financed care, which presents special problems. Construing these laws in the light of the general principle that repeal of the antitrust statutes by subsequent specific regulatory enactments will not be implied unless necessary to make the regulatory statute work, see, e.g., Silver v. New York Stock Exch., 373 U.S. 341 (1963), leaves antitrust a major role in structuring the financing system and curbing abuses of professional self-regulatory powers.

293. Havighurst, Speculations, supra note 1, at 259. 
however, that this is not a matter reliably subject to proof, that insurer testimony is self-serving, and that the means are readily available for insurers to compete effectively in cost containment. This availability of alternative means of solving the problems that FMCs purport to address means that the FMCs' alleged benefits are entitled to little weight in the balancing process.

Another reason for taking an even harder line against professionally sponsored reforms than that previously advocated is that HMOs seem unable by themselves to supply the competition needed to obviate concern about the FMC's monopoly of fee-for-service medicine. The earlier commentary, which strongly praised HMOs, was written before Congress undertook to regulate HMOs heavily in the name of helping them and was based on a faith that the HMO movement would be allowed to flourish, a faith that has been largely unrewarded. ${ }^{294}$ In only a handful of local markets have HMOs proven effective enough as competitors to allow the FMC to be perceived as a competitive response rather than as an exclusionary maneuver. ${ }^{295}$

Finally, the analysis in this Article should heighten the concern that the availability of an FMC or some other token of the medical profession's apparent commitment to internal reform makes the profession's concerted resistance to innovative alternatives substantially more effective and more difficult to contest under antitrust principles than it would otherwise be. The antitrust effort to loosen organized medicine's domination of its economic environment is unlikely to succeed unless it can frustrate the profession's efforts to implement its own halfway measures as solutions to the problems that the public comes to per-

294. See, e.g., Kissam, supra note 3, at 492-99.

295. See generally Federal Trade Commission, Staff Report on the Health Maintenance ORganization and Its Effects on Competition (1977). The Minneapolis-St. Paul area, with six substantial independent HMOs actively serving the area and growing rapidly, $i d$. $37-44$, is one in which the FMC can perhaps be seen as simply one more competitor. The following report indicates the pressure under which the FMC operates:

In order to cut hospital costs, the Minneapolis Physicians Health Plan, an individual practice association model HMO sponsored by the Hennepin County Medical Society, has sent a letter to its 1,000 participating physicians indicati[ng] that overuse of hospital facilities is a "major, continuing abuse" that increases the cost of medical care. According to Russell Wilson, executive director, the plan is conducting pre-admission reviews, concurrent reviews for length of stay, and retrospective reviews to monitor changes and medication, develop physician profiles and identify problem areas. The new measures are necessary if the plan is to remain competitive with the six other HMOs operating in the Twin Cities area, and if the plan is to become self-sustaining. "If we could cut one day from the average length of stay in hospital, we could make the plan workable," according to Wilson.

HMO \& Health Services Rep. 9-10 (July 1977). Despite an appearance of dramatic change that reduces concern about the FMC, prospects might be better for even more substantial changes if the medical society could not operate its own plan. It is still not clear why, even in Minneapolis, the fee-for-service practitioners should be allowed a chosen instrument of self-defense. 
ceive. $^{296}$

Whatever the outcome of the technical antitrust analysis of FMCs and other professionally dominated reforms, the substantive concerns raised in this discussion may be reflected in regulatory decisions and policy planning in the health care system. Thus, certificates of need might be denied to FMC-type HMOs on the express ground that they are monopolistic strategems designed to foreclose more substantial change. ${ }^{297}$ Already, in Massachusetts, an FMC-type HMO has encountered antitrust-related arguments in seeking needed approval from the insurance department. ${ }^{298}$ Although it may be expecting too much, alerting the Department of Health, Education and Welfare, state and 10cal health planning bodies, and other health system regulators and decisionmakers to the anticompetitive hazards of FMCs and similar professional initiatives may take some of the burden off of the antitrust

296. Needless to say, the argument in this Article directly contradicts the philosophy underlying current proposals to encourage professional and hospital interests to control rising costs. See note 61 supra. Though the proposal for voluntary cost containment was developed with the antitrust laws very much in mind, it should still be held offensive to antitrust policy. The program as outlined, see Letter, supra note 61, would rely for sanctions not on professional or commercial boycotts or other coercive measures but on public pressures brought to bear through a certification or seal-of-approval program. Nevertheless, the proposal would strengthen the medical profession's and hospitals' solidarity with respect to other cost-containment measures that might be taken. The objective of reducing the rate of hospital cost increases by two percentage points in each of two years would be held out as all the public is entitled to, and other attempts at cost containment would be held in abeyance while the profession and the hospitals seek to demonstrate their good faith. In addition, it seems unlikely that the mechanisms for effectuating the desired voluntary cost containment could avoid facilitating the allocation of markets and the discussion of prices and other elements normally left to competition.

297. See Havighurst, supra note 65.

298. See Controversy Swirls Around Bay State HMO, NAT'L UNDERWRITER, Apr. 15, 1978, at 23; IPA Hit With Antitrust Charge, Worid News, Apr. 17, 1978, at 8; "Open" HMOs Await Massachusetts Licenses, NAT'L UNDERWRITER, Feb. 11, 1978, at 1. From press accounts, the IPA (an FMC-type plan) appeals to doctors as a means of combatting recent cost-containment measures undertaken by Blue Shield in Massachusetts. See text accompanying note 113 supra. The antitrust challenge goes primarily to the price-fixing concern raised by the use of a usual and customary fee schedule, see Kallstrom 654-59, market division by the several IPA plans in the state, and use by these plans of a joint selling agent. Nevertheless, concern about the effect on Blue Shield would also be warranted. The insurance department had raised issues concerning the plan's ability to meet its commitments for the premium to be charged, suggesting that the case may involve below-cost disciplinary pricing designed to bully Blue Shield into line just as earlier discussion suggested may have occurred in the Oregon State Medical Society case. See text accompanying notes 54-57 supra.

The press accounts do not reveal whether the IPAs in Massachusetts are controlled by professional societies or are independently sponsored or whether they have received the societies" "seal of approval." It is at least possible that a plan could become the profession's "chosen instrument" without such control or explicit endorsement. But in such cases, the plan's role in carrying messages and assurances back and forth among practitioners and providing the service of organizing the cartel might lead to a finding of conspiracy under Interstate Circuit, Inc. v. United States, 306 U.S. 208 (1939). 
enforcers and widen acceptance of their assumption of a role in health sector developments.

\section{The Medical Societies as Collective Bargainers.}

A further implication of the analysis in this Article is that professional organizations are, or can readily be, prohibited from engaging in negotiations with health insurers, unions, employers and other consumer groups over the nature and details of financing arrangements. While overt bargaining over fees has been generally eschewed because of the antitrust problem, ${ }^{299}$ informal bargaining over other terms of dealing has occurred without recognition that concerted action on such matters also raises antitrust issues. ${ }^{300}$ The prohibition against collective bargaining over such matters as an insurer's second-opinion requirement would appropriately apply to the medical society even if the negotiations were initiated by the insurer. ${ }^{301}$ Moreover, the insurer implementing a deal negotiated with the medical establishment may itself be guilty of at least a technical infraction as a co-conspirator.

The underlying reason why negotiations between insurers and professional organizations have occurred (indicating the reason why they should be foreclosed) is the implicit threat of boycott or related difficulty facing any plan that departed from accepted practice without first securing professional approval. Although private advice may be available from the medical society, there should no longer be any necessity for negotiating the terms of cost-containment initiatives. Removing the local medical societies from their accustomed role will seem counterproductive to some in view of certain beneficial changes that have been introduced as a direct result of insurer-provider negotiations in the past. But, as in the case of the benefits flowing from FMCs, these improvements are probably minor compared to what would be achieved by independent third parties negotiating with individual providers in the absence of the boycott threat.

Health care providers' practice of combining for the purpose of bargaining with third-party payers has a venerable history, giving it an apparent legitimacy that seems to argue for its continuation. The prac-

299. See Kallstrom 661-62, discussing the distinction between individually negotiated and collectively negotiated fees in a variety of contexts involving prepayment for professional services.

300. See L. Sullivan, supra note 212, at 285-89. Sullivan notes that the absence of pricefixing removes the case from coverage by any per se rule. Nevertheless, utilization is at least as sensitive an item as price in competitive bargaining in health care, and courts should not hesitate to extend per se concepts to this case.

301. Kallstrom elucidates this principle in the context of fee-setting by insurers. Kallstrom 661. Although IPAs can be created by private health insurers and other interests, few have been begun without specific approval of the local medical society. 
tice was obviously inherent in the original status of Blue Cross and Blue Shield plans as creatures of provider organizations, and bargaining between such plans and providers was inconsequential as long as the service plan was already charged with serving providers' collective interests. But, as some Blue plans came to be more independent, facing competition on the one hand and the demands of consumers and regulators on the other, the bargaining process became more intense. Nevertheless, given the gradualness of the evolution away from strict provider control, it probably never occurred to anyone that providers should be negotiated with only individually and not collectively. In any event, there was usually no explicit agreement on actual prices to be charged or paid; rather, they varied with costs or circumstances and were handled either by a cost-related formula (in the case of hospitals) or by reference to usual and customary fees or charges. ${ }^{302}$ Thus, the most obvious antitrust concern-price-was not aroused, and it was possible to see other issues, such as cost-containment measures, merely as questions of ethics and administrative detail.

Bargaining between the Blues and organized providers has had more than just historical acceptance behind it. The special relationship with providers is expressly recognized in many state laws. ${ }^{303}$ Moreover, the McCarran-Ferguson Act and state regulation have long pushed antitrust issues far into the background. Further, the Blue plans have become very large in many places, giving rise to a need on the part of providers to organize to protect themselves against potential exploitation once their direct control was weakened. Indeed, insurance commissioners in some states have leaned heavily on the Blues in an attempt to use their monopsony power in just this way, producing confrontations that are as much political as economic and therefore seem to make a collective industry response appropriate. ${ }^{304}$ It would be unfortunate if the antitrust laws were applied to deny self-help to provid-

302. See Kallstrom.

303. See, e.g., State Medical Soc'y v. Commissioner of Ins., 70 Wisc. 2d 144, 233 N.W.2d 470 (1975).

304. See Travelers Ins. Co. v. Blue Cross, 481 F.2d 80 (3d Cir. 1973); Frankford Hosp. v. Blue Cross, 417 F. Supp. 1104 (E.D. Pa. 1976), affd per curiam, 554 F.2d 1253 (3d Cir.), cert. denied, 434 U.S. 860 (1977); Doctors, Inc. v. Blue Cross, 431 F. Supp. 5 (E.D. Pa. 1975), affd per curiam, 557 F.2d 1001 (3d Cir. 1976). For the interpretation that the application of the McCarran exemption in these cases reflected the Insurance Commissioner's active involvement, see Royal Drug Co. v. Group Life \& Health Ins. Co., 556 F.2d 1375, 1382-83 (5th Cir. 1977), cert granted, 98 S. Ct. 1488 (1978). See also note 131 supra. In all of these cases, the providers engaged in collective bargaining with Blue Cross, and, in Travelers, the court alluded approvingly to this fact in answer to the plaintiff's claim that Blue Cross used "coercion" against the hospitals. 481 F.2d at 84. 
ers confronted by a state-created and state-maintained monopsonist. ${ }^{305}$

The problem faced by the antitrust enforcement agencies and the courts is to find ways of breaking down providers' united front toward third-party innovations in financing and delivery wherever collective bargaining cannot be justified as a legitimate exercise of political or countervailing economic power. This is a complex undertaking, but one incisive and effective stroke would be to apply antitrust principles to sever providers' relationships with the Blues once and for all, converting the Blues into independent third parties ${ }^{306}$ and perhaps splitting some of them into smaller units to reduce their market power. An alternative would be to recognize the Blues' special status in the community and their special relationship to providers by allowing collective bargaining with them while at the same time protecting the right of commercial insurers, unions, employers and other consumer-operated plans to negotiate with providers individually. However appealing this less radical approach may seem, it runs the risk that the Blues would remain (or become) the providers' chosen instruments, with results similar to those in the Oregon State Medical Society case. While the political pressures bearing on the Blue plans might prevent this from occurring, they have apparently not done so yet, since commercial insurers seem unable to go much beyond the Blues in their cost-containment endeavors. Moreover, the Blues' apparent status as models for insurer behavior flows directly from collective bargaining, which by conferring legitimacy on mild cost-containment efforts makes any more aggressive efforts appear illegitimate because not professionally validated. For these reasons, it seems highly desirable to put the Blues on the same footing as everybody else, treating them more like private insurers and less like political instrumentalities.

Although a Blue plan or a large buying group might wield monopsony power in some communities, that problem could be dealt with on an ad hoc basis wherever specific abuses appeared. Buyer coalitions should be controlled by antitrust principles, too, but in the present climate pragmatism suggests some tolerance for consumer self-help measures taken against a background of past abuses by providers and the demonstrated stubbornness of the medical monopoly. ${ }^{307}$

305. See notes $122,131-33,232-33$ supra and accompanying text.

306. See Pertschuk Testimony, supra note 139.

307. See note 121 supra. 


\section{ConClusion}

This Article has argued that clarification and enforcement of the responsibilities under the antitrust laws of medical societies, hospital staffs and other organizations of competing physicians would have the benefit of significantly increasing opportunities for medical care costcontainment measures by third-party payers and other would-be innovators in the health care system. The potential magnitude of the benefits that would flow from a stronger antitrust effort remains open to question, however, for several reasons. Certainly antitrust enforcers and the courts can never be as single-minded as the academic observer, and, as has been seen, many practical as well as doctrinal problems would beset any effort to change the health world dramatically with antitrust weapons. Moreover, professional restraints alone cannot account for the deep-seated reluctance of real-world health insurers and their customers to pursue aggressively many of the cost-containment strategies that are available. Such interest in cost containment as does exist among insurance purchasers may not be sufficient under current circumstances to induce all the private innovation needed to satisfy the public clamor for cost control. Although health insurers are revealing increasing cost awareness, they may be responding as much to political as to market pressures.

The contrast between weak private interest in undertaking major cost-containment innovation and public dismay over rising costs practically compels the conclusion that the tax laws' unlimited treatment of health insurance as a tax-free fringe benefit, weakening private costcontainment incentives, is a powerful force behind the market failure for which public remedies are frantically being sought. Yet, despite this fundamental distortion, there would seem to be enough signs of an awakening private interest in health care costs to justify using antitrust tools to give the private sector a chance to show what it can yet do, even operating at the artificial margin which the tax laws dictate. Even though private efforts would be very much diluted without a change in the tax laws, that would seem to be an argument for changing those laws, not for giving up on the private sector and attempting to solve the problem by pervasive regulation. If the tax laws could be changed and antitrust enforcement were reasonably effective, then a strong argument could be made that any level of cost containment that was achieved, even if it disappointed expectations, was as close to the social optimum as we could hope to come. The private market would then serve as a useful yardstick for public programs, something that it has heretofore failed to do. 
The movement for some kind of national health insurance program will in due course result in a major federal initiative designed to put the health care system on a firmer track, and certainly, in view of the inequities in the present system and its poor overall performance, some federal initiative is required. Although it has long been acknowledged that one option available to the government is to foster a system controlled to a significant degree by market forces, that option has never been explored with the same vigor as regulatory alternatives. Nevertheless, one recent proposal for national health insurance has focused attention more sharply than ever before on the possibilities for building on the private sector's strengths by facilitating consumer choice among a variety of competing health care plans under conditions fostering competition based on price as well as the plans' other features. The so-called "Consumer-Choice Health Plan," formulated by Professor Alain Enthoven, ${ }^{308}$ depends heavily on changing the tax laws to strengthen consumer cost consciousness and on the use of vouchers to give the low-income recipients of extra federal subsidies the means of shopping in a competitive marketplace. Although the Enthoven plan contemplates more regulation than may be needed to achieve the desired objective - particularly in limiting the opportunities for redesigning insurance benefit packages along the lines suggested in this Article ${ }^{309}$-it convincingly sets forth the rationale for relying on private rather than public decision makers to restructure the health care financing and delivery system.

The Enthoven plan or any other market-oriented health policy would require an effective antitrust enforcement strategy ${ }^{310}$ to maintain not just the appearance of choice in a pluralistic environment but the reality of a marketplace in which private financing and delivery mechanisms of all kinds could compete for consumers' dollars. Competition

308. See Enthoven.

309. Enthoven says only this:

Any plan for national health insurance must include definitions of covered benefits and eligible persons. The choices are largely political judgments . . . . The philosophy of CCHP [Consumer-Choice Health Plan] suggests that, beyond the essentials that must be specified by law, what is included in health benefits plans should be determined by the consumer desires expressed in the marketplace, rather than by provider interests.

Id. 714. It is not clear why Enthoven believes that benefit packages are a political question, in view of the arguments for precision and selectivity in coverage, see text accompanying notes 82-93, 134-35 supra, and evidence that individuals have widely different preferences and needs for financial protection, see, e.g. , Havighurst, supra note 85 . Either he has bowed implicitly to the political considerations or he believes that the HMO model, using provider incentives, is sufficiently promising in both the short and long run to permit foreclosure of the kinds of innovation needed to make insured fee-for-service medicine cost-effective.

310. See Enthoven 716, for a brief but thoughtful acknowledgment of antitrust's role. See also Ehrbar, A Radical Prescription for Medical Care, FoRTune, Feb. 1977, at 164. 
must permit plans to offer a meaningful variety of combinations of the elements that consumers and providers may regard as important in a health plan, including its cost, the quality of care and amenities provided, the character of the doctor-patient relationship fostered, the utilization controls employed, and the scope of coverage and financial protection, particularly the choice between comprehensiveness of benefits and greater self-insurance for noncatastrophic risks. This Article has sought to demonstrate that the overriding objective of antitrust policy in the health services sector must be to curb the medical profession's traditional dictation to third parties on the subjects of financing mechanisms, cost containment and organizational reforms responding to consumers' preferences. On such issues, the organized medical profession, despite its many honorable achievements and inclinations, cannot escape a severe conflict of interests that makes it an inappropriate spokesman for patients' interests and, in particular, an unreliable authority on the complex trade-offs between cost and the style, intensity, place and quality of medical care. The antitrust laws embody a long-standing general policy recognizing consumers as the best decisionmakers on such issues.

Though only recently recognized as a major factor in health sector developments, the antitrust laws have in fact played a significant part in the evolution of the health services industry and the emergence of its current problems. The practices and power structure through which the medical profession now controls its economic environment are in large measure a reflection of antitrust's default during the era when federal law based on the commerce power could not reach local restraints and when the "learned professions" were assumed to have a special right to police their own domains. Moreover, although the Supreme Court has had only two occasions to address the antitrust laws' application to developments in health care financing, those two cases-the $A M A$ case, vindicating HMOs, and the Oregon State Medical Society case, seemingly legitimizing doctor-sponsored health insurance as the profession's "fighting ship"-shaped much of the framework for subsequent policy developments. Thus, it is no accident that we have perceived HMOs, the one innovation that slipped through the medical profession's defenses, as the only alternative to traditional, hands-off prepayment mechanisms and have neglected the many other approaches to financing and delivery that lie on the unexplored spectrum between prepaid group practice on the one hand and traditional insurance and service plans on the other. This Article has sought to document the belief that it is not too late, if we could count on a small amount of governmental leadership, to make up for past failures of antitrust law and policy, to 
expand the range of perceived health policy options and to stimulate promising private experimentation and change addressed to the cost problem. As a uniquely American institution, the antitrust laws may be the distinguishing feature that gives the United States, alone in the world, the option of relying more on the private sector than on government to make its health care system operate in the public interest. 
. 